\title{
Two decades of ethnobotanical research in Southern Ecuador and Northern Peru
}

\author{
Rainer W. Bussmann* \& Douglas Sharon
}

\begin{abstract}
This paper is the compiltion of a talk given during the "Advanced Topics in Ethnobiology 2013" workshop in Recife, Brazil, under the title "A decade of ethnobotany in Northern Peru - healers and markets, bioassays, paleobotany and considerations of the Nagoya Protocol" Northern Peru represents the "Health Hub" of the Central Andes, with roots going back to traditional practices Cupisnique culture (1000 BC). During almost two decades of research semistructured interviews with healers, collectors and sellers of medicinal plants, and bioassays to evaluate the effective and plant toxicity were carried out. Most (83\%) of the 510 species used were native to Peru. $50 \%$ of the plants used in colonial times disappeared from the pharmacopoeia. Common and exotic plants were mostly used for common ailments, while plants with magical purposes were only employed by specialist healers. About 974 preparations with up to 29 ingredients treated 164 conditions. Almost $65 \%$ of the medicinal plants were applied in mixtures. Antibacterial activity was confirmed in most plants used for infections. The aqueous extract $24 \%$ and $76 \%$ ethanolic extracts showed toxicity. Traditional preparation methods take this into account when choosing the appropriate solvent for the preparation of a remedy. The increasing demand did not increase the significant cultivation of medicinal plants. Most plants are wild-collected, causing doubts about the sustainability of trade. Dedicated programs aim to establish in-situ collections of important species, as well as to repatriate traditional knowledge in local language, under the guidelines of the Nagoya Protocol.
\end{abstract}

Keywords: William L. Brown Center, Traditional knowledge, ethnobotany, ethnopharmacology, Nagoya Protocol, repatriation of knowledge

\section{INTRODUCTION}

William L. Brown Center (WLBC) at Missouri Botanical Garden and its role in Traditional Medicine

\section{WLBC}

Plants provide humankind with our most basic resources - food, medicines, fibre, and a whole array of other useful products. Relatives of wild crops and traditional varieties - the repository of genetic diversity within and among food plants - have been the foundation of crop domestication, plant breeding, and indeed the modern agriculture that feeds the earth's 6 billion people. Plants provide the molecular basis of many pharmaceuticals, as direct compounds or molecular blueprints. Modern science begins to confirm that the distinction between nutrition and medicine is blurred. With economic development empowering a greater percentage of the world's people, urban areas continuing to expand, and human populations projected to double in the next 50 years, it seems certain that natural resources will

1 William L. Brown Center, Missouri Botanical Garden, P.O. Box 299, St. Louis, M0 63166-0299, USA; phone: (314) 577-9503, facsimile: (314) 577-0800; * corresponding author, e-mail: rainer.bussmann@mobot.org 
face increasing threat. Habitat loss, unsustainable extraction of plants, spread of invasive species, climate change, and other human activities will have tremendous impact. Plant species will be lost, genetic diversity of surviving species will be diminished, and traditional knowledge associated with plant use will be eroded. Perhaps never before in human history has there been a more pressing need to discover, understand, conserve and sustainably use the plant resources that are essential for the benefit of humanity.

The William L. Brown Center is uniquely positioned to respond to these issues and to play a leading role in addressing the problems outlined above. The Center is located in one of the largest herbaria in the world, making a wealth of plant data available from collections. Access to advanced scientific methodologies allows more rapid characterization of useful species, chemicals or genes that lead to new nutritional and pharmaceutical products. The Center has access to improved information technologies that facilitate the rapid communication of data, and allow repatriation of data to the countries where it is needed to make intelligent decisions about the use of natural resources. Appropriate partnerships between the Center and collaborators in developing countries enable capacity building to ensure that countries have the infrastructure to make sound development and conservation plans. Finally, partnerships between the Center and both national institutions and local communities permit the implementation of integrated conservation and sustainable development programs.

WLBC focuses to a large extent on mountainous ecosystems. Mountain systems are highly biodiverse, they are the most important sources of crop species and medicinal plants, and are heavily affected by climate-change. The programs of the WLBC concentrate on medicinal and food species in mountain regions, especially the Andes, the Himalayas and the African Highlands. Numerous projects utilize information from local people to better understand how communities rely on locally available natural resources and to design solutions so that they can be used sustainably. The WLBC ethnobotany programs are internationally recognized as leading scientific efforts to understand the relationship between plants, people, the environment, and associated traditional knowledge. WLBC is a leader in the compilation of databases on traditional medicinal and food species. The center plays a leading role in the preservation of traditional knowledge for indigenous and local communities, and in the production of useful plant volumes for ongoing floristic projects. The Center plays a leading role organizing symposia, meetings, and workshops to facilitate scientific exchange. The Garden is an international leader in developing the legal and ethical frameworks for conducting international programs in natural products discovery, medicinal plant research, and ethnobotany. These frameworks ensure compliance with the Convention on Biological Diversity and equitable distribution of benefits that arise from such research, including efforts to value, acknowledge and equitably compensate traditional knowledge. Projects conducted by the WLBC include training programs ranging from botanical field techniques and ethnobotanical research to collections management, market development, sustainable production and public health. Projects have significant conservation components and these activities include programs aimed at medicinal and other useful plants as well as those that incorporate traditional knowledge in the conservation of natural resources.

\section{Traditional Medicine}

Traditional Medicine is used globally and has a rapidly growing economic importance. In developing countries, Traditional Medicine is often the only accessible and affordable treatment available. In Uganda, for instance, the ratio of traditional practitioners to the population is between 1:200 and 1:400, while the availability of Western doctors is typically $1: 20,000$ or less. Moreover, doctors are mostly located in cities and other urban areas, and are therefore inaccessible to rural populations. In Africa, up to $80 \%$ of the population uses Traditional Medicine as the primary healthcare system. In Latin America, the WHO Regional Office for the Americas (AMRO/ PAHO) reports that $71 \%$ of the population in Chile and $40 \%$ of the population in Colombia have used 
Traditional Medicine. In many Asian countries Traditional Medicine is widely used, even though Western medicine is often readily available. In Japan, $60-70 \%$ of allopathic doctors prescribe traditional medicines for their patients. In China, Traditional Medicine accounts for about $40 \%$ of all healthcare, and is used to treat roughly 200 million patients annually. The number of visits to providers of Complementary-Alternative Medicine (CAM) now exceeds by far the number of visits to all primary care physicians in the US (WHO 1999a,b; 2002).

Complementary-Alternative Medicine is becoming more and more popular in many developed countries. Forty-eight percent of the population in Australia, $70 \%$ in Canada, $42 \%$ in the US, $38 \%$ in Belgium and $75 \%$ in France, have used Complementary-Alternative Medicine at least once (WHO 1998; Fisher et al. 1971; Health Canada 2001). A survey of 610 Swiss doctors showed that $46 \%$ had used some form of CAM, mainly homeopathy and acupuncture (Domenighetti et al. 2000). In the United Kingdom, almost $40 \%$ of all general allopathic practitioners offer some form of CAM referral or access (Zollmann et al. 2000). In the US, a national survey reported the use of at least 1 of 16 alternative therapies increased from $34 \%$ in 1990 to $42 \%$ in 1997 (Eisenberg et al. 1998; UNCTD 2000).

The expenses for the use of Traditional and Complementary-Alternative Medicine are exponentially growing in many parts of the world. In Malaysia, an estimated US $\$ 500$ million is spent annually on Traditional Medicine, compared to about US $\$ 300$ million on allopathic medicine. The 1997 out-of-pocket Complementary-Alternative Medicine expenditure was estimated at US \$ 2,700 million in the USA. In Australia, Canada, and the United Kingdom, annual ComplementaryAlternative Medicine expenditure is estimated at US $\$ 80$ million, US $\$ 2,400$ million and US $\$ 2,300$ million, respectively. The world market for herbal medicines based on traditional knowledge was estimated at US $\$ 60,000$ million in the late 1990s (Brevoort 1998). A decade later it was around US \$ 60 billion (Tilbert et al. 2008) with estimates for 2015 at US $\$ 90$ billion (GIA 2012). The sales of Herbs and herbal nutritional supplements in the US increased 101\% between May 1996 and May 1998. The most popular herbal products included Ginseng (Ginkgo biloba), Garlic (Allium sativum), Echinacea spp. and St. John's Wort (Hypericum perforatum) (Brevoort 1998).

Traditional and Complementary-Alternative Medicine are gaining more and more respect by national governments and health providers. Peru's National Program in Complementary Medicine and the Pan American Health Organization recently compared Complementary Medicine to Allopathic Medicine in clinics and hospitals operating within the Peruvian Social Security System. A total of 339 patients - 170 being treated with Complementary-Alternative Medicine and 169 with allopathic medicine - were followed for one year. Treatments for osteoarthritis; back pain; neurosis; asthma; peptic acid disease; tension and migraine headache; and obesity were analyzed. The results, with $95 \%$ significance, showed that the cost of using Complementary-Alternative Medicine was less than the cost of Western therapy. In addition, for each of the criteria evaluated - clinical efficacy, user satisfaction, and future risk reduction Complementary-Alternative Medicine's efficacy was higher than that of conventional treatments, including fewer side effects, higher perception of efficacy by both the patients and the clinics, and a $53-63 \%$ higher cost efficiency of ComplementaryAlternative Medicine over that of conventional treatments for the selected conditions (EsSalud 2000).

According to WHO (2002), the most important challenges for Traditional Medicine / Complementary-Alternative Medicine for the next years are:

- Research into safe and effective Traditional Medicine and Complementary Alternative Medicine treatments for diseases that represent the greatest burden, particularly among poorer populations.

- Recognition of the role of Traditional Medicine practitioners in providing healthcare in developing countries.

- Optimized and upgraded skills of Traditional Medicine practitioners in developing countries. 
- Protection and preservation of the knowledge of Indigenous Traditional Medicine.

- Sustainable cultivation of medicinal plants.

- Reliable information for consumers on the proper use of Traditional Medicine and Complementary-Alternative Medicine therapies and products.

Northern Peru represents the "health axis" of the old Central Andean cultural area stretching from Ecuador to Bolivia. The traditional use of medicinal plants in this region, which encompasses in particular the Departments of Piura, Lambayeque, La Libertad, Cajamarca, Amazonas, and San Martin possibly dates as far back as the first millennium B.C. (north coastal Cupisnique Culture) or at least to the Moche period (A.D. 100-800), with healing scenes and healers frequently depicted in ceramics.

Precedents for this study have been established by early colonial period chroniclers (Monardes 1574; Acosta 1590; Cobo 1653/1956; the plant collections (293 plants in crates 11 and 12 of 24) of Bishop Baltasar Jaime Martínez Compañón sent to the Palacio Real de Madrid along with cultural materials in 1789 under the title Trujillo del Perú in 9 illustrated volumes (Martinez Compañon 1789; Schjellerup 2009; Sharon et al. 2006); the travel journals of $\mathrm{H}$. Ruiz from 1777-88 (Ruiz 1777-1788); the work of Italian naturalist Antonio Raimondi (1857); ethnoarchaeological analysis of the psychedelic San Pedro cactus (Sharon 2000); curandera depictions in Moche ceramics (GlassCoffin et al. 2004), and research on the medicinal plants of Southern Ecuador (Bejar et al. 1997, 2001; Bussmann 2006; Bussmann \& Sharon 2007).

\section{ANTECEDENTS - MEDICINAL PLANT RESEARCH AND TRADITIONAL MEDICINE IN PERU}

Containing 78 of the 107 eco-regions of the world, in 1993, it was estimated that Peru had 17,143 taxa of spermatophytes in 2,485 genera and 224 families (Brako et al. 1993). It is thought that only $60 \%$ of the Peruvian flora has been studied, with 1,400 species described as medicinal (BrackEgg 2004).
The importance of biodiversity for the Peruvian economy is enormous since $25 \%$ of all exports are living species, the uses of which are essential to local populations in terms of firewood, meat, lumber, medicinal plants, and many other products. Of particular importance are vegetal species, with 5,000 plants applied in 49 different uses of. Of the 5,000 plants in use some 4,400 are native; only 600 are introduced. The majority of useful native species are not cultivated; only 222 can be considered to be domesticated or semidomesticated (Brack-Egg 1999).

Transculturation is resulting in an enormous loss of traditional knowledge of great value to the science and technology of Peru. The flora of the country represents $10 \%$ of the world's total, of which $30 \%$ is endemic. Peru is the fifth country in the world in number of plant species with known properties utilized by the population (4,400 species); it is the first in domesticated native species (182) (Brack-Egg 1999).

In all Peruvian ethnic groups, plant knowledge is invaluable because it reinforces national identity and values, which are being lost in the complementary processes of modernization and globalization. In the current situation the emerging recognition and incipient application of these resources and associated knowledge emphatically underscores the critical need for ethnobotanical research.

Over the last 15 years considerable progress has been made in the overall taxonomic treatment of the flora of Peru. However, while the Amazon rainforests have received a great deal of scientific attention, the mountain forests and remote highland areas are still relatively unexplored. Until the late 1990s little work had been done on vegetation structure, ecology, and ethnobotany in the mountain forests and coastal areas of the North. In spite of the fact that this region is the core of what Peruvian anthropologist Lupe Camino (1992/1999) calls the "health axis" of Central Andean ethnomedicine, little ethnobotanical and ethnomedical research has been published on the rich flora found here. 


\section{ISSUES IN THE GLOBALIZATION OF TRADITIONAL MEDICINE}

Moran, King and Carlson (2001) trace the emergence of biodiversity prospecting. On 5 June 1992 , in order to alleviate the loss of earth's flora and fauna the Convention on Biological Diversity (CBD) was inaugurated at the UN Earth Summit in Rio de Janeiro, Brazil. CBD objectives are: 1) conservation of biodiversity, 2) sustainable use of components of biodiversity, and 3) equitable sharing of benefits derived from commercial use of genetic resources.

For biodiversity-rich developing countries the most critical element in the CBD is sovereignty over bioresources by nation states, since the treaty recognizes their right to regulate and charge outsiders for access to their biodiversity. The sovereignty component is meant to replace the "common heritage" paradigm, which provides unrestricted access to biological resources. Ideally this paradigm shift is supposed to balance the way in which all involved interest groups can gain from biodiversity use by recognizing the economic, sociocultural, and environmental values of bioresources and the cost of their preservation.

In the time since the CBD was initiated, few of the 178 signatory nations have introduced legislation requiring benefit sharing for outside commercial access to their national bioresources, although some suggestions for implementation of the CBD have been brought forward (Iwu 1996; Buitron 1999). Despite the lukewarm response to the CBD by nation states, the global shift in awareness concerning tropical deforestation provided an opportunity for ethnobotanists to assert that everyone has an interest in preserving rainforests because they might contain compounds that could cure cancer, HIV-AIDS, and other diseases (Schultes et al. 1990; Elisabetsky et al. 1990); Cox et al. 1994; Schultes 1994; Brown 2003). In addition, income derived from the marketing of traditional medicinal knowledge was seen as an instrument to alleviate poverty and to finance conservation efforts (Reis 1993; Mooney 1993; Baker et al. 1995). Within a few years, however, for its critics, ethnobotany--initially seen as instrument that could help to salvage declining traditional knowledge and biodiversity- -had simply become an instrument of theft and "biopiracy."

In his book Who Owns Native Culture? anthropologist Michael Brown (2003) has a chapter entitled "The Ethnobotany Blues" which documents high-profile projects launched in Africa and Latin America in the early 1990s. They were organized under the U.S. initiative known as the International Cooperative Biodiversity Groups (ICBG), administered by the Fogarty International Center for Advanced Study in Health Sciences, part of the National Institutes of Health $(\mathrm{NIH})$, with additional funding from the National Science Foundation (NSF) and the U.S. Agency for International Development (USAID). Projects involved partnerships between American and hostcountry scientists as well as major drug companies, including Monsanto, Bristol-Myers Squibb, and American Cynamid. Brown (2003) describes ICBGPeru's troubled relationship between the Aguaruna of the Peruvian Amazon and Washington University (St. Louis), criticizing "paternalistic interventions that leave native peoples on the margins of decisionmaking and profit-taking" (p. 114). In Mexico, he documents how ICBG-Maya was shut down by an indigenous healers' organization and their activist allies on the grounds that it was an effort to steal native knowledge and resources. And he traces the failure of Shaman Pharmaceuticals, a California company which folded in 1999, in trying to adapt ethnobotanical bioprospecting to the "magicbullet" paradigm of the pharmaceutical industry.

In the late 1990s, anthropologist Cori Hayden (2003) conducted an ethnography of an ICBG bioprospecting agreement inaugurated in 1993 between the University of Arizona and its pharmaceutical partners (whose contribution was a discount on the use of their equipment!) and a team of plant researchers at Mexico's National Autonomous University (UNAM) headed by ethnobotanist Robert Bye. Under the agreement, UNAM researchers sent extracts of Mexican medicinal plants to the US in exchange for research funds and promises of a percentage of royalties 10 to 20 years in the future-should a drug result from the collaboration. The project was also designed to collect ethnobotanical knowledge and to direct some royalties back to source-communities. It 
concluded in 2003 when UNAM opted out of a second renewal.

Hayden elucidates the complex issues that emerged during the project, in particular the paradoxical effects of NIH's advocacy of benefitsharing according to the neo-liberal paradigm of bioprospecting. For $\mathrm{NIH}$, this meant that field researchers were supposed to sign contracts with each individual supplier of plants. Suppliers-and, by implication, their communities-were presumed to be "authors" and "stewards" of resources as well as future benefit-recipients. For UNAM ethnobotanists, drawing on a well-established research methodology, this meant collecting initial plant species from urban marketplaces and rural roadsides, a major disruption of a fundamental biopropecting assumption that plants and knowledge "come with" clearly identified local stewards, authors, and claimants.

In stark contrast with the ICBG approach, there is the Mexican Institute for Social Security (IMSS) model put into practice at its Southern Center for Biomedical Research (CIBIS) in Cuernavaca and focused on the production of herbal medicines. On 20 February 1997, Hayden (2003) interviewed Miguel Antinori, a prominent CIBIS official who denigrated bioprospecting agreements for using Mexico's chemists as "cheap labor" and for sending extracts abroad for "more sophisticated" work. Further, he added, "It's hard to see an assertion of [Mexican] national identity in these contextsup north, they just see Mexico as a source of raw material and certainly not as research partners or collaborators. Why don't they locate more of the development part here? Because they don't trust Mexican science."

Shaman Pharmaceuticals scientists Moran, King and Carlson (2001) discuss the irony in the situations described above, indicating that the majority of the biotech industry is not involved in bioprospecting, since most companies favor the use of cheaper and faster synthetic technologies over the complex process involved in exploring for natural products. Nonetheless, biotechnology spawns ethical, social, and legal debates at the margins of pharmaceutical bioprospecting, including the collaboration between big business and big science, the ethics of genetic engineering, and the patentability of life forms as well as ideas about genetics and racism, culture and ethnicity. However, it is significant to note that, since the inauguration of the CBD, no pharmaceutical bioprospecting product developed by using traditional knowledge has generated an economic profit. (But this does not mean that pharmaceutical companies do not try to impede or co-opt efforts to get natural plant products to market.) Also, only a small number of bioprospecting research expeditions begin by using ethnobotany as a discovery methodology, with the work soon evolving into economic botany as the laboratory focus shifts to the plant's chemistry, biological activity, and pharmacology/toxicology. During drug discovery, active chemical components are isolated, often modified, and patented. Patented information then becomes a commodity in itself.

Peruvian pharmaceutical researcher Angulo (2009) discusses new approaches to research on medicinal plants contrasting Western and Eastern methodologies. For example, whereas the West does not value popular wisdom and usage developed over centuries by local cultures, the East uses this knowledge as a paradigmatic base for its model of science. Whereas the West has exclusively followed the Cartesian model of scientific skepticism, Eastern pragmatism, building on tradition, has formalized usage and then applied the methods of modern science. Whereas the West has ignored traditional knowledge in designing artificial studies that isolate chemical components and evaluate their toxicity and bioactivity to later take finished products into clinical settings, the East has followed an inverse strategy, i.e., valuing traditional knowledge by applying original remedies and therapies in the medical clinic and then subjecting those that work to biochemical research and development. Whereas the West followed a basic research paradigm of random screening, component analysis and synthesis, the East recognized the holistic action of herbal medicines in seeking ways to industrialize them. As a result of the foregoing factors, Western science has developed economic botany, which uses a methodology of chemical taxonomy based on the assumption that only by knowing the chemistry of plants can we discover their active principles and 
bioactivity. This has led to the current emphasis on synthetic chemistry for the development of modern medicines.

Angulo (2009) points out that, by uncritically following the Western model for biochemical research promoted by large European and American pharmaceutical corporations, Peru has acquiesced to the notion that countries like Peru and Mexico lack the technical and economic resources necessary to compete with foreign consortiums. As a result, these countries, for the most part, have denigrated their own indigenous knowledge and neglected the development of viable national research programs in ethnobotany and ethnopharmacology. Joining Elisabetski et al. (1990), Angulo suggests that:

\begin{abstract}
"Traditional medicine should be the basis for the development of drugs, given that it includes the knowledge of the therapeutic value of local flora. Thus, knowledge of the practices of Traditional Medicine plays a crucial role in the selection of species to subsequently be considered as potential sources of universally applicable drugs. Elizabetsky concludes that the interaction between anthropology and ethnopharmacology is the basis on which should be developed the holistic investigation of medicinal plants in particular and healthcare in general."
\end{abstract}

We would only add that applied research on natural plant remedies should also be on the national agendas of Peru and neighboring republics.

By focusing on indigenous knowledge as it relates to the environment, the Convention on Biological Diversity managed to sidestep some of the more politically charged aspects of the intellectual property rights (IPR) issue. The greatest impact on concerns over indigenous and localcommunity rights can be traced to the mercurial rise of biotechnology on the international trade front and the 1995 version of the World Trade Organization (WTO) Agreement on Trade Related Aspects of Intellectual Property Rights (TRIPS). These two factors have created a large potential market for indigenous and local knowledge and resources, while at the same time raising concerns about the risk that these resources will be misappropriated. Thus this knowledge is receiving increasing international attention in terms of its relationship to human rights as well as its relevance to modern science. The situation has created opposing pressures calling for the rights of local and indigenous peoples on the one hand and further exploitation of their knowledge on the other. Moran, King and Carlson (2001), and Greaves (1995), indicate that the biggest problem with the orthodox intellectual property system is its focus on material aspects of knowledge at the expense of the cultural. They advocate recognition of alternative worldviews in the formulation of new indigenous knowledge rights that are localized, relevant, pertinent, and effective.

In their article in Cultural Survival Quarterly Bannister and Barrett (2001) contend that bioprospecting is a form of economic botany that can run contrary to the ethnobotanical objectives of protecting biological and cultural diversity. The economic focus of this activity highlights issues concerning indigenous rights, cultural knowledge, and traditional resources - areas in which current intellectual property protection regimes are inadequate and inappropriate. However, indigenous communities are increasingly forced to employ intellectual property rights to protect these resources. Protection issues ought to be addressed well before the point at which employing intellectual property mechanisms seems to be the only alternative. Significant control lies at the point of decision about publication and dissemination of knowledge to the wider community, which raises important questions about facilitating the appropriation of cultural knowledge. The authors advocate a more "precautionary" approach to ethnobotanical inquiry in assisting indigenous communities in protecting their cultural heritage and intellectual property rights.

Probably the major concern in many traditional communities is that their spiritual legacies will be profaned by a secularized and consumerdriven outside world. Often, however, legitimate economic considerations also play a role in the defensive reactions of these societies to the wellintended but naïve desire of the academic world to place its findings in the public domain. Greaves (1995) and Bannister and Barrett (2001) have warned that the downside in this approach is that a "colonializing archive" can become easily "mined" 
for clues in the search for new drugs without the inconvenience of fieldwork or inclusion of source communities in the benefits derived from products resulting from research.

However, although acknowledging genuine concerns about neocolonialism and biopiracy, we would submit that each situation has to be considered on its own merits, especially with regard to its specific cultural context. A first step in the evaluation process should involve the important distinction between "indigenous peoples" and "local communities" (King et al. 2001). The latter for the most part are farmers who speak the national language, practice the majority religion, and identify with the nation-state, especially with regard to their socioeconomic aspirations, whereas the former tend to be tribal and/or ethnic minorities, who seek collective rights and selfdetermination for their biological and cultural resources. Although it is often the case that in both communities traditional knowledge and resources are undocumented and in danger of disappearing, this danger tends to be more pressing in local communities as their members continue to adapt to privatization and globalization. In cases such as these successful ethnobotanical intervention requires a methodology that combines "salvage ethnography" with "rapid assessment". This is the methodology that we initially applied in Peru, motivated by our prior experience in Southern Ecuador where traditional knowledge of medicinal plants similar to those found in Northern Peru is diminishing at an alarming rate. However, with our database firmly established as a research vehicle, we can now turn our attention to facilitating proactive issues of education, conservation, and sustainable development of natural plant products.

India provides a positive example of the proactive application of this approach. Taking advantage of the "novelty" criterion in international patent law, with regard to the documentation of Ayurvedic and other traditional medicine, millennial Sanskrit texts as well as modern publications are included in a traditional knowledge database, which is subsequently provided to patent agencies. The expectation is that, by placing the knowledge about long-term cultural precedents for traditional uses in the public domain, this research will prove that contemporary patent applications derived from local medicinal knowledge lack originality, i.e., that they are not "novel" enough to qualify as inventions warranting protection under international patent law, and are thus not patentable.

Fortunately, in 2002, with the support of the International Phyto-Genetic Resource Institute (Rome, Italy), Peru promulgated Law 27811 for the protection of the collective knowledge of indigenous peoples related to biological resources. Article 17 of the law establishes a National Public Register to include collective knowledge that is in the public domain. This register is administered by INDECOPI (National Institute of Competitive Defense and Intellectual Property), with the obligation to send the information recorded to principal patent offices around the world, a protective defense mechanism intended to prevent the granting of patents which do not meet the criteria of novelty and degree of inventiveness (Venero 2005; Ferro et al. 2005).

As noted earlier, Peru has also activated the Peruvian National Commission Against Biopiracy. In the Congressional Forum of 2004 which led to the formation of the Commission a number of important issues were addressed, including intellectual property, the high protein cereal Quinua and biopiracy, passage of the law for the protection of Peruvian biodiversity and the collective knowledge of indigenous peoples, and efforts to annul the US patent for the virility stimulant Maca as well as suggestions for combating biopiracy(Ferro et al. 2005). Briefly noted was the issue of genetically modified foods, anticipated as a concern that was likely to emerge with approval of a free trade agreement with the]. When the Commission was legally mandated, later in 2004, 19 plant claims were slated for review. By 2010, claims for 69 plants were being researched, 17 cases of biopiracy had been identified, and seven (from France, Japan, and South Korea) had been successfully blocked. One hopes that in all these deliberations the following remarks by forum panelist Jorge Agurto (2005) will be borne in mind:

"The problem underlying biopiracy is the open recognition of the rights of the indigenous peoples and communities. Many times they have been excluded and marginalized from the politics of Government. Even today we encounter 
members of Congress who are either unaware of the existence of indigenous peoples or who do not recognize their rights. It is impossible to speak of biopiracy if we do not defend the holders of many genetic resources, those who have achieved the domestication, knowledge, and technology to utilize biodiversity in a sustainable fashion. They are also the holders of the right to prior informed consent, a fundamental right to know the objectives of the exploration and exploitation of their resources and traditional knowledge and the consequences or potential benefits that can come with industrial, commercial or scientific uses."

Spanish anthropologist Luisa Abad (2003) concludes in her book Ethnocide and Resistance in the Peruvian Amazon that foreign and domestic development policies contribute to the marginalization of indigenous peoples:

“Underdeveloped, developing, Third World, North-South..., perhaps the language has been changing in these times and the terminology has been adapting itself to partially new habits, but the unequal, hierarchical reality remains the same, given that those who exercise power continue to be the same. International assistance also keeps promoting unequal development between peoples."

\section{BIODIVERSITY CONSERVATION AND TRADITIONAL MEDICINE}

A policy report, Biodiversity, Traditional Knowledge and Community Health: Strengthening Linkages, published by the United Nations University--Institute of Advanced Studies in Yokohama, Japan addresses many of the issues discussed above (Unnikrishnan et al. 2012). Building on the WHO Alma Ata Declaration of 1978 relating to Traditional Medicine and primary health care, the UN Convention on Biological Diversity of 1992, and the UN's Middle Development Goals (MDGs) of 2011, this document shows that links between Traditional Medicine and biodiversity are strengthened by three processes: 1) a medical approach involving national efforts to integrate Traditional Medicine into institutional healthcare delivery which includes challenges related to safety, quality, efficacy, access, and regulation; 2) a market-oriented approach focused on drug development or tourism promotion focused on biomedical products and services as marketable commodities; and 3) a community-focused approach activated by civil society organizations focused on conservation implemented through a grassroots mobilization process involving health professionals, botanists, conservationists, and community activists.

The community-based approach shows allegiance to the Alma Ata primary health care model. Examples include the barefoot doctors strategy in China and the social health activist programs in India. Given the centrality of biodiversity in human lives, there still is a need to develop sustainable strategies for health maintenance combined with conservation of biological resources and linked to local knowledge and practices. This is relevant even in developed countries where there is an increasing demand for alternative and complementary medicine.

\section{TWO DECADES OF ETHNOBOTANICAL RESEARCH IN SOUTHERN ECUADOR AND NORTHERN PERU}

Work up to 2012 - besides developing a database of 510 medicinal plants (Bussmann et al. 2006 a,b: 2007a) and 974 remedies of mixtures (Bussmann et al. 2010a) has demonstrated that herbal commerce in Peru is a major economic resource (Bussmann et al. 2007b), which, although used alongside modern pharmaceutical products, is showing signs of diminished popular knowledge of applications (Bussmann et al. 2007 b,c, 2009 a). Laboratory research on most of the database has ranged from minimum inhibition concentrations (Bussmann et al. 2010b) to toxicity screening (Bussmann et al. 2011) as well as bioassays to determine antibacterial activity (Bussmann et al. 2008 a,b,c; 2009 b) and phytochemical analysis (Bussmann et al. 2009c; Perez et al. 2012) with more focused analyses of herbal treatments for acne (Bussmann et al. 2008a) and malaria (Bussmann et al. 2010c). Other studies have sought to identify Ulluchu, a ceremonial plant of the pre-Hispanic Moche culture (Bussmann et al. 2009d) as well as surveying colonial sources of medicinal plants in 
Northern Peru and Southern Ecuador (Bussmann et al. 2006b). An ethnography of peasant herbalists which documented aspects of the market supply chain showed that suppliers are not adequately remunerated and revealed threats posed by lack of conservation measures and overharvesting (Revene et al. 2008; Carillo 2012) criticized the scientific reductionism of laboratory research in attempting to appropriately verify traditional remedies. Anthropological studies of traditional curanderos and their curing altars (mesas) include articles by Sharon et al. (2009), Sharon \& Gálvez (2009), Sharon (2009); and Glass-Coffin et al. (2004).

It is worth noting that, during the decade that we have been working in the field and the laboratory, there has been a sea change in attitudes and perceptions of Traditional Medicine. In Trujillo, Lima and Arequipa a pilot program prescribing medicinal plants, scientifically validated by $\mathrm{WHO} /$ PAHO, has been initiated by EsSalud's National Program for Complementary Medicine, an initiative begun in 1999 with three centers which has grown to 26 to date (Fernandez 2009). In Trujillo, the Missouri Botanical Garden's Sacred Seeds program has started an herbal garden and educational outreach program at the site museum of the pre-Hispanic Chimú city of Chan Chan. In Huamachuco, a program of ethnobotany and conservation manifest in community gardens and seed banks of medicinal and food plants is slowly emerging through collaboration between three local peasant communities, the Beneficencia Publica and regional hospital, MBG's Sacred Seeds program, MHIRT, and the Peace Corps. Future work will involve developing a supply chain between Huamachuco and CCM-Trujillo with scientific validation by MBG, UB(SUNY), the Biotransformation \& Natural Products Laboratory at UNT, and the Interdisciplinary Research Group at UPAO as coordinated by MHIRT and MBG.

\section{Plant nomenclature in Northern Peru}

The naming of plant species follows three general patterns. Plant names already used by original indigenous populations are often maintained, although slightly modified. Plants similar to species already known, or with similar habitus, often receive the same name (transposition). In other cases, completely new names are created (neology) (Van den Eynden et al.2004).

The vernacular names of the plants used in Northern Peru reflect the historical development of plant use in the region. Introduced species (e.g. Apium graveolens - Apio, Foeniculum vulgare Hinojo), native species similar to species found in Spain (e.g. Adiantum concinnum - Culantrillo, Matricaria frigidum - Manzanilla), as well as species growing mostly in the coastal regions of the area (e.g. Alternanthera porrigens - Sanguinaria), are often addressed with names derived from Spanish roots. Plants from the mountain forests and especially the Andean highlands or the Amazon are often known by their Quechua names (e.g. Pellaea ternifolia - Cuti Cuti, Amaranthus caudatus - Quihuicha, Banisteriopsis caapi - Ayahuasca), and a few plant names can be traced back to Mochica (the original indigenous language spoken at the coast of Northern Peru) roots (e.g. Nectandra spp. Espingo) (Bussmann et al. 2009e). Van den Eynden et al. (2004) observed similar patterns in Southern Ecuador, although her study focused only on edible species. Nine hundred thirty-eight vernacular names were recorded for 510 plant species. About one third if all names represented Quechua names or had Mochica roots, while $66.5 \%$ of all names were of Spanish origin or at least had Spanish components. In comparison, $41 \%$ of the vernacular names of edible plants in Southern Ecuador were found to be of Spanish origin. More than half of the indigenous species carried only one vernacular name, with the remaining species carrying a variety of indigenous names, often derived from the same root. In comparison, almost $75 \%$ of the introductions were known by one name only. The slight differences in plant names indicate that the species have been used in the region for a long time, and that their names reflect small variations in the local dialects.

\section{Two decades of Ethnobotany in Northern Peru and Southern Ecuador}

Since 1995 ethnobotanical data were collected in Northern Peru and Southern Ecuador (Fig. 1), 
from plant sellers while purchasing plant materials in local markets, by accompanying local healers (curanderos) to the markets when they purchased plants for curing sessions, and into the field when they were harvesting. In addition, plants were collected by the project members in the field, and--together with the material purchased in the markets--taken to the homes of curanderos to discuss the plants' healing properties, applications, harvesting methodology, and origins. The project region represents a floristic hotspot in Peru, with striking gradients from coastal deserts and dry foreats, to some of the wettest Paramos known, to the Amazon lowlands (Fig. 2). At the curanderos' homes the authors also observed the preparation of remedies and participated in healing rituals. Plant uses were discussed in detail with informants, after seeking prior informed consent from each respondent. Following a semi-structured interview technique, respondents were asked to provide detailed information about the vernacular plant name in Spanish or Quechua; plant properties (hot/cold); harvesting region; ailments for which a plant was used; best harvesting time and season; plant parts used as well as mode of preparation and application; and specific instructions for the preparation of remedies, including the addition of other plant species. All interviews were carried out in Spanish, with at least one of the authors present. Both authors are fluent in Spanish, and no interpreter was needed to conduct the interviews. Data on plant species, families, vernacular names, plant parts used, traditional uses, and modalities of use were recorded.

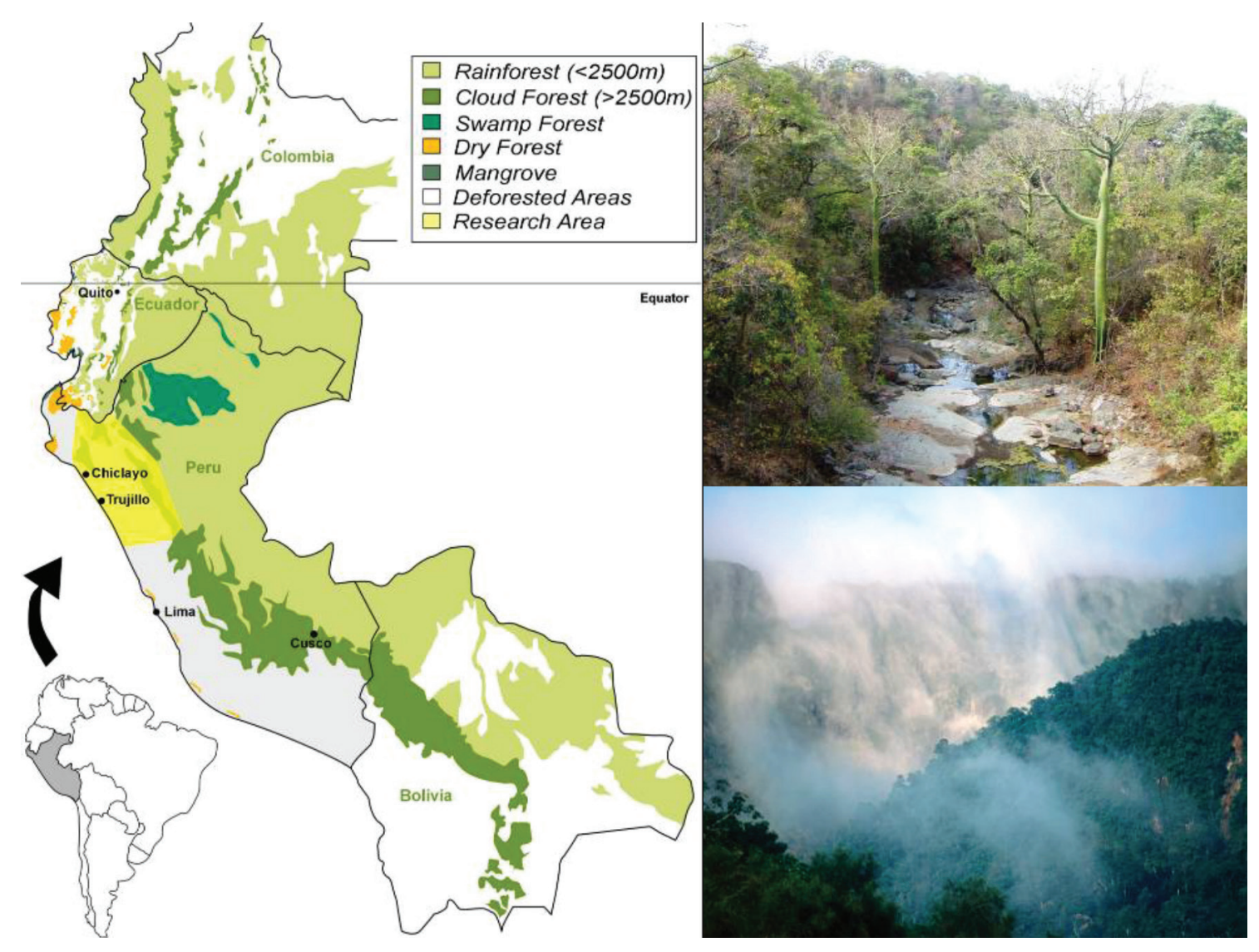

Figure 1. Study area: Peruvian Departments of Amazonas, Piura, Lambayeque, La Libertad, Cajamarca, San Martin, and the Ecuadorian Province of Loja. Dry forest (above) and Cloudforest (below) indicating the striking moisture gradient. 


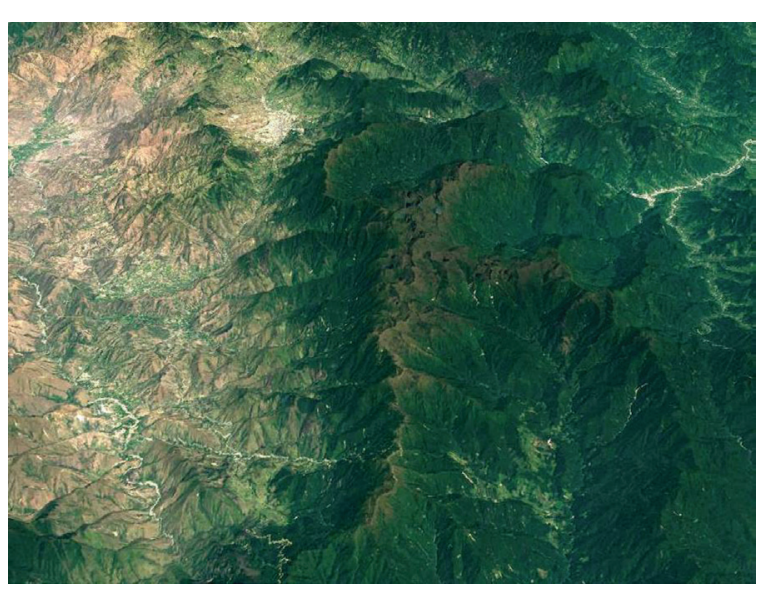

Figure 2. A $50 \mathrm{~km}$ transect in Southern Ecuador from dry forest $(250 \mathrm{~mm}$ precipitation, left) to Podocarpus National Park Paramo $(10000 \mathrm{~mm}$ precipitation, middle) to Amazon lowlands (right).

Many of the species reported from northern Peru are widely known by curanderos and herb vendors as well as the general population of the region, and are employed for a large number of medical conditions. One hundred fifty to two hundred plant species, including most of the introductions, are commonly sold in the local markets (Bussmann et al. 2006b). Rare indigenous species were either collected by the healers themselves, or are ordered from special collectors or herb vendors. The same plants were frequently used by a variety of healers for the same purposes, with only slight variations in recipes. However, different healers might give preference to different species for the treatment of the same medical condition. All species found were well known to the healers and herb vendors involved in the study, even if they themselves did not use or sell the species in question. Many species were often easily recognized by their vernacular names by other members of the population. This indicates that these remedies have been in use for a long time by many people. The use of some species, most prominently San Pedro (Echinopsis pachanoi), Maichil (Thevetia peruviana) and Ishpingo (various species of Nectandra), can be traced back to the Moche culture (AD 100-800). Representations of these plants are frequently found on Moche ceramics, and the remains of some were found in a variety of burials of high-ranking individuals of the Moche elite, e.g., the tomb of the Lord of Sipán (Bussmann et al. 2009e).

\section{Medicinal Uses}

Five hundred-ten plants with medicinal properties were registered in Northern Peru. The same species was often used for various medical conditions and applied in different ways for the same condition. For example, nervous disorders might be treated using different parts of a plant in different applications, e.g., topical (as a Poultice or Bath), oral (ingestion of plant extracts), and by supplying the patient with a seguro, a bottle filled with herbs and perfumes, which serves as a protective charm. Two thousand four hundred ninety-nine different uses were registered for the 510 species encountered. In the following, the total number of uses/applications and the number of species used are given, rather than only the number of plant species used to treat a condition, in order to emphasize the importance of the treatment of specific conditions.

The highest number of species $(207,40.4 \%)$ is used for the treatment of "magical" ailments, with $682(27.3 \%)$ of all conditions. Respiratory problems (95 species, 18.5\%) were mentioned as 233 (9.3\%) of all uses; 98 species (19.1\%) are used to treat psychosomatic and nervous system problems, with 176 applications (7\%). Kidney and Urinary tract disorders are treated with 85 species $(16.6 \%)$, for 111 conditions (4.4\%). Rheumatic and arthritic symptoms are mentioned in 103 uses $(4.1 \%)$, with 45 species $(8.8 \%)$ used for treatment. Infections of female organs are treated with 66 species $(12.9 \%)$, and comprised $100(4.4 \%)$ of all conditions.

Treatments are most often performed in the homes of the individual healers, who normally have their mesas (healing altars) set up in their backyards (Fig. 3). Healers also treat patients at altars and consultation chambers (consultorios) in their homes, at sacred sites in the countryside, or at sacred lagoons high in the mountains. Healing altars (mesas) bearing a large number of power objects are often employed (Fig. 4). A curing ceremony normally involves purification of the patient by orally spraying blessed and enchanted herbal extracts on the whole body to fend off evil 
spirits and by nasal ingestion of tobacco juice and perfumes. Plant supplies come mostly from the local markets (Fig. 5).

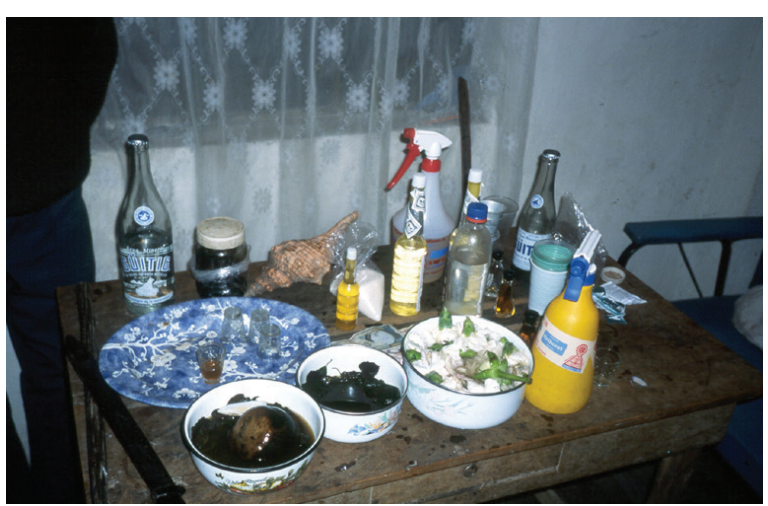

Figure 3. Contremporary healing altar (mesa) in Southern Ecuador

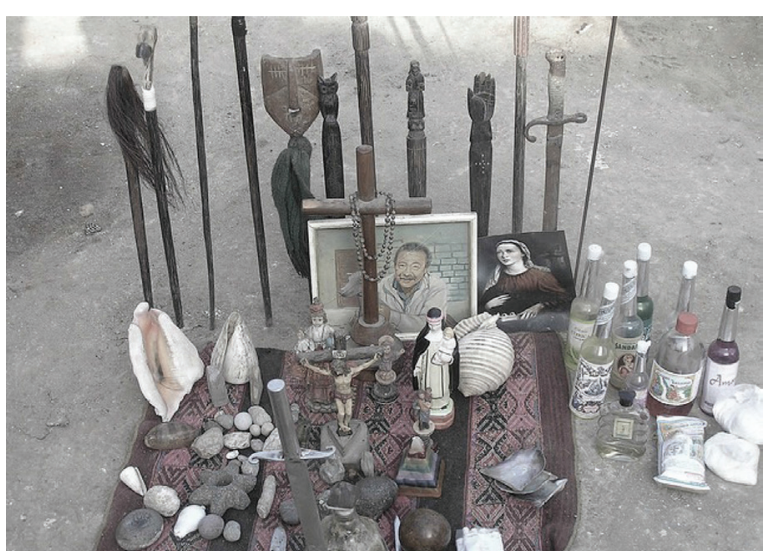

Figure 4. Contemporary healing altar (mesa) in Northern Peru

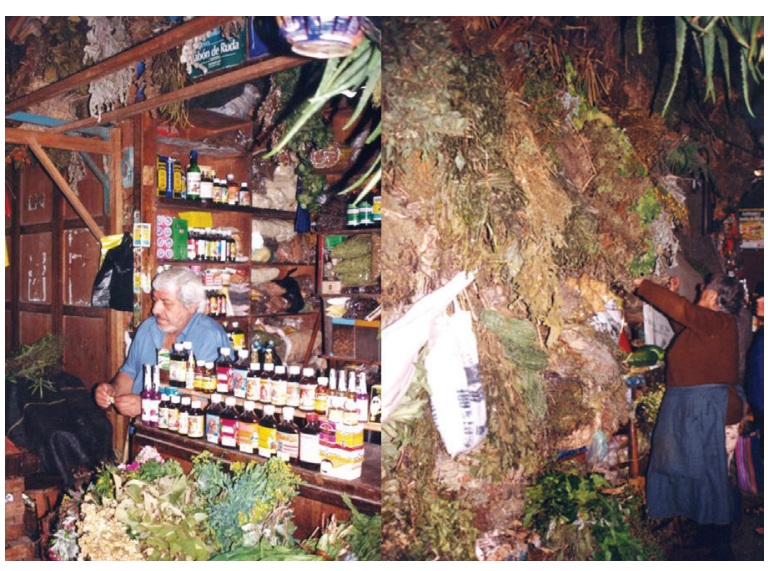

Figure 5. Plant preparations and raw plants for sale in Mercado Mayorista, Trujillo.
Two hundred seventy-eight different medical conditions were recorded. Most plants were used for the treatment of multiple ailments. The large variety of conditions is grouped into 72 main categories.

\section{Magical Uses}

Mental, neurological and psychosomatic disorders are highly prevalent on a global scale. The burden of mental health problems has been seriously underestimated. Although neurological problems are only responsible for about $1 \%$ of global deaths, they contribute to over $11 \%$ of the global disease burden. It is estimated that this share will rise to $15 \%$ by 2020 (WHO 2009). Western medicine often offers little help for patients afflicted by these disorders.

Healing altars (mesas) in Northern Peru often follow the old tradition by including a large variety of "power objects," frequently with a "pagan" background. Objects such as seashells, preColumbian ceramics, staffs, stones, etc. are very common on Peruvian mesas and are blended with Christian symbols such as crosses and images of saints. Treatments are most often performed in the homes of the individual healers, who normally have their mesas set up in their backyards. Healers also treat patients at altars and consultation chambers (consultorios) in their homes, at sacred sites in the countryside, or at sacred lagoons high up in the mountains. A curing ceremony normally involves purification of the patient by orally spraying blessed and enchanted herbal extracts on the whole body to fend off evil spirits and by "Spiritual Flowerings" (baños de florecimiento). In most cases, the cleansing of the patients involves drinking boiled San Pedro juice and the nasal ingestion of tobacco juice and perfumes. Sometimes extracts of Jimson weed (Datura ferox), Brugmansia spp., and tobacco are also used to purify the patients. While the incantations used by healers during their curing sessions include Christian components (e.g., the invocation of Christ, the Virgin Mary, and any number of saints), references to Andean cosmology (e.g., to the apus or the spirits of the mountains) are very common. The use of guinea pigs as diagnostic instruments 
is standard in Northern Peru (Sharon 1978, 1980, 1994, 2000; Joralemon et al. 1993).

Traditional Medicine is also gaining more attention by national governments and health providers. Peru's National Program in Complementary Medicine and the Pan American Health Organization recently compared Complementary Medicine to allopathic medicine in clinics and hospitals operating within the Peruvian Social Security System (EsSalud 2000).

Mal Aire (Bad Air), Mal Viento (Bad Wnd), Susto or Espanto (Fright), Mal Ojo (Evil Eye) and Daño or Brujería(Sorcery) are seen as very commonillnesses in Andean society. Causes include sudden changes in body temperature (Mal Aire, Mal Viento), any kind of shock (Susto, Espanto), "humors" or spells cast by other people (Mal Ojo), poisoned food, curses, etc. (Daño, Brujeria). Medical problems caused by outside influences were reported in a wide variety of studies (Girault 1987; Oblitas 1992). The Western concept of "psychosomatic disorders" comes closest to characterizing these illnesses.

These illness categories are deeply rooted in Andean society, and Western medicine does not offer efficient alternatives to traditional treatment. This might explain why this category has still such outstanding importance. Treatment in many cases involved the participation of the patient in a cleansing ceremony or limpia. This could either be a relatively simple spraying with perfumes and holy water, or an allnight ceremony involving the healer's curing altar (mesa). In the days after an allnight ceremony, patients are normally treated with a baño de florecimiento (flowering bath) in order to relieve them of any remaining adversary symptoms or spirits. In addition, patients frequently receive seguros (herbal amulets) for protection against further evil influences and for good luck. Seguros are flasks filled with powerful herbs, as well as perfumes, pictures of saints, and the hair and fingernails of the patient.

The enormous number of plant species used for the treatment of psychosomatic disorders indicates that the curanderos of Northern Peru are valued specialists who are consulted mainly for these conditions. This is all the more interesting since Western medicine has still not found efficient treatments for psychosomatic disorders. The plant species used for "magical or ritual" disorders come mostly from the high Andes, especially from the vicinity of sacred lakes, since plants from those regions are regarded as especially powerful. This links the present day curing practices directly to ancient Andean cosmology. The use of purgatives and laxatives, to literally "expel" evil spirits is also very common.

A total of 222 plant species belonging to 172 genera and 78 families were documented and identified as herbal remedies used to treat nervous system problems in Northern Peru. Most species used were Asteraceae (36 species, 16.21\%), followed by Solanaceae ( 15 species, $6.76 \%$ ) and Lamiaceae (14 species, 6.31\%). The most important nervous system families are somewhat over-represented in comparison to the overall medicinal flora, while some other medicinally important families (e.g. Poaceae, Cucurbitaceae, Euphorbiaceae) are completely missing or under-represented from the nervous disorder portfolio (Bussmann et al. 2006b).

The majority of herbal preparations were prepared from the whole plant $(31.56 \%)$, while the leaves $(24.48 \%)$, stems $(21.24 \%)$, and flowers $(8.55 \%)$ were used less frequently. Whole plants and stems were more often used than characteristic for the overall medicinal preparations found in the region (Bussmann et al. 2006b). This indicates that the local healers count on a very well developed knowledge about the properties of different plant parts. In over $60 \%$ of the cases fresh plant material was used to prepare remedies, which differs slightly from the average herbal preparation mode in Northern Peru. Interestingly, only about 36\% of the remedies were applied orally, while the majority was applied topically $(46.65 \%)$, often as bath, and the remaining ones were used as spiritual safeguard (seguro). This is different from the regional average of application, and underlines the importance of spiritually oriented treatments. Over $79 \%$ of all remedies were prepared as mixtures with multiple ingredients by boiling plant material either in water or in sugarcane spirit.

\section{Respiratory System}

The WHO reports that respiratory illnesses are of high importance as a cause of death and 
morbidity at a global scale. WHO elaborated a Strategy for Prevention and Control of Chronic Respiratory Diseases (CRDs), (WHO 2002), and respiratory problems are a major cause for infant deaths in Peru (Weil 1978).

A total of 91 plant species belonging to 82 genera and 48 families were documented and identified as respiratory system herbal remedies in Northern Peru. Most species used were Asteraceae (15 species, 16.67\%), followed by Lamiaceae and Fabaceae $(8.89 \%$ and $5.56 \% \%)$. Most other families contributed only one species each to the pharmacopoeia. The most important families are clearly similarly well represented in comparison to the overall medicinal flora, although some other medicinally important families (e.g. Euphorbiaceae, Lycopodiaceae, Cucurbitaceae) are completely missing from the respiratory portfolio (Bussmann et al. 2006a).

The majority of respiratory disorder herbal preparations were prepared from the leaves of plants $(27.69 \%)$, while the whole plant $(18.46 \%)$, flowers $(13.85 \%)$ and stems (17.69\%) were used less frequently [125]. This indicates that the local healers count on a very well developed knowledge about the properties of different plant parts. In almost $55 \%$ of the cases fresh plant material was used to prepare remedies, which differs little from the average herbal preparation mode in Northern Peru. About $86 \%$ of the remedies were applied orally, while the remaining ones were applied topically. Over half of all remedies were prepared as mixtures of multiple ingredients by boiling plant material either in water or in sugarcane spirit.

Respiratory disorders are so common globally, and over-the counter remedies, both allopathic and complementary, so frequently sold, that much effort has been put into the verification of traditional remedies. Almost $50 \%$ of the plants found in the respiratory pharmacopoeia of Northern Peru, or their congeners have been studied for their medicinal properties. The original hypothesis that many species employed for respiratory illnesses would be non-native, introduced to treat diseases that were originally also introduced by colonialists, did not hold however. Quite contrarily, many remedies for respiratory ailments are native to the study area. From this perspective it is surprising to see how many species have actually been studied at least preliminarily.

\section{Urinary System (Kidneys, Bladder)}

The recent WHO report on urinary tract infections (UTI) indicates that UTIs are one of the most common bacterial infections seen, in particular in children. It has been estimated that UTI are diagnosed in $1 \%$ of boys and $3-8 \%$ of girls. In the first year of life UTI is more prevalent in boys with rates of $2.7 \%$ compared with $0.7 \%$ in girls. The reported rate of recurrent UTI is around $12-30 \%$ with risk greater in infants $<6$ months, severe vesico-ureteric reflux and abnormal nuclear renal scans at time of first infection (WHO 2005). Studies have shown a higher UTI prevalence of $8-35 \%$ in malnourished children, with the risk of bacteriuria increasing significantly with the severity of malnutrition (WHO 2005).

A total of 69 plant species belonging to 61 genera and 43 families were documented and identified as herbal remedies for kidney- and urinary tract problems in Northern Peru. Most species used were Asteraceae (8species, 11.43\%), followed by Fabaceae and Poaceae (both 5 species, $7.14 \%)$. All other families mostly contributed only one species each to the pharmacopoeia. The most important families are represented similarly as in the overall medicinal flora, while some other medicinally important families (e.g. Lycopodiaceae, Cucurbitaceae) are completely missing from the kidney portfolio (Bussmann et al. 2006b)..

The majority of kidney herbal preparations were prepared from the whole plant $(27.78 \%)$, while the leaves of plants (25.56\%), flowers (12.22\%) and stems (16.67\%) were used less frequently (Bussmann et al. 2006b). This indicates that the local healers count on a very well developed knowledge about the properties of different plant parts. In almost $64 \%$ of the cases fresh plant material was used to prepare remedies, which differs little from the average herbal preparation mode in Northern Peru. About $88 \%$ of the remedies were applied orally, while the remaining ones were applied topically. Over half of all remedies were prepared as mixtures of multiple ingredients by boiling plant material either in water or in sugarcane spirit. 
Kidney and urinary system problems are very common globally, but allopathic treatments, in particular with regard to renal calculi, are mostly focused on dilation of the ureter, and pain management. Although a large number of plants are used in traditional medicine to treat this problem, less than $35 \%$ of the plants found in Peru or their congeners have been studied at all for their medicinal properties. Kidney and urinary tract diseases are a major health challenge worldwide. Many plant species are traditionally used for kidney disease treatment, and some have been investigated for their efficacy with positive results. An often-limiting factor to these investigations is lack of comprehensive ethnobotanical data to help choose plant candidates for potency/efficacy tests. Since the plant parts utilized in preparation of kidney remedies are reported in this survey, it serves as an indication of species that may need further ecological assessment on their regeneration status.

\section{Rheumatic Problems}

The National Institutes of Health (NIH) reports that an estimated 23.5 million Americans suffer from autoimmune diseases and that this number is expected to grow. Medical research has currently identified 80-100 autoimmune diseases, and 40 additional diseases are suspected to have an autoimmune basis. Autoimmune diseases collectively rank in the top ten leading causes of death for women aged from adolescents up to age 64. In Western medicine, the most common treatments are immuno-suppressants, which are known to have devastating long-term side effects (Gillett et al. 2000).

The housing conditions already described, as well as difficult working conditions, lead to a wide spectrum of muscular-skeletal disorders, including rheumatism, arthritis, and bone- and muscle-pain. A total of 55 plant species belonging to 53 genera and 43 families were documented and identified as autoimmune herbal remedies in Northern Peru. Most species used were Fabaceae (4 species, $7.27 \%)$, followed by Rosaceae and Myrtaceae (both 3 species, $5.45 \%)$. All other families contributed only one or two species each to the. The most important families are clearly over-represented in comparison to the overall medicinal flora, while some other medicinally important families (e.g. Asteraceae, Lamiaceae, Euphorbiaceae, Apiaceae, Lycopodiaceae, Cucurbitaceae) are less commonly used for the treatment of autoimmune disorders and pain or are completely missing from the portfolio (Bussmann et al. 2006b).

The majority of the herbal preparations were prepared from the leaves of plants $(35 \%)$, while the whole plant $(21.25 \%)$, and stems $(17.5 \%)$ were used less frequently [126]. This indicates that the local healers count on a very well developed knowledge about the properties of different plant parts. In $60 \%$ of the cases fresh plant material was used to prepare remedies, which differs little from the average herbal preparation mode in Northern Peru. Only about $55 \%$ of the remedies were applied orally, while the remaining ones were applied topically. This is little different from the regional average of application. Over half of all remedies were prepared as mixtures of multiple ingredients by boiling plant material either in water or in sugarcane spirit.

Very little western scientific evidence exists to prove the efficacy of the species employed as remedies in Northern Peru to treat autoimmune problems. Less than a pitiful $22 \%$ of the plants found or their congeners have been studied at all for their medicinal properties.

\section{Internal Organs (Liver, Gallbladder)}

Disorders of internal organs fall far behind the most commonly treated medical conditions. (Bussmann et al. 2006b). This is an indication that curanderos in Northern Peru are to a large extent specializing in the treatment of psychosomatic disorders, and that "bodily" illnesses are treated more as a sideline. However, a large number of plant species was used by local healers to treat liver and gallbladder ailments.

A total of 51 plant species belonging to 43 genera and 31 families were documented and identified as liver and gallbladder herbal remedies in Northern Peru. Most species used were Asteraceae (9 species, $17.66 \%$ ), followed by Euphorbiaceae (4 species, 7.85\%) and Gentianaceae (3 species, $5.89 \%)$. All other families contributed only one or 
two species each to the pharmacopoeia. Asteraceae are clearly over-represented in comparison to the overall medicinal flora, while some other medicinally important families (e.g. Solanaceae, Lycopodiaceae, Cucurbitaceae, Rosaceae) are completely missing from the liver ailment portfolio (Bussmann et al. 2006b).

The majority of herbal preparations employed for liver ailments were prepared from the whole plants $(35.38 \%)$, while the leaves $(24.61 \%)$, flowers $(9.23 \%)$ and stems $(12.32 \%)$ were used less frequently. Whole plants were more often used than characteristic for the overall medicinal preparations found in the region, while stems of plants were employed much less frequently (Bussmann et al. 2006b). This indicates that the local healers have a less well-developed knowledge about the constituents of individual plant parts in the case of liver and gallbladder treatments than for other applications. In almost $65 \%$ of the cases fresh plant material was used to prepare remedies, which differs little from the average herbal preparation mode in Northern Peru. Most of the remedies were applied orally (over 90\%), while the remaining ones were applied topically. This is highly different from the regional average of application. Over $71 \%$ of all remedies were prepared as mixtures with multiple ingredients by boiling plant material either in water or in sugarcane spirit. This indicates that the local healers have a very profound knowledge about the synergistic effects of plants in multi-ingredient preparations.

Almost no scientific evidence exists to date to prove the efficacy of the species employed as liver and gallbladder remedies in Northern Peru. Only $8 \%$ of the plants found or related species in the same genus have been studied at all.

\section{Diarrhea, stomach problems and other intestinal ailments}

Foodborne diseases are a serious public health problem worldwide. Some foodborne diseases are well recognized, but have recently become more common. Outbreaks of salmonellosis have been reported for decades, but within the past 25 years the disease has increased in incidence on many continents. While cholera has devastated much of Asia and Africa for years, its introduction for the first time in almost a century on the South American continent in 1991 makes it another example of an infectious disease that is both wellrecognized and emerging. While cholera is often waterborne, many foods also transmit infection. Infection with Escherichia coli serotype 0157:H7 ( $E$. coli) was first described in 1982. Subsequently, it has emerged rapidly as a major cause of bloody diarrhea and acute renal failure. Outbreaks of infection, generally associated with beef, have been reported in Australia, Canada, Japan, United States, in various European countries, and in southern Africa (WHO 2002).

A total of 75 plant species belonging to 62 genera and 39 families were documented and identified as herbal remedies for intestinal ailments in Northern Peru. Most species used were Lamiaceae (13.33\%), followed by Asteraceae and Rutaceae (both 5 species, 6.67\%). Most other families contributed only one species each to the pharmacopoeia. The most important anti-infectious families are clearly over-represented in comparison to the overall medicinal flora, while some other medicinally important families (e.g. Asteraceae), are much less important (Bussmann et al. 2006b).

The majority of anti-infectious herbal preparations were prepared from the leaves of plants $(29.25 \%)$, the whole plant $(22.64 \%)$, and stems (16.04\%). This indicates that the local healers count on a very well developed knowledge about the properties of different plant parts. In almost $60 \%$ of the cases fresh plant material was used to prepare remedies, which differs little from the average herbal preparation mode in Northern Peru. Interestingly, only about $83 \%$ of the remedies were applied orally, while the remaining ones were applied topically. Over half of all remedies were prepared as mixtures of multiple ingredients by boiling plant material either in water or in sugarcane spirit.

Large parts of the species used for intestinal disorders in Northern Peru are introductions from other parts of the world, especially Europe. Many of these are well known, and almost $50 \%$ of the plants found in this study have shown efficacy in scientific studies. 


\section{Reproductive problems and female health}

According to 1999 WHO estimates reproductive problems, including, 340 million new cases of curable Sexually Transmitted Diseases (STIs; syphilis, gonorrhoea, chlamydia and trichomoniasis) occur annually throughout the world in adults aged 15-49 years. In developing countries, STIs and their complications rank in the top five disease categories for which adults seek health care. Infection with STIs can lead to acute symptoms, chronic infection and serious delayed consequences such as infertility, ectopic pregnancy, cervical cancer and the untimely death of infants and adults (WHO 2007).

A total of 105 plant species belonging to 91 genera and 62 families were documented and identified as herbal remedies for reproductive problems in Northern Peru. Most species used were Asteraceae $(9.52 \%)$, followed by Lamiaceae and Fabaceae $(8.57 \%$ and $6.67 \%)$. Other families were less important, and 44 contributed only one species each to the pharmacopoeia. The most important families are clearly represented very similarly to their overall importance in the local pharmacopoeia (Bussmann et al. 2006b)..

The majority of herbal preparations for reproductive issues were prepared from the leaves of plants $(22.72 \%)$, the whole plant $(21.97 \%)$, and stems $(21.21 \%)$, while other plant parts were used much less frequently. This indicates that the local healers count on a very well developed knowledge about the properties of different plant parts. In almost $62 \%$ of the cases fresh plant material was used to prepare remedies, which differs little from the average herbal preparation mode in Northern Peru. Over $70 \%$ of the remedies were applied orally, while the remaining ones were applied topically. Many remedies were prepared as mixtures of multiple ingredients by boiling plant material either in water or in sugarcane spirit.

Little scientific evidence exists to prove the efficacy of the species employed as reproductive disorder remedies in Northern Peru. Only 34\% of the plants found or their congeners have been studied at all for their medicinal properties.

\section{Heart and Circulatory System}

Cardiovascular diseases are collectively the number one cause of death on the globe, accounting for over $30 \%$ of all deaths worldwide, $80 \%$ of which occur in lower income countries with often little western healthcare available. Lower income groups have generally a higher prevalence of risk factors (WHO 2009). Traditional Medicine is used globally and has rapidly growing economic importance. In developing countries,

Traditional healers are frequently consulted to treat heart problems and disorders of the circulatory system. The healers encountered used a wide variety of terms relating to heart problems, that in part generalized the condition (e.g. "heart disease"), included references to conditions as underlying cause of heart problems (e.g. "cholesterol"), or simply used terms to indicated treatment options (e.g. "blood irrigation" as term referring to "thin" a patients blood, "blood purification," or "refreshing the heart" as terms indicating a process cleansing the blood from suspected toxins, or "blood circulation," indicating a treatment that would improve circulation). The use of western style biomedicinal terms is not surprising, given that all informants were of Mestizo origin, and lived in an urban environment.

Most treatments of the circulatory system involved the purification of the blood in order to improve the general condition of the patient. In addition, the fashionable concept of "weight management" and conditions related to obesity has entered into the domain of Peruvian healers. All healers readily acknowledge the negative influence of high cholesterol levels, and plant remedies were used specifically to lower cholesterol as well as weight loss therapies, while plants used for weight gain were insignificant.

A total of 60 plant species belonging to 52 genera and 33 families were documented and identified as heart herbal remedies in Northern Peru. Most species used were Asteraceae (7 species, $11.67 \%)$, followed by Lamiaceae $(6$ species, $10 \%$ ), and Solanaceae (4 species, $6.67 \%$ ). Fabaceae, Amaranthaceae and Cucurbitaceae each contributed 3 species $(5 \%)$ to the heart pharmacopoeia. All other twenty-seven families 
contributed only one or two species each to the pharmacopoeia. Asteraceae are in general underrepresented as heart remedies in comparison to the medicinal flora used in Northern Peru; Lamiaceae and Euphorbiaceae are clearly over-represented in comparison to the overall medicinal flora, while some other medicinally important families (e.g. Poaceae, Lycopodiaceae, Rosaceae) are completely missing from the heart portfolio (Bussmann et al. 2006b)..

The majority of heart remedies were prepared from whole plants $(37.18 \%)$, while the leaves $(24.36 \%)$, stems $(15.38 \%)$, and flowers $(7.69 \%)$ were used less frequently. Whole plants were more often used than characteristic for the overall medicinal preparations found in the region (Bussmann et al. 2006b).. In almost $70 \%$ of the cases fresh plant material was used to prepare remedies, which differs little from the main herbal preparation mode in Northern Peru. Over $90 \%$ of the remedies were applied orally, while the remaining ones were applied topically. This is very different from the regional average of application. Over $65 \%$ of all remedies were prepared as mixtures with multiple ingredients by boiling plant material either in water or in sugarcane spirit. This indicates that the local healers have a very profound knowledge about the synergistic effects of plants in multi-ingredient preparations.

Little scientific evidence exists to date to prove the efficacy of the species employed as heart remedies in Northern Peru. Only $33 \%$ of the plants found or related species in the same genus have been studied at all.

\section{Inflammation and Bacterial Infections}

Bacterial infections and inflammation are among the ailments responsible for a large number of deaths worldwide, and are often treated by traditional healers (Bussmann et al. 2006a; WHO 2009).

A total of 96 plant species belonging to 84 genera and 46 families were documented and identified as anti-infective herbal remedies in Northern Peru. Twenty percent of the species were introductions, while $80 \%$ belonged to the native flora of Peru. Most species used belong to Asteraceae (18.95\%), followed by Fabaceae and Euphorbiaceae $(7.37 \%$ and $5.26 \%$ ). Most other families contributed only one species each to the pharmacopoeia. The most important anti-infectious families were overrepresented in comparison to the overall medicinal flora, while some other medicinally important families (e.g. Lycopodiaceae, Cucurbitaceae) are completely missing from the anti-infective portfolio.

The majority of herbal preparations were prepared from the leaves of plants $(31.34 \%)$, while the whole plant $(18.66 \%)$, flowers $(12.69 \%)$ and stems $(17.16 \%)$ were used less frequently. In almost $67 \%$ of the cases fresh plant material was used to prepare remedies. Only about $55 \%$ of the remedies were applied orally, while the remaining ones were applied topically. Over half of all remedies were prepared as mixtures of multiple ingredients by boiling plant material either in water or in sugarcane spirit. Infections, in particular by strains of Staphylococcus aureus are very common, and increasingly difficult to treat, due to widespread formation of drug resistance. Fungal infections, due to the structure of the organisms involved, have always been a hard task to treat. Given the high importance of infections, it is not surprising that anti-infective agents are high on the list for drug development, and a large number of species used traditionally, have undergone screening. Almost $43 \%$ of the plants used in Northern Peru to treat infections, or their congeners have been studied for their medicinal properties.

\section{Malaria and Fever}

Malaria is still a major global public health problem in most tropical countries. It is thought that malaria is by far the most serious tropical disease causing one to two million deaths per year, and it plays a major role in the high mortality seen in infants and children (El Kamali et al. 1997; Milliken 1997). It is also responsible for miscarriages, premature deliveries, growth retardation, low birth weight and anemia (Connally 1996; Gbile 1984; Minakawa et al. 2002; Hay et al. 2003).

The World Health Organization (WHO) has estimated that about 2 billion people in over 100 countries are exposed to malaria, with 247 
million cases in 2006 alone, and half of the world's population is potentially exposed to the disease (WHO 2009). The worsening global economic situation makes it difficult to expand modern health services, hence effective low-cost delivery medical system is urgently needed (El Kamali et al. 1997).

This is even more pressing because the use and misuse of over the counter anti-malaria remedies like chloroquine to prevent and treat falciparium malaria has led to widespread appearance of resistant parasites (Milliken 1997). This is complicated by the fact that global warming may lead to expansion of areas in which the ambient temperature and climatic conditions are suitable for Plasmodium transmission. Climatic variability has been associated with some of the recent epidemics (Minakawa et al. 2002).

A total of 17 plant species belonging to 17 genera and 13 families were documented and identified as anti-malarial herbal remedies in Northern Peru. Most species used were Asteraceae (3 species, 17.66\%), followed by Fabaceae and Solanaceae (both 2 species, 11.77\%). All other families contributed only one species each to the pharmacopoeia. The most important anti-malarial families are clearly over-represented in comparison to the overall medicinal flora, while some other medicinally important families (e.g. Lamiaceae, Euphorbiaceae, Poaceae, Apiaceae) are completely missing from the anti-malarial portfolio (Bussmann et al. 2006b). In the context of the questionnaires healers and venders often referred to "Fever" when talking about malaria. Fever however included a variety of conditions, from fevers accompanying flu to fever as a result of malaria. Malaria was recognized as a parasitic infection, and treated accordingly, while other plant species were used to treat fever as a symptom, mainly focusing on lowering body temperature.

The majority of anti-malarial herbal preparations were prepared from the leaves of plants $(38.46 \%)$, while the whole plant $(26.92 \%)$, flowers $(15.38 \%)$ and stems $(11.54 \%)$ were used less frequently. Leaves and stems were used more often for malaria treatments than would have been expected in comparison to the overall medicinal preparations found in the region, while seeds of plants were employed much less frequently and other plant parts not at all (Bussmann et al. 2006b). This indicates that the local healers count on a very well developed knowledge about the properties of different plant parts. In almost $70 \%$ of the cases fresh plant material was used to prepare remedies, which differs little from the average herbal preparation mode in Northern Peru. Interestingly, only about $55 \%$ of the remedies were applied orally, while the remaining ones were applied topically. This is little different from the regional average of application. Over half of all remedies were prepared as mixtures of multiple ingredients by boiling plant material either in water or in sugarcane spirit.

The very limited number of plants employed at the Peruvian coast to treat malaria and fevers might on a first glance surprise, if compared to studies from other regions of the country (Kvist et al. 2006; Roumy et al. 2007). However, malaria has always been of relatively minor importance in the coastal desert areas, and thus it is not surprising that few remedies are employed. There are indications that health practices are in the process of changing, and traditional healers start to treat a patient with prepared western remedies (e.g. Aspirin, Primaquin, Malaraquin or Lariam) although plant preparations are still important (Bussmann et al. 2006a; 2007c; 2009a).

Little scientific evidence exists to prove the efficacy of the species employed as malaria remedies in Northern Peru. Only $41 \%$ of the plants found or their congeners have been studied at all for their medicinal properties.

\section{Cancer and Tumors}

Fourty-seven plant species belonging to 42 genera and 30 families were used by curanderos in Northern Peru to treat cancerous conditions and diabetes symptoms. Most species used were Asteraceae (9 species, $19.15 \%$ ), followed by Gentianaceae ( 3 species, $6.37 \%$ ), and 7 familes with 2 species each (4.25\%). All other families contributed only one species each to the pharmacopoeia. Asteraceae as the most important anti-cancer and anti-diabetic family is clearly over-represented in comparison to the overall medicinal flora, while most other medicinally important families are 
either under-represented or completely missing from the portfolio (Bussmann et al. 2006b).

The majority of anti-cancer and anti-diabetic herbal preparations were prepared from the leaves of plants $(30.77 \%)$, while the whole plant $(20 \%)$, stems $(20 \%)$ and flowers $(6.15 \%)$ were used less frequently. Leaves and stems were more often used than characteristic for the overall medicinal preparations found in the region, while whole plants were employed less frequently (Bussmann et al. 2006b). This indicates that the local healers count on a very well developed knowledge about the properties of different plant parts. In almost $60 \%$ of the cases fresh plant material was used to prepare remedies, which differs little from the average herbal preparation mode in Northern Peru. Over $90 \%$ of the remedies were applied orally, while the remaining ones were applied topically. This is significantly different from the regional average of application. More than $50 \%$ of the remedies included multiple plants.

Little scientific evidence exists to date to prove the efficacy of the species employed as anti-cancer and anti-diabetic remedies in Northern Peru. Only $38.71 \%$ of the plants found as diabetes treatments and $17.65 \%$ employed as anti-cancer remedies or related species in the same genus have been studied at all.

\section{Parts of Medicinal Plants Used and Mode of Application}

Northern Peruvian curanderos prefer to use either the leaves (in $25 \%$ of all uses) or the whole plant $(24 \%)$ for the preparation of their remedies. In $19 \%$ of the cases the stems of the plants were used, most commonly together with the leaves. Flowers $(10 \%)$, seeds $(7 \%)$, fruits and roots ( $4 \%$ each), bark $(3 \%)$, fruit peel $(2 \%)$, and latex and wood ( $1 \%$ each) were only used for a small number of preparations.

Almost two-thirds (64\%) of the remedies employed in Northern Peru are prepared using fresh plant material. Many of the introduced species are cultivated in fields and gardens, but the majority of the indigenous species are collected wild. This indicates that a widespread system of plant collectors is needed to supply the fresh plant material needed in Traditional Medicine. Most healers agreed, however, that in most cases dried material could be used if fresh plants were not available. In $36 \%$ of all cases the remedies were prepared using specifically dried plant material. Fresh material was not used in these situations (Bussmann et al. 2006b).

Healers in Northern Peru often employ very sophisticated mixtures of a variety of plants in their treatments. The use of single species for treatments was rare. Most commonly, plant material was boiled in water, or in some cases in sugarcane alcohol (aguardiente) to extract the active compounds. In some cases, plant material was macerated in cane alcohol or wine for longer periods of time before use.

The curanderos all had strikingly exact recipes for treatment, with very specific quantities of plant material used to prepare remedies. These quantities did not differ greatly from one healer to another. Also, the amount of a specific remedy that was given to a patient was very similar among the different curanderos.

The most frequent way to administer remedies was to prepare a decoction and ingest it orally (52\% of all uses) followed by application as a poultice (38\%, plant crushed and/or boiled and applied). Seven percent of all plant uses entailed the preparation of a seguro, a bottle or small flask filled with plant material along with various perfumes. This amulet has to be carried by the patient at all times, or it is placed in the house and used for periodic blessings. Seguros contained anything from a handful to more than three-dozen different ingredients. In two percent of the plant uses the material was employed to fabricate charms, and in one percent of all applications the plant material was burned as incense, with the smoke inhaled for treatment.

Many traditional healers rely on herbal preparations, often consisting of complex ingredients and with very specific preparations, to treat their patients' illnesses, rather than just employing single plant extracts. However, studies documenting these preparations and analyzing the composition of the mixtures are almost nonexistent. Most ethnobotanical studies to date document the "use" of single species, without asking the important question if the plants in 
question are really employed alone, or if they are in fact part of a more complex preparation. Cano et al. (2004) were amongst the first authors to respond to this challenge, and reported on plant mixtures employed in Cuba and the Middle East, and Vandebroek et al. (2010) demonstrated the great complexity of plant preparations in the Dominican Republic. No information however was available for the very species rich Andean pharmacopoeia.

The present publication attempts to give a detailed overview on the herbal mixtures employed by traditional practitioners in Northern Peru and the specific applications they are used for, in order to provide a baseline for more in-depth studies on efficacy and safety of these preparations, as well as the possible applications in the public health system.

The investigation of plant mixtures used in traditional medicine in Northern Peru yielded a total of 974 herbal preparations used to treat 164 different afflictions (Bussmann et al. 2010a). The classification of diseases followed the curandero's terminology. To allow a better overview the different disease concepts were grouped in more inclusive disease categories, according to their similarity. Psychosomatic disorders were the most outstanding afflictions treated with traditional herbal mixtures, with almost $30 \%$ of all recipes applied, followed by respiratory illnesses, female issues, kidney problems and heart problems. Susto (fright), problems of the nervous system, general systemic inflammation and bronchitis together accounted for almost $25 \%$ of all remedies used. In many cases, healers used only one or two common mixtures to treat an illness. This degree of consensus between different healers shows great sophistication in the diagnosis and treatment of specific disorders. On the contrary, when it came to the treatment of unspecific disease categories like "inflammation" or "bronchitis", every healer seemed to use her/his own specific mixture to treat the problem. This was particularly obvious in the treatment of neurological and psychosomatic problems, for which the majority of plants and mixtures was employed. Up to 49 different preparations were used to treat the same disease. This seems to indicate a high degree of experimentation that is still ongoing in order to find a working cure for unspecific symptoms, and that there is very little consent amongst the individual healers as which cure to employ. This low consensus, especially where spiritual and nervous system / psychosomatic aspects are involved, might also indicate that the individual healers are reluctant to exchange knowledge about their dedicated, specific and guarded treatment methodology in these areas, while the knowledge about "simple" treatments is much more widespread..

Altogether 330 plant species, representing almost $65 \%$ of the medicinal flora used in the region (Bussmann et al. 2010a) were applied in mixtures. Of these, 64 species (19.39\%) were introductions, which falls within the range of introduced species as percentage of the whole medicinally used flora. Amongst the plants employed, Asteraceae expectedly stood out, and the number of species of this family used was comparable to the percentage of Asteraceae in the medicinal flora of the region (Bussmann \& Sharon 2006). The overwhelming number of plant mixtures contained 2-7 different plant species, although in the most extreme case 27 distinct species were included. A large number of species appeared in various mixtures. The plant species for each mixture are listed in the order given by the curanderos in order to express the importance of the individual species, rather than providing an alphabetical listing. For a detailed overview on quantities and parts of each plant use see (Bussmann et al. 2006b).

The cluster analysis confirmed that mixtures used for applications like inflammations, infections and blood purification, as well as cough, cold, bronchitis or other respiratory disorders, or urinary infection and kidney problems had similar floristic compositions. However, a few interesting clusters stood out: Mixtures used for nervous system disorders, anxiety and heart problems often had a similar composition for example, as did mixtures for prostate and bladder problems; kidney problems, gallbladder disorders, diabetes and cholesterol were treated with the same preparations; as were rheumatic illnesses and asthma. Our research suggests that this indicates that the local healers have a very detailed understanding of disease concepts, and are choosing their remedies very 
carefully, based on what underlying cause they diagnose, i.e. heart problems get treated differently if they are caused by stress, versus a physical agent, kidney infections are treated differently from kidney problems linked to diabetes and/or obesity.

The floristic composition as well as the complex phytochemistry of traditional herbal mixtures remain woefully understudied. This is the more surprising as traditional one-plant one single-compound based drug discovery efforts have yielded very little results in the last decades, and might in fact be an explanation as to why so many plant species that have been documented for a certain use, are "inefficient" or "toxic" when introduced to clinical trials.

Our research indicates that a large number of plants used in traditional healing in Northern Peru are employed in often-sophisticated mixtures, rather than as individual plants. Peruvian curanderos appear to employ very specific guidelines in the preparation of these cocktails, and seem to have a clear understanding of disease concepts when they diagnose a patient, which in turn leads them to often apply specific mixtures for specific conditions. There seems to be a widespread exchange of knowledge about mixtures for treatment of bodily diseases, while mixtures for spiritual, nervous system and psychosomatic disorders appear to be more closely guarded by the individual healers.

Traditional herbal mixtures, with their wealth of compound fragments and new compounds originating in the preparation process, could well yield new clues to the treatment of a wide variety of disease. The present paper provides detailed baseline information on composition and use of traditional mixtures in Northern Peru, and further studies to compare the compound composition of these preparations versus single plant extracts, as well as investigations comparing efficacy and toxicity of herbal preparations versus their single plant ingredients are in progress.

\section{Does traditional medicine work? A look at antibacterials used in Northern Peru}

Plants with potential medicinal activity have recently come to the attention of Western scientists, and studies have reported that some are bioactive
(Perumal Samy et al. 2000). Potentially active compounds have been isolated from a few of the plants tested (D'Agostino et al. 1995 a,b; Okuyama et al. 1994, Rodriguez et al. 1994).

In order to evaluate the antibacterial activity of species used in TM in Northern Peru, 525 plant samples of at least 405 species were tested in simple agar-bioassays for antibacterial activity against Staphylococcus aureus, Escherichia coli, Salmonella enterica Typhi and Pseudomonas aeruginosa. A much larger number of ethanolic plant extracts showed any antibacterial activity compared to water extracts for all antibacterial activity. One-hundred-ninety-three ethanolic extracts and 31 water extracts were active against $S$. aureus. In twenty-one cases only the water extract showed activity (for all bacterial species) compared to ethanol only. None of the aqueous extracts were active against the other three bacteria, with the activity of the ethanolic extracts also much reduced, as only 36 showed any activity against $E$. coli, and 3 each against $S$. enterica Typhi and $P$. aeruginosa. Eighteen ethanol extracts were effective against both $E$. coli and $S$. aureus, while in two cases the ethanol extract showed activity against $E$. coli and the water extract against $S$. aureus. The ethanol extract of Dioscorea trifida was effective against E. coli, S. aureus and P. aeruginosa. Caesalpinia spinosa was the only species that showed high activity against all bacteria, including Salmonella enterica Typhi and Pseudomonas aeruginosa, when extracted in ethanol (Bussmann et al. 2010b).

Two hundred twenty-five extracts came from plant species that are traditionally employed against bacterial infections. One hundred sixty-six $(73.8 \%)$ of these were active against at least one bacterium. Of the three hundred extracts from plants without traditional antibacterial use, only $96(32 \%)$ showed any activity. This shows clearly that plants traditionally used as antibacterial had a much higher likelihood to be antibacterially active than plants without traditional anti-bacterial use. However, the efficacy of plants used traditionally for antibacterial related applications did vary, which underlines the need for studies aiming to clearly understand traditional disease concepts. Plants used for respiratory disorders, inflammation/ infection, wounds, diarrhea, and to prevent post- 
partum infections were efficacious in $70-88 \%$ of the tests. Plants used for "kidney inflammation" had a much lower efficacy against bacteria, and fell within the range of species that are traditionally used to treat other bodily disorders. Only species used for spiritual/ritual treatments scored worse. Of these only $22 \%$ showed some antibacterial; activity. However, amongst the "spiritual" plants $38 \%$ of the species used for cleansing baths did in fact show activity, while only $15 \%$ of the plants often used in protective amulets (mostly species with the families of Lycopodiaceae and Valerianaceae) showed limited antibacterial activity.

A variety of species showed higher efficacy than the control antibiotics employed, e.g. Ambrosia peruviana, Iresine herbstii, Niphogeton dissecta, Opuntia ficus-indica, Smilax kunthii were particular effective against Escherichia coli. Berberis buceronis, Caesalpinia paipai, Caesalpinia spinosa, Cestrum strigilatum, Cydista aequinoctialis, Dioscorea trifida, Escallonia pendula, Escobedia grandiflora, Eucalyptus citriodora, Eucalyptus globulus, Eugenia obtusifolia, Eustephia coccinea, Gallesia integrifolia, Geranium sessiliflorum, Hedyosmum racemosum, Iresine herbstii, Lycopersicon hirsutum, Mauria heterophylla, Phyllanthus niuriri, Porophyllum ruderale, Salvia cuspidata, Senecio chionogeton, Smilax kunthii, Tagetes erecta and Taraxacum officinale showed high activity against Staphylococcus aureus. The same holds true for Ephedra americana, Gentianella bicolor, Mandevilla cf. trianae. However, extracts of these three species were highly inconsistent in their efficacy.

The comparison of closely related species traditionally employed for different purposes (e.g. different Alternanthera spp., Passiflora spp., Senecio spp. and Salvia spp. for spiritual purposes and against bacterial infections) showed that the "spiritual" species normally were not effective against bacteria, while the species used as antibacterials had increased effectiveness. The example of Plantago sericea var. sericea (used in seguros, no efficacy) and Plantago sericea var. lanuginosa (used for vaginal infections, high efficacy against $S$. aureus) is a particularly compelling case that indicates the sophistication of traditional knowledge. However, we did find examples like Chuquiragua spp., where closely related species were used as antibacterials, but only one of them did in fact show efficacy, clearly indicating that in this case traditional knowledge did not produce reliable results.

On the other hand, extracts of the same species traditionally used to treat infections often produced vastly diverging results when collected from different localities. Good examples are Iresine herbstii, Schinus molle, Eustephia coccinea, Oreopanax eriocephalus, Myroxylum balsamum, Spartium junceum, or Gentianella dianthoides. Most of these species did not produce particularly high inhibition rates in any case, and were not the first choice of healers when trying to find remedies for bacterial infections. Many traditional remedies for concepts like "kidney inflammation" did not produce any antibacterial results, which underlines that research into efficacy does need to closely take traditional disease concepts into account.

Many remedies used for spiritual healing and other non-infection purposes did show antibacterial efficacy in vitro, but were not listed as such by the local healers. This might be explained by the fact that they either are very inconsistent in their activity (e.g. Mandevilla trianae, Loricaria spp., Lonicera japonica, Hypericum laricifolium, Hyptis sidifolia, Mentha piperita, Brachyotum naudinii, Cydonia oblonga), or are so closely related that identification, especially when dried, can be a problem, e.g. in the case of Baccaris spp., Gentianella spp., and Valeriana spp., or are prone to toxic side effects like Ephedra americana and Brugmansia spp.

Almost all remedies are traditionally prepared as water extracts, although ethanol (in the form of sugarcane spirit) is readily available. This might at a first glance seem astonishing, given the low efficacy of water extraction found in this study. However, initial results from Brine-Shrimp toxicity assays indicate that the ethanolic extracts are by far more toxic than water extracts of many species, and thus ethanolic extraction might in many cases not e suitable for application in patients. This again indicates the considerable sophistication and care with which traditional healers in northern Peru chose their remedies for a specific purpose.

If the botanical documentation of Peruvian medicinal plants has been neglected, investigations 
of the phytochemical composition of useful plants is lagging even further behind. Most studies on the phytochemistry of Peruvian plants concentrate on a few "fashionable" species that have been marketed heavily on a global scale, especially Maca (Lepidium meyenii), Sangre del Drago or del Grado (Croton lechleri), and Uña de Gato (Uncaria tomentosa and Uncaria guianensis). The number of other Peruvian plants for which at least some phytochemical studies exist is still miniscule, and most efforts are fuelled by the fads and fashions of the international herbal supplement market. Studies involving multiple species were initiated as late as the 1990s.

Minimum inhibitory concentrations foud for Peruvian plant extracts ranged from 0.008 to $256 \mathrm{mg} / \mathrm{ml}$. The very high values in many species indicate only a very limited antibacterial efficacy. The ethanolic extracts exhibited stronger activity and a much broader spectrum of action than the water extracts. The most interesting activity on E. coli was obtained from ethanolic extracts of Baccaris sp., Ochroma pyramidale, Croton lechleri, Banisteriopsis caapii, Miconia salicifolia, and Eugenia obtusifolia. Only the latter species also showed strong activity in the aqueous extract. A much wider range of species, including most species active against $E$. coli showed inhibition of $S$. aureus. Poropohyllum ruderale, Senecio sp., Corynaeae crassa, Dioscorea trifida, Senna monilifera, Spartium junceum, Pelargonium odoratissimum, Satureja pulchella, Cuphea sp., Malva parviflora, Brosmium rufescens, Syzygium aromaticum, Sanguisorba minor, Citrus limetta, Verbesine sp. and 2 unidentified species all showed MIC values between $1-4 \mathrm{mg} / \mathrm{ml}$. Most of them however did not portray any efficacy in aqueous extract. Hypericum laricifolium, Hura crepitans, Caesalpinia paipai, Cassia fistula, Hyptis sidifolia, Salvia sp., Banisteriopsis caapi, Miconia salicifolia and Polygonum hydropiperoides showed the lowest MIC values and would be interesting candidates for future research (Bussmann et al. 2010b).

Most species effective against $S$. aureus are traditionally used to treat wound infection, throat infections, serious inflammations, or are post partum infections. Interestingly many species used in cleansing baths also showed high activity against this bacterium. Many of these species are either employed topically, or in synergistic mixtures, so that possible toxicity seems not to be an issue. The species effective against $E$. coli were mostly employed in indications that traditional healers identified as "inflammation".

Most of the plants used by the healers have antibacterial activity, but only 8 of the 141 plants $(5.6 \%)$ examined in this study show any MIC values of 200 or less $\mathrm{mg} / \mathrm{ml}$ of extract. Of these 8 plants 5 are used to treat diseases believed to be in bacterial origin by $\mathrm{TM}$, one is a disease not believed to be caused by bacteria and one is used for undefined treatment purposes.

Nine out of 141 plants (6.3\%) tested that were not used for diseases believed to be bacterial in origin by TM, 5 showed high antibacterial activity with MIC values below $16 \mathrm{mg} / \mathrm{ml}$. Four of these were among the most potent plants tested with MIC values of 2 or less $\mathrm{mg} / \mathrm{ml}$ including the hallucinogen and extracts used to treat diabetes and epilepsy. Diseases such as diabetes often compromise the health of the individual and antibacterial treatments can be warranted for secondary complications of the disease.

\section{Toxicity in Traditional Medicine}

Crude medicinal activities have been investigated for a wide variety of plants, but while toxicity assays are available for a wide variety of countries no data exists on the potential toxicity of Peruvian medicinal species.

Brine shrimp (Artemia) are frequently used as agent in laboratory assays to determine toxicity values by estimating $\mathrm{LC}_{50}$ values (median lethal concentration). The Brine shrimp lethality activity of 501 aqueous and ethanolic extracts of 341 plant species belonging to 218 genera of 91 families used in Peruvian traditional medicine was tested (Bussmann et al. 2011). The aqueous extracts of 55 species showed high toxicity values $\left(\mathrm{LC}_{50}\right.$ below $249 \mu \mathrm{g} / \mathrm{ml}), 18$ species showed median toxicity $\left(\mathrm{LC}_{50} 250-499 \mu \mathrm{g} / \mathrm{ml}\right)$ and 18 low toxicity $\left(\mathrm{LC}_{50} 500\right.$ $1000 \mu \mathrm{g} / \mathrm{ml})$. The alcoholic extracts proved to be much more toxic: 220 species showed high toxicity values $\left(\mathrm{LC}_{50}\right.$ below $249 \mu \mathrm{g} / \mathrm{ml}$, with 37 species having toxicity levels of $>1 \mu \mathrm{g} / \mathrm{ml}), 43$ species showed median toxicity $\left(\mathrm{LC}_{50} 250-499 \mu \mathrm{g} / \mathrm{ml}\right)$ and 23 
species low toxicity $\left(\mathrm{LC}_{50} 500-1000 \mu \mathrm{g} / \mathrm{ml}\right)$. Over $24 \%$ of the aqueous extracts and $76 \%$ of the alcoholic extracts showed elevated toxicity levels to brineshrimp. Traditional preparation methods are taking this into account - most remedies are prepared as simple water extracts, thus avoiding potential toxic effects. Excellent examples where the water extracts are non-toxic, while the ethanolic extracts show high toxicity are Ocimum basilicum L., Salvia sp., or Laccopetalum giganteum (Wedd.) Ulbrich. In contrast, Cinchona officinalis $L$. ethanolic extracts were non-toxic, and are traditionally used, while the highly toxic water extract has no traditional use.

Species which showed higher levels of toxicity were Bejaria aestuans L., Erodium cicutarium (L.) L'Her., Brachyotum naudinii Triana, Miconia salicifolia (Bonp. ex Naud.) Naud., Cuscuta foetida Kunth, Caesalpinia spinosa (Molina) Kuntze, and Phyllactis rigida (Humb. and Bonpl.) Pers.. Achillea millefolium L., Artemisia absinhitum L., and Eucalyptus globulus Labill all frequently used as medicinal teas also fall in this group, as do Lupinus mutabilis Sweet, and Ilicium verum Hook. f. Solanaceae (e.g. Nicotiana tabacum L. and Solanum americanum Mill.) proved highly toxic, while other species, known to be highly toxic when ingested (e.g. Datura sp. and Brugmansia spp.) did not show toxicity in Brine Shrimp.

Multiple extracts from different collections of the same species showed in most cases very similar toxicity values. However, in some cases the toxicity of extracts from different collections of the same species varied from non-toxic to highly toxic. Examples for such variation in toxicity were found for Chersodoma deltoidea M.O. Dillon and Sagast., Satureja sericea (C. Presl. and Benth.) Briq., Eugenia obtusifolia Cambess., Epidendrum sp., Capparis crotonoides Kunth, Sambucus peruviana Kunth, and Malva sp. In case of these frequently used species, harvest time, collection locality or use of specific plant parts might be important for a reduction of toxicity.

\section{Markets and Sustainability}

The pharmacopoeae of Southern Ecuador and Northern Peru - Colonial regimes and their influence on plant use
The differences in medicinal plant use between Southern Ecuador and Northern Peru are striking. Both regions share the same cultural background, and have a very similar flora, with a comparable number of plantspecies that to a large extent overlap. Many plants mentuioned in Martinez Compañon (1789) are still found in local markets today (Fig. 6). However, the medicinal flora of Southern Ecuador includes only $40 \%$ of the species used in Northern Peru. The differences in traditional medicinal use can be explained by comparing the development of the pharmacopoeiae of both areas from the start of the colonial period until today. Colonial chroniclers often included detailed descriptions of useful plants in their reports. The most comprehensive early accounts of the economically interesting flora of Northern Peru and Southern Ecuador were provided by Monardes (1574), Acosta (1590), and Cobo $(1653,1965)$. Later treatments were included in Alcedo (1776). Martínez Compañon, Archbishop of Trujillo, had a complete inventory of his dioceses prepared (1789). Finally, Ruiz and Pavón provided the first real botanical inventory of the region (1777-1788). The account of Martínez Compañon (1789) provides the best baseline for a comparison of the colonial and modern medicinal flora of the region. The work includes detailed paintings for every species, which allows a close comparison with the modern medicinal flora, indicating that the vernacular names of useful plants have not changed significantly since colonial times. It contains 526 useful plant species. A preliminary review of this work seems to indicate that the number of plants used has not changed significantly since the late 1700's, with over 500 plant species still found in modern Peruvian markets. A closer comparison shows, however, that only $41 \%$ of the species mentioned by Martinez Compañon (1789) are still sold nowadays in Peru. An additional $32 \%$ are still used in the Amazon basin, but do not reach the coastal markets anymore. Twenty-seven percent have completely disappeared from modern day use. This means that $58 \%$ of the species sold in Peruvian markets and $41 \%$ of the species used in Ecuador were added to the pharmacopoeia within the last 200 years (Fig. 7). 


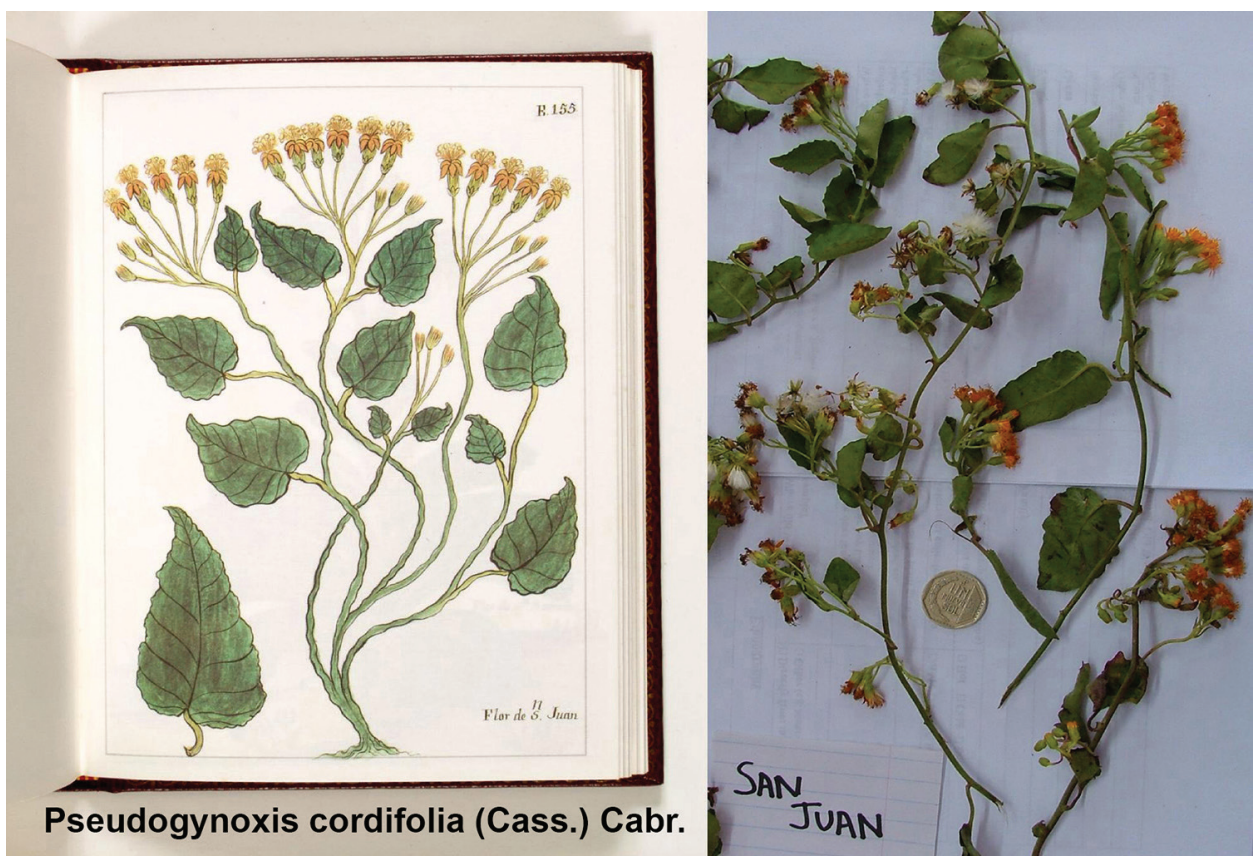

Figure 6. Flor de San Juan from drawing in Martinez Compañon (1789) and recent market purchase.

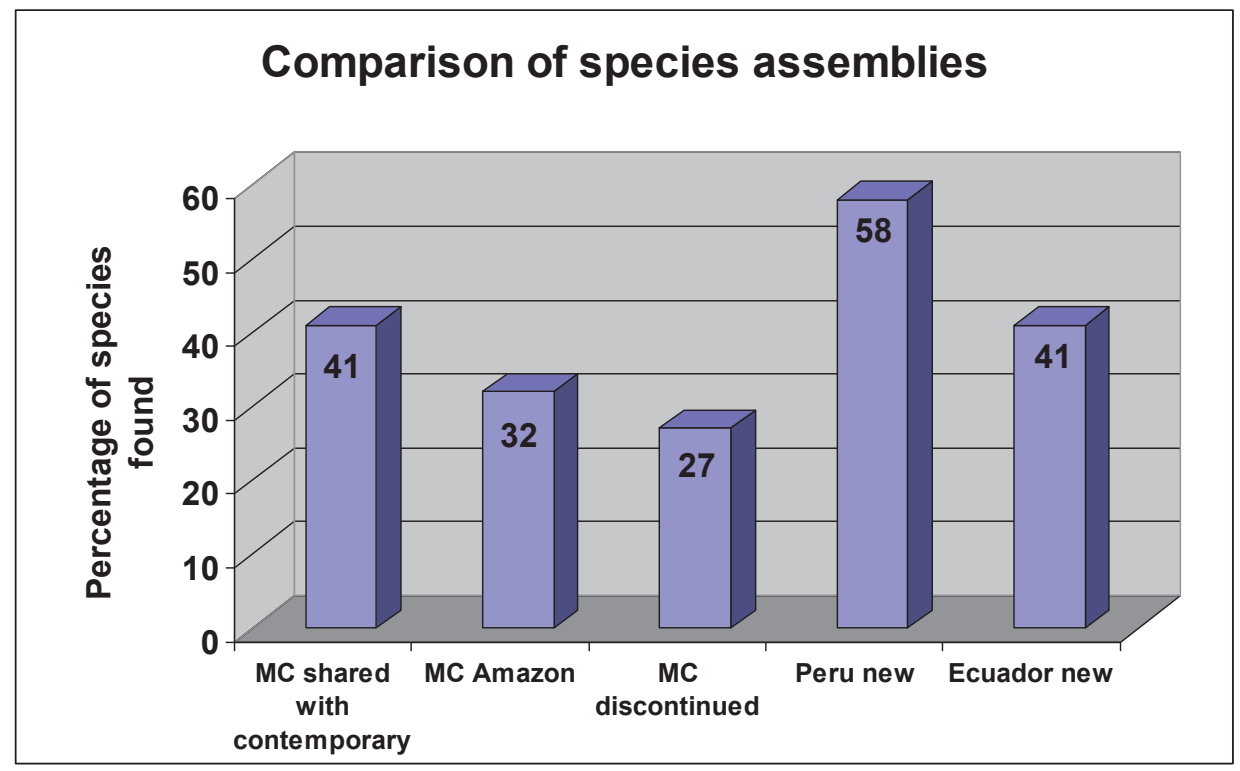

Figure 7. Differences in plant usage between Peru and Ecuador.

A cluster analysis of the colonial and modern plant inventories showed a striking explanation for the use differences between Ecuador and Peru, and helps to explain why the plant inventories changed so significantly in the $18^{\text {th }}$ century: The current pharmacopoeia of useful flora in Ecuador was most similar to the early colonial flora mentioned in
Monardes (1574), Acosta (1590), Cobo $(1653,1956)$ and Alcedo (1776). This indicates that the Ecuadorian medicinal flora did not develop much between early and late colonial times. In contrast, the modern Peruvian healing flora was much more similar to later collections (Fig. 8). An explanation for this lies in the different treatment of traditional practices in 
Ecuador and Peru: In Ecuador, traditional medicinal practitioners were immediately persecuted once the colonial administration took hold, while the Peruvian administration was much more tolerant. This also reflects in the establishment of a National Institute for Traditional Medicine in Peru in the 1980s, while traditional medicine was illegal in Ecuador, until a constitutional change in 1998. This meant that Ecuadorian healers had no opportunity to experiment with new species to cure diseases introduced by Europeans, while Peruvian healers were able to explore the rich flora of the region in order to find new remedies. This experimentation also extended to "magical" disease concepts like Mal Aire, Mal Ojo, Susto, and Envidia that were introduced from Spain during the colonial regime. Peruvian healers developed a vast array of medicinals to treat these conditions, which, to a large extent explains the shift in the medicinal flora between the late 1700 s and modern times. Experimentation in Ecuador remained restricted to the treatment of common diseases, while spiritual treatments were outlawed until a constitutional revision in 1998 recognized the right of the population to use traditional medicinal practices (Fig. 9) (Bussmann et al. 20009e).

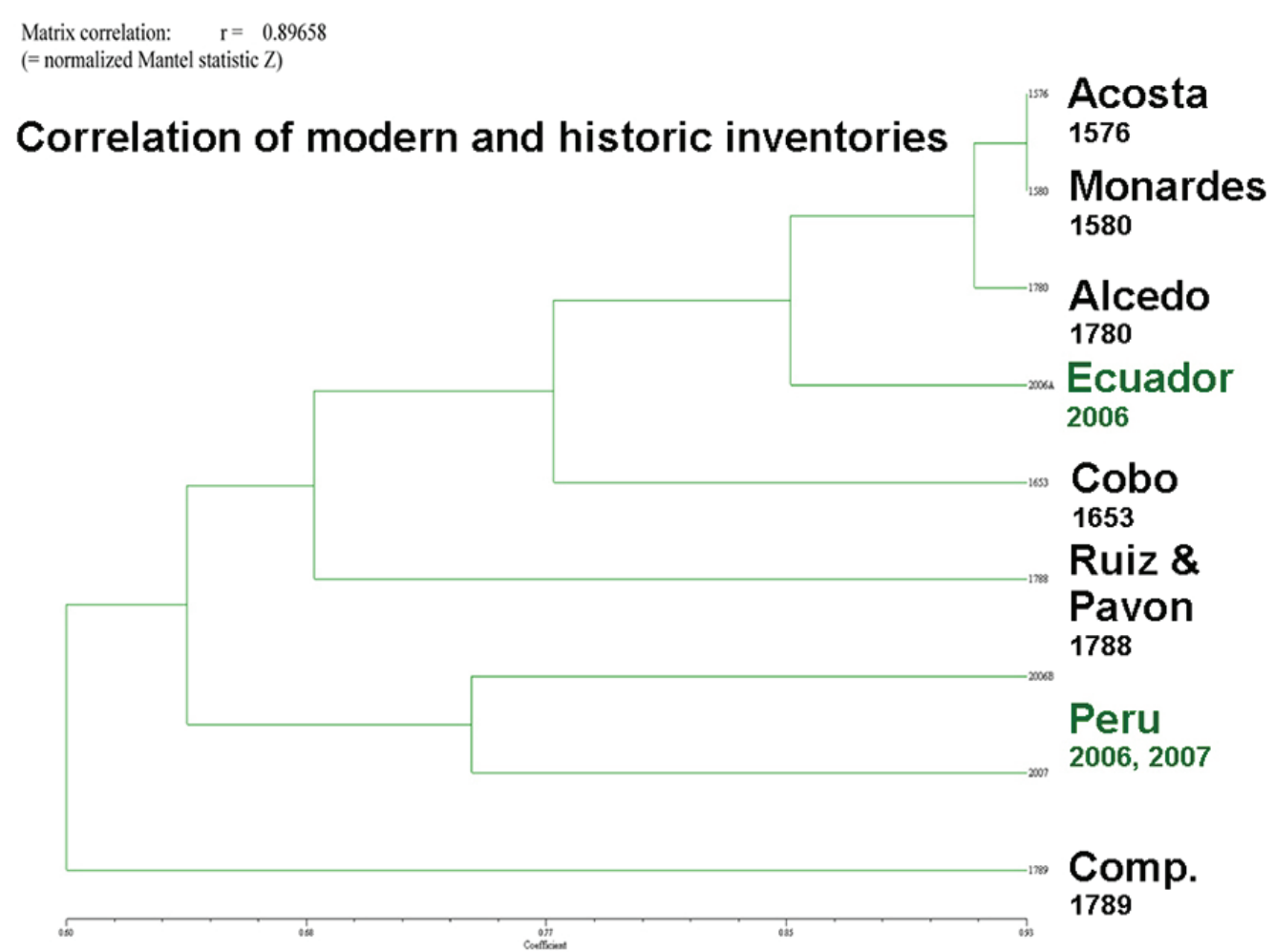

Figure 8. Cladogram of linkage of historic sources and current pharmacopoeiae 


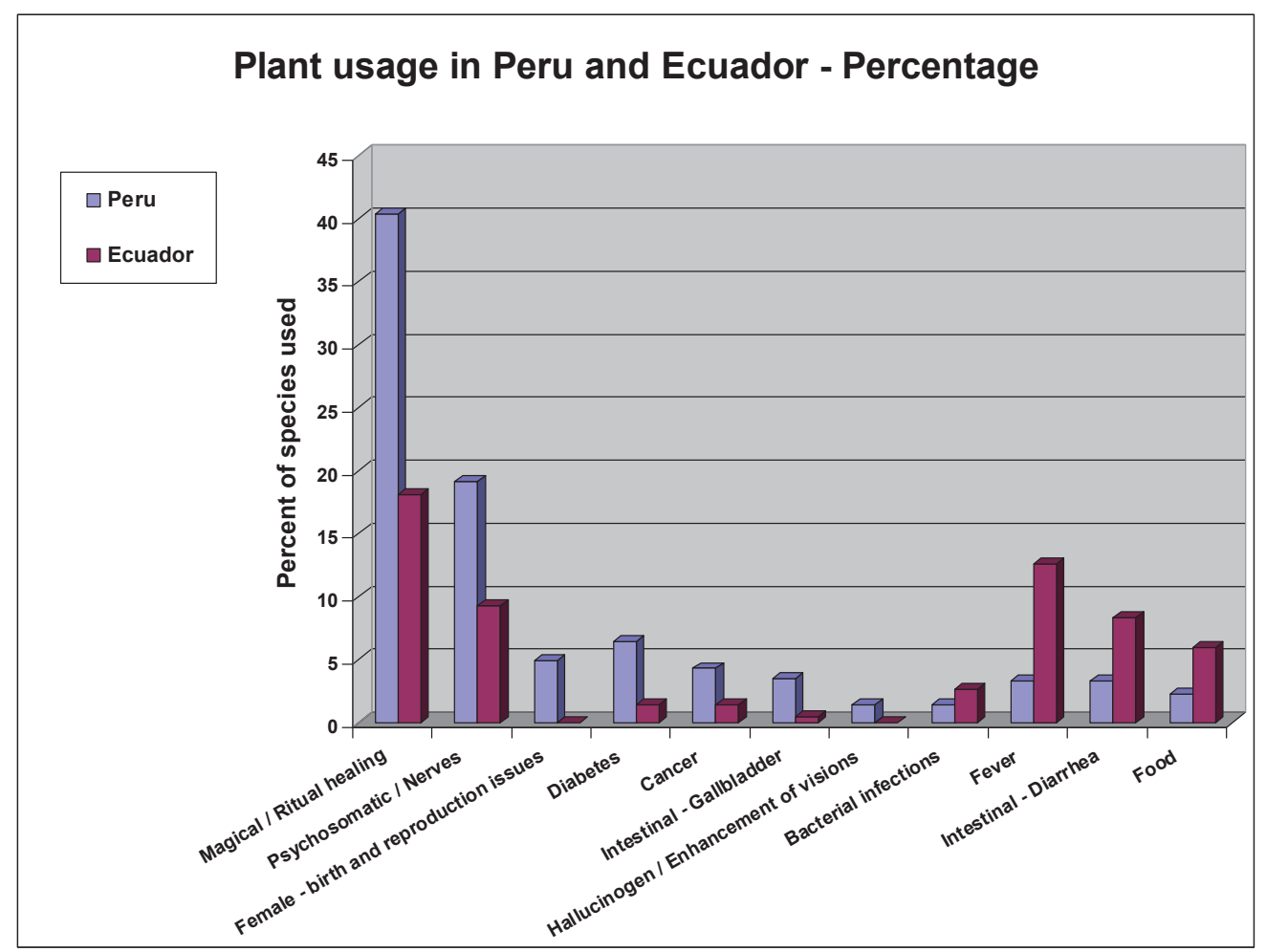

Figure 9. Plant use differences in Ecuador and Peru

\section{THE CASE OF ULLUCHU}

Ulluchu is the common name assigned to a plant frequently depicted in the art of the Moche culture, which thrived on the north coast of Peru from A.D. 100 to 800 . It is a grooved, commashaped fruit with an enlarged calyx found mainly in fine-line scenes painted on Moche ceramics (Fig. 10). The term first appeared without linguistic explanation in the work of pioneer Moche scholar Rafael Larco Hoyle [1939: Fig. 58; 1940: 98, Figs. 166 \& 167]. In his 1939 publication, he reported that the peoples of the sierras and the coastal region (Viru and Moche valleys) believed that the fruit had to be picked silently to prevent it from turning bitter. He wondered if the plant symbolized the silence and discretion of richly attired Moche messengers, some of whom wear belts adorned with Ulluchus. In his 1938 publication, he labeled a Moche fineline drawing of Ulluchu as Phaseolus sp. (a bean). Larco clearly recognized that Ulluchu had nothing whatsoever in common with "ulluco" (Ullucus tuberosus), and Andean tuber still widely cultivated and consumed in Peru nowadays. 

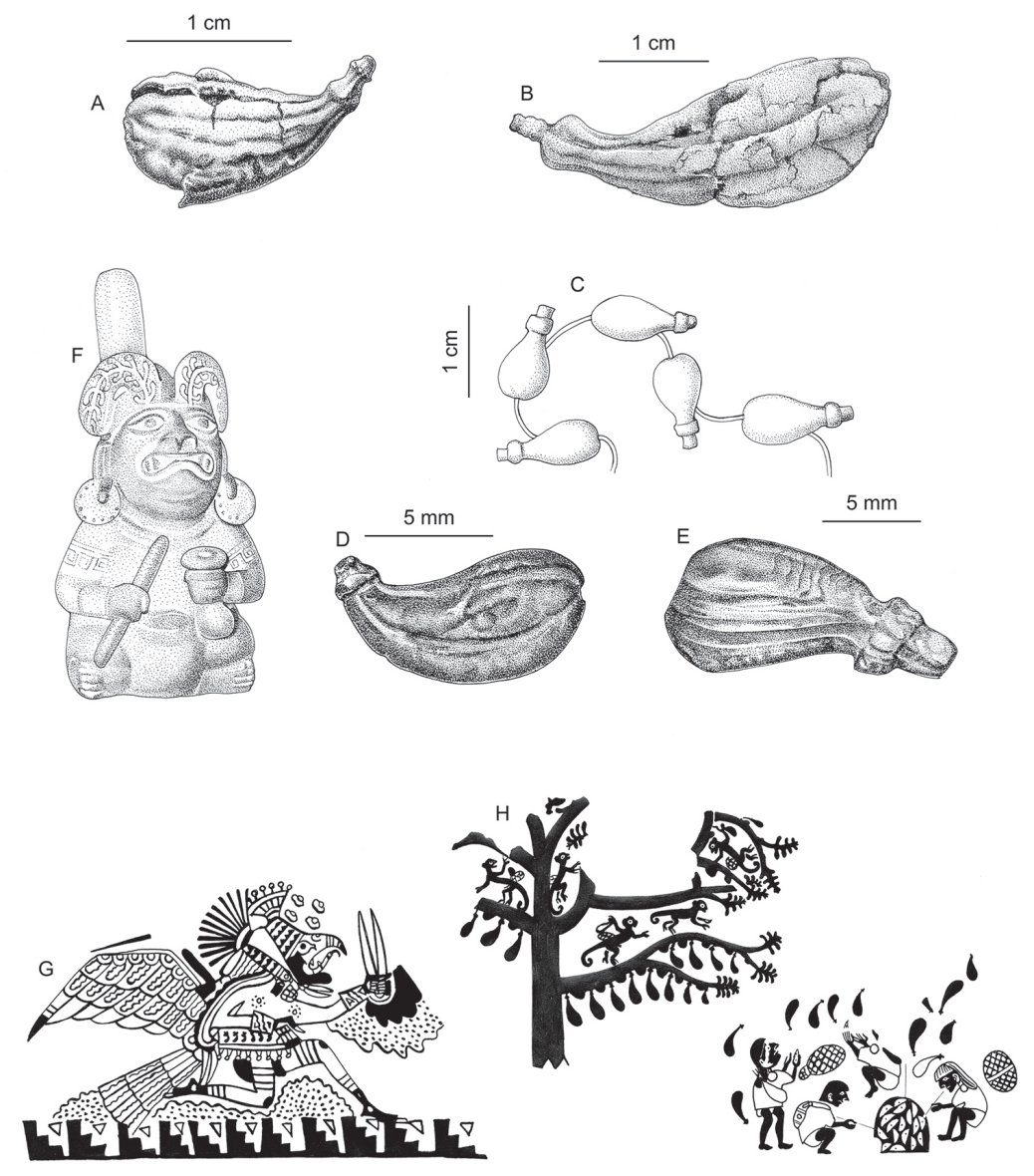

Figure 10. Ulluchu in Archaeology

A. Ulluchu fruit from cache at Sipán. After photograph by Christopher B. Donnan. B. Ulluchu fruit from Dos Cabezas burial;, after photograph from Donald McClelland. C. Bone beads in form of Ulluchus fron Huaca de la Luna. After photograph of Donald McClelland. D. Golden Ullucho bead, after photograph by Donald McClelland. E. Spondylus shell bead in form of Ulluchu. After photograph by Donald McClelland. F. Supernatural figure seated holding a gourd, possibly containing ground Ulluchu seeds. Ulluchus painted on headdress. Private collection. After photograph by Christopher B. Donnan, from McClelland (McClelland 2008). G. Anthropomorphized hawk runners. Ulluchu on belts, Ulluchu seeds floating above, runner carrying snuff tube. The Art Institute of Chicago. After drawing by Donna McClelland (McClelland 2008). H. Ulluchu harvest. Note tree with opposite leaves, and extracted seeds on bottom right. After McClelland (2008), Private collection.

The symbolic importance of Ulluchu in Moche iconography was firmly established by Moche scholar Donnan McClelland (1977). Based upon a meticulous review of the UCLA Moche Archive, she showed that its distribution was non-random and that its varied usage displayed definite patterns with the greatest variability among background elements and the most frequent representation found on the belts of warriors and runners. She demonstrated that "the leaves of the Phaseolus do not resemble the ulluchu leaf depictions"
(McClelland 1977: 43) Pepino (Solanum muricatum) and aji (Capsicum annum), which are clearly depicted in Moche art and do not resemble Ulluchu were also eliminated "since the ulluchi [sic] fruit is suspended from the plant by its smaller pointed end, whereas these two are suspended by the large end" (McClelland 1977: 437). She also indicated that the plant had not been botanically identified, pointing out that, if it turned out to be a mythical plant, no identification would be possible. 
A decade after McClelland's seminal article, S. Henry Wassen (1987) of the Gothenburg Ethnographical Museum, eliminated Persea americana Miller var. americana (a wild relative of avocado) as a candidate, and concluded that Ulluchu was Carica candicans A. Gray (a species of wild papaya). He also co-authored an article describing the enzyme papain, which can be extracted from unripe papaya, for use as a blood anti-coagulant (Hulten et al. 1987). In the latter article, the authors proposed that papain was used in the Moche sacrifice ceremony to prevent the coagulation of blood drawn from sacrificed warriors for later consumption by priests.

In a paper presented at the Sibley Conference at the University of Texas at Austin, in November 2003, McClelland (2008), in addition to updating her 1977 paper in the light of a vastly expanded Moche Archive and archaeological discoveries of real Ulluchu, refuted the papaya hypothesis. She also discussed the presence in the art of yellow oleander seeds (Thevetia peruviana) as legging rattles as well as espingo seeds (Nectandra sp.) which (wassen 1976) had earlier suggested might have been added to corn beer for medicinal and psychotropic purposes. McClelland concluded that the largest remaining challenge was an identification of Ulluchu.

\section{Issues surrounding the name Ulluchu}

The name Ulluchu seems to have been coined by Larco (1939). According to his description, the name originated in the Virú River valley, and is supposedly of Mochica origin. However, there is no linguistic evidence that such a term indeed existed in the Mochica or Yunga language. The most comprehensive Mochica-Spanish dictionary available, compiled from the writings of Moche scholar E. Brüning (2004), has no such term. In addition, the local population, as well as market vendors, plant collectors, and curanderos interviewed, had no knowledge of Ulluchu whatsoever, other than what they derived from Larco. Since this first publication the term has been copied by all subsequent authors (McClelland 1977, Wassen 1987), without any regard to its validity. It is unlikely that Brüning (2004) would have missed the name when doing his research early in the $20^{\text {th }}$ century, if it indeed was still being. Brüning lists quite a few Mochica plant names, some of which are still used for the same plants today, e.g. "faik" = Acacia macracantha (faique, espino), from "fáçek, fáçke" = spine.

The only language that has a somewhat similar word from which Ulluchu could be derived is Quechua: "uchu" translates to "chili, pepper," while "ullu" translates as "penis." The term "ullu uchu" is sometimes used as a name for Columellia ovata R. \& P. (Columelliaceae), a small high-Andean plant, described as "a very thick tree; its wood is suitable for various purposes, and its leaves have febrifugal properties and are very bitter" (Ruiz 1777). However, this plant has no likeness whatsoever to the Moche Ulluchu. Thus we must conclude that the term Ulluchu was most likely coined by Larco (1940: 98) based on a Quechua term for a species with somewhat similar fruits that has no relation to the species used by the Moche.

\section{Botanical identification: Why is Ulluchu not Carica candicans?}

Carica candicans is a wild relative of papaya (Carica papaya L.). Although the fruits are not marketed, they are occasionally consumed by the local population, and some market vendors and healers interviewed did know the plant under its vernacular name, "mito." Larco $(1939 ; 1940)$ never mentions the plant in relation to Ulluchu. Assuming that he indeed encountered a plant with that name, it cannot have been $C$. candicans, because this species would have been named "mito."

McClelland (2004) argues that Ulluchu "cannot be a papaya, which belongs to a group of plants called 'cauliflory' [i.e., stem flowery]. . . . The flowers and fruit of a cauliflory grow on the trunk of the tree and not on the limbs.... Ulluchus depicted in Moche art, however, hang from limbs. Papaya leaves do not resemble ulluchu leaves, which are triangular, ovoid, or boomerang shapes hanging from limbs. Each large palmate papaya leaf grows on a stem from the top of the tree." However, further complicating this matter, it turns out that C. candicans happens to be one of the few papayas that are not cauliflorous, that have triangular leaves 
with entire margins, and the fruits do hang from branches. Thus, judging from the iconography alone, $C$. candicans actually could be Ulluchu.

Based on recent archaeological evidence however (Fig. 11), (McClelland 2008; Alva et al. 1993; Alva 1994; Donnan et al. 1994), it has become clear that the actual fruits found in burials do not resemble $C$. candicans. In addition, the explanation that papain, might have been extracted by the Moche from unripe papaya for use as a blood anticoagulant (Hultin ert al. 1987), albeit reasonable, does not make much sense from a phytochemical perspective. Cultivated papaya (C. papaya) is often depicted in Moche pottery, and the species contains large amounts of papain. Why would the Moche have resorted to a rare wild species, when they could have used a cultivar with the same properties that grew on their very doorstep? Also, C. candicans fruits are often $10-15 \mathrm{~cm}$. long, and, while this would relate to the size of some of the Ulluchus in the iconography, it is vastly larger than many of the fruits depicted and much larger than the fruits found in burials. Finally, the anatomy of $C$. candicans simply does not correlate with the fruits encountered in burials.

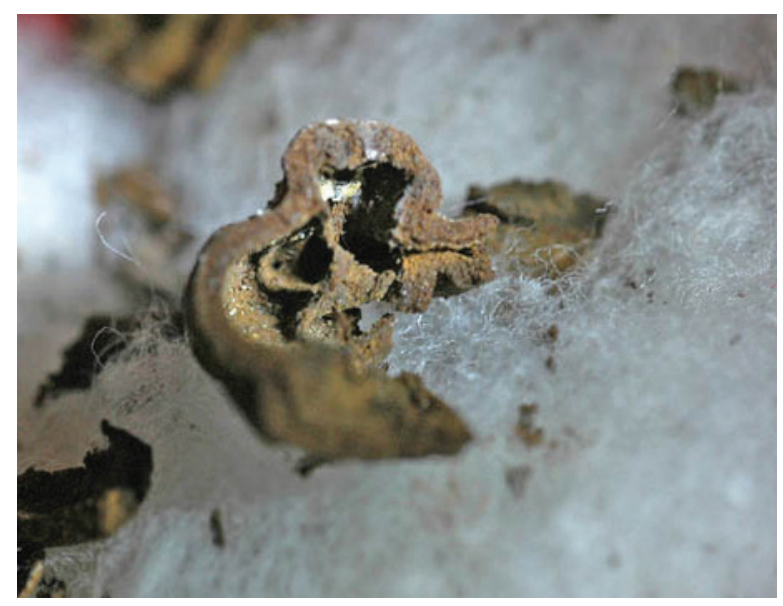

Figure 11. Front view of crushed Ulluchu. Photo Don McClelland.

\section{What is Ulluchu, and what was it really used for?}

Moche fine-line drawings of Ulluchu normally depict seed pods or seeds floating in the air in sacrificial scenes (McClelland 2008: Fig. 3.14), associated with runners and messengers e.g., McClelland 2008: Fig. 3.1) or intoxicated priests (e.g., McClelland 2008: Fig. 3.6). The Ulluchu fruits vary greatly in size, ranging from about $1-15 \mathrm{~cm}$. They are normally comma-shaped, often with an "exaggerated round calyx" [6: 43] with lines on the body of the fruit (e.g. McClelland 2008: Fig. 3.4). Some illustrations show Ulluchu harvested by monkeys, and in such cases the fruit is mostly shown growing along the axes of the plant's leaves (e.g., McClelland 2008: Figs. 3.27 \& 3.28).

Starting from this basis in 2002, we built on the work of Donna McClelland and the archaeological excavations at Sipán in the Lambayeque Valley (McClelland 2008; Alva 1994; Alva et al. 1994) and at Dos Cabezas in the Jequetepeque Valley in the 1990s (McClelland 2008; Donnan 1994). Botanically, all these depictions resemble capsules or drupelike fruits. It became apparent that in a biodiversity hotspot like Peru, with a flora of more than 18.000 species, a large number of plant families have fruits that vaguely resemble Moche fineline drawings of Ulluchu, and many of these families contain more than one genus with similar fruits. Examples include: (Apocynaceae: Ambelania; Caricaceae: Carica; Celastraceae: Maytenus; Chrysobalanaceae: Chrysobalanus, Hirtella, Licania; Convolvulaceae: Dicranostyles; Fabaceae: Aldina, Alexa, Andira, Dipteryx, Dussia, Ormosia; Guttiferae: Tovomita; Hippocrateaceae: Cheiloclinum, Salacia; Icacinaceae: Calatola; Meliaceae: Guarea; Menispermaceae: Abuta, Curarea, Elephantomene, Telitoxicum; Myristicaceae: Virola; Olacaceae: Cathedra; Quiinaceae: Lacunaria; Sabiaceae: Meliosma; Sapindaceae: Cupania, Paullinia; and Sapotaceae: Pouteria. Some of these are still highly important in traditional societies. For example, Ambelania fruit is often consumed; Ormosia contains potent poisonous compounds, but is now mostly used in crafts; Curarea is one of the ingredients of "curare," the famous Amazonian arrow poison; Virola species are still used as potent snuffs in the Amazon, and Paullinia is the source of "yopo," an important stimulant. However, none of these carry the vernacular name Ulluchu.

Fortunately, at this tine the archaeological evidence provides good clues for identification. The Ulluchu fruits found in burials in the 1990's 
are clearly capsules or drupes, slightly commashaped, between 1.5 and $5 \mathrm{~cm}$. long, and slightly grooved. They closely resemble bone, gold, and Spondylus beads found in situ in size, form, and texture. In the iconography, the fruits are often depicted as located on both sides of branches, e.g. on headdresses. It is important to note that this figure has widely extended nostrils, as is often seen in people inhaling hallucinogenic snuffs, and is holding a gourd and pestle. McClelland (2008: Fig. 3.18) interpreted this as lime gourd used for chewing coca. We suggest that this might also be a gourd used to grind the seeds of Ulluchu for inhalation. Further iconographic evidence supports this hypothesis. Runners and messengers associated with Ulluchu are often winged - they literally fly, i.e., the inhalation of Ulluchu gives them wings. The personages have Ulluchu on their belts, Ulluchu seeds floating above their heads, and they hold instruments that closely resemble a typical double snuff tube that would serve to inhale powdered hallucinogenic substances. Thus, it seems possible that one of the uses of Ulluchu may have been as a mind-altering snuff. Another reason for identifying the seeds in the iconography as hallucinogenic Ulluchus is underscored from Moche paintings, e.g a famous Moche scene (McClelland 2008: Fig. 3.34) where monkeys are picking fruits from an Ulluchu tree. It is important to note that the tree depicted has opposite leaves and that seeds are extracted from the fruit, possibly for roasting in a typical oven on the bottom right. The roasted seeds could then be ground to powder and inhaled. The fruits themselves seem to be 5 -valved. The function of Ulluchu as a hallucinogen is reinforced by other imagery (e.g. McClelland 2008: Fig. 3.6), where personages, surrounded by Ulluchu fruits lie on the ground in what clearly appears to be an intoxicated state. In addition, prisoners in sacrificial scenes (e.g. Hocquenghem 2008, Figs. 2.2, 2.3, 2.12 \& 2.24), especially the well known "lines of prisoners" at Huaca El Brujo and Huaca de la Luna all show clearly visible erections (Fig. 12), which may be seen as another indication of the ingestion of some substance causing this effect. From this perspective Larco's term Ulluchu (Larco 1940), if derived from Quechua "ullu-uchu" - "penis pepper," would in fact make sense in describing the possible effects of the plant in question. Also, the association with sexual arousal is reinforced by mythical scenes where an Ulluchu tree grows out of the back of an erotic couple.

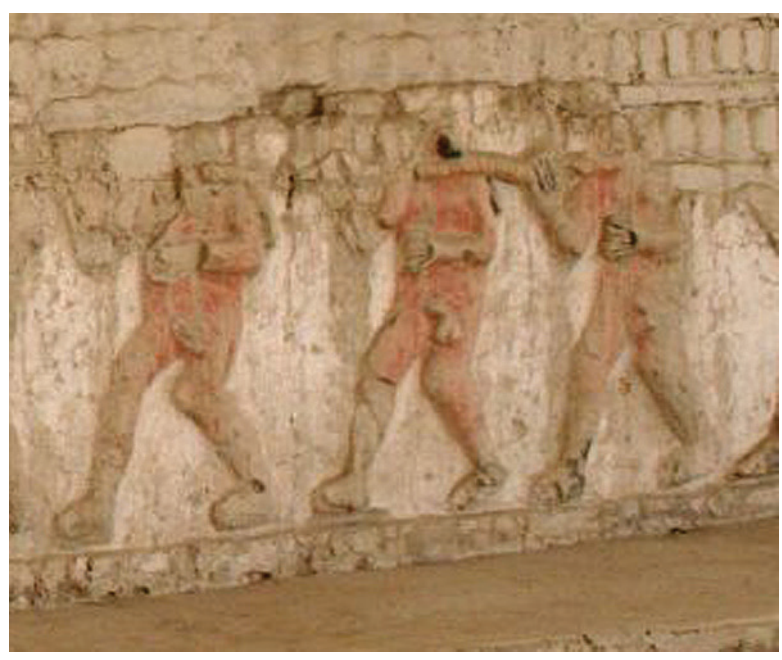

Figure 12. Line of prisoners at Huace El Brujo. Photo: Rainer W. Bussmann

In light of the above, Ulluchu is a tree with opposite leaves and fruits that are drupes between $1-15 \mathrm{~cm}$. long possibly containing active ingredients that would elevate the blood pressure and cause erections, and psycho-active substances. The only plant family from the list above having representatives that meet all these criteria is Meliaceae, and the genus Guarea is the one that most closely fits the description. It includes mostly trees with pinnate leaves (which is unusual for Meliaceae), and fruits that are 3-5 valved capsules, with large, pseudo arillate seeds. The genus Guarea is found throughout Peru, but is mostly restricted to tropical lowland forests, with some species reaching could forest habitat. No species is found along the dry coast of Peru, which indicates that the material must have been widely traded in Moche times. A typical representative is Guarea grandifolia DC. (Fig. 13). The species has clearly pinnate leaves, and the fruits very clearly resemble the archaeological samples. In addition, Guarea contains a large number of species with varying fruit sizes (from 1-15 cm.), calyx swelling, and grooving on the body of the fruit (Fig. 14), which all correlates with the varied Ulluchu imagery in Moche fineline drawings. The seeds of Guarea 
species, with a distinct white navel, very much resemble the seeds depicted in Moche fineline paintings.

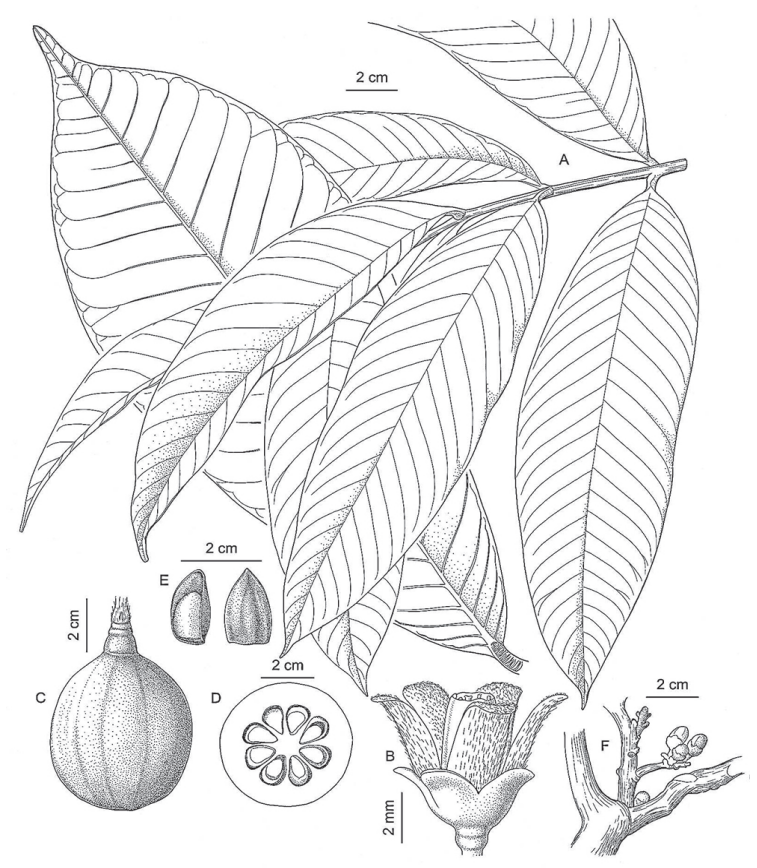

Figure 13. Guarea grandifolia

A. Mature branch; B. Flower; C. Mature fruit; D. Fruit cross section; E. Seeds; F. Branching pattern

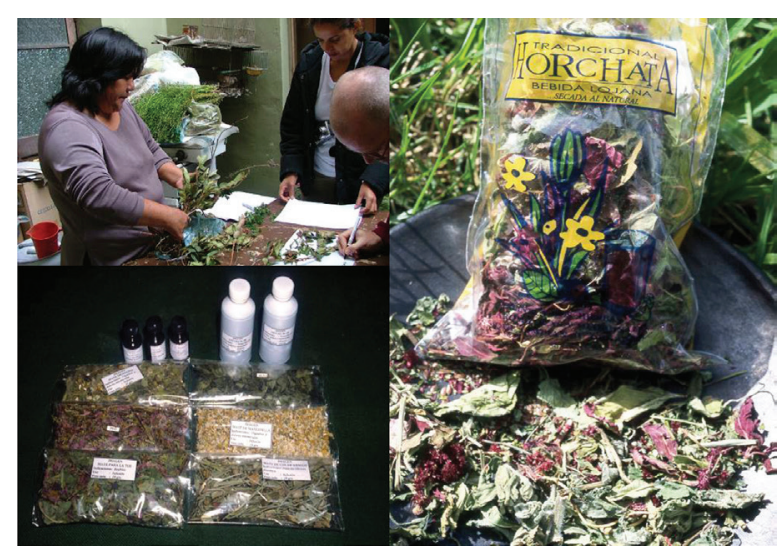

Figure 14. Sustainable plant use - from plant documentation with local healers to production of correctly identified bulk herbal packages and teas for local markets.

Many species of Guarea are known by a wide variety of vernacular names, e.g., Guarea spec.: requia, kushímsakish; G. glabra: yecheñor, yechemor; G. grandifolia: bola requia; G. guidonia: atapio, latapi, latapi caspi, requia colorada, requia latapi, xoro; G. kunthiana: requia, paujil ruro; $G$. purusana: latapi, requia). The wood of many species is used as timber for construction. The wood, bark, and leaves contain compounds that act as abortive, emetic, purgative, and antiamoebiac agents, and the bark is often sold as Coccilliana in expectorant preparations (Kraemer 1915; Rätsch 1998). The fruits and seeds contain a variety of alkaloids that are very rarely used due to their high toxicity (Kraemer 1915). Some of the alkaloids found, e.g. rusbyine, have a structure and effects like emetine, an alkaloid found in Psychotria ipecacuanha (Brot.) Stokes, which has been widely used as an emetic and expectorant. Other species of Psychotria are well known as components in ayahuasca preparations due to their high content of N,N-DMT [30]. In large dosages, ipecac preparations cause high blood pressure, arrhythmia, spasms, and extension of the blood vessels. While the existing literature on Guarea seed compounds is rather fragmentary, it seems clear that a concentrated dosage of Ulluchu seeds, if ingested, would increase a prisoner's heartbeat, elevate the blood pressure, and widen blood vessels thus causing erection. All of this would make it much easier to extract sacrificial blood. Also, when inhaled by priests, the active compounds could have a mindaltering effect, which would not necessarily lead to high levels of toxicity, and could induce very rapid, short-term hallucinations.

We conclude that Ulluchu can be identified as a group of species of the genus Guarea (Meliaceae) based on morphological characteristics. In addition, the chemical composition of the plant's compounds supports the theses that it was used in a sacrificial context to improve the extraction of blood from sacrificial victims. We also suggest that a ground preparation of Guarea seeds, when inhaled, may have been used as a hallucinogen. However, more detailed phytochemical research is needed to corroborate the latter hypothesis.

\section{CHANGING MARKETS}

Exotics played an important role amongst all pants sold in Norhern Peruvian markets. Fifty-nine species $(15 \%)$ found in all markets were exotics. 
However, amongst the species most commonly encountered in the inventories, $40-50 \%$ were exotics. Matricaria recutita (chamomile) was found in the inventory of approximately $70 \%$ of vendors. The next most popular species sold in these markets included Equisetum giganteum, Phyllanthus urinaria, Phyllanthus stipulatus, Phyllanthus niruri (chanca piedra - stone breaker), Eucalyptus globulus (eucalyptus), Piper aduncum, Uncaria tomentosa (cat's claw), Rosmarinus officinalis (rosemary), Peumus boldus, Bixa orellana (achiote) and Buddleja utilis. However, when taking sales volume into account, Croton lechleri (dragon's blood), Uncaria tomentosa, and Eucalyptus globulus were clearly the most important species (Bussmann et al. 2009f).

While it was very easy for all vendors to name their most important and frequently sold species, it proofed impossible to get detailed information about species that vendors observed as "rare" or "disappearing". In most cases, vendors mentioned species as rare because they themselves did not sell them, in many cases these plants were very common outside the market (e.g. Plantago major or common plantain), or because demand was so low, that it would not have made sense to carry them in their inventories.Very small vendors had inventories that represented the most common medicinal plants available, and excluded most species in the large "witchcraft" segment of the pharmacopoeia. On the other hand, wellestablished large stands specialized in supplies for healers (including "magical" plants).

All four markets had inventories containing more than $50 \%$ of all inventoried plant species, but lacked many of the "generalist" plants sold by other vendors. The portfolio of these stands focused almost entirely on "magical" species that are needed to cure illnesses like "susto" (fright), "mal aire" (evil wind), "daño" (damage), "envidia" (envy) and other "magical" or psychosomatic ailments. At the same time, all four vendors catered also to the esoteric tourism crowd that tends to frequent the large markets, and carried a variety of plants that were not used by curanderos, but instead were sold to meet tourist demand.

\section{A look on sustainability - how much plant and for which price?}

More than two thirds of all species sold in Northern Peruvian were claimed to originate from the highlands (sierra), above the timberline, which represents areas often heavily used for agriculture and livestock grazing. The overall value of medicinal plants in these markets reaches a staggering 1.2 million US\$/year. This figure only represents the share of market vendors, and does not include the amount local healers charge for their cure. Thus, medicinal plants contribute significantly to the local economy. Such an immense market raises questions of the sustainability of this trade, especially because the market analysis does not take into account any informal sales.

Most striking was the fact that 7 indigenous and 3 exotic species, i.e. $2.5 \%$ of all species traded, accounted for more than $40 \%$ of the total sales volume (with 30 and $12 \%$ respectively). Moreover, 31 native species accounted for $50 \%$ of all sales, while only 16 introduced plants contributed to more than a quarter of all material sold. This means that little over $11 \%$ of all plants in the market accounted for about three fourths of all sales. About one third of this sales volume includes all exotic species traded. None of these are rare or endangered. However, the rising market demand might lead to increased production of these exotics, which in turn could have negative effects on the local flora (Bussmann et al. 2007b).

A look at the indigenous species traded highlights important conservation threats. Croton lechleri (dragon's blood), and Uncaria tomentosa (cat's claw) are immensely popular at a local level and each contributes to about $7 \%$ to the overall market value. Both species are also widely traded internationally. The latex of Croton is harvested by cutting or debarking the whole tree. Uncaria is mostly traded as bark, and again the whole plant is normally debarked. Croton is a pioneer species, and apart from $C$. lechleri a few other species of the genus have found their way in the market. Sustainable production of this genus seems possible, but the process has to be closely monitored, and the current practice does not appear sustainable because most Croton is wild 
harvested. The cat's claw trade is so immense, that in fact years ago collectors of this primary forest liana started complaining about a lack of resources (Cabieses Molina 2000) and during the years of this study other Uncaria species, or even Acacia species have appeared in the market as "cat's claw" (own observation). As such, the Uncaria trade is clearly not sustainable.

Some of the other "most important" species are either common weeds (e.g. Desmodium molliculum), or have large populations (e.g. Equisetum giganteum). However, a number of species are very vulnerable. Tillandsia cacticola grows in small areas of the coast as epiphyte (Downer 2006). The habitat, coastal dry forest and shrub, is heavily impacted by urbanization and mechanized agriculture, the impact of the latter worsened by the current bio-fuel boom.

Gentianella alborosea, G. bicolor, G. graminea, Geranium ayavacense and Laccopetalum giganteum are all high altitude species with very limited distribution. Their large-scale collection is clearly unsustainable, and in case of Laccopetalum collectors indicate that supply is harder and harder to find. The fate of a number of species with similar habitat requirements raises comparable concern. The only species under cultivation at this point are exotics, and a few common indigenous species.

When looking at the reasons why people chose medicinal plants or pharmaceuticals for greater consumption, it seemed as though the major reasons were fairly obvious. Many people preferred using plants more often because they are natural and safe. Pharmaceutical products have too many synthetic chemicals and foreign substances that can affect the body. Using plants that have been in use for centuries seems to be a safer and healthier alternative. Many people said that pharmaceuticals were used for particular illnesses, but often had side effects that result in negative impacts elsewhere in the body. Respondents agreed however, that pharmaceuticals products were more effective than medicinal plants. Even though they still used plants, they would not completely depend on them, knowing that there a limit to their use. A lot of agreement was registered for use of doctor's prescriptions. Many people have faith in their doctor, and if he recommends using a certain medicine, they will. This faith is based on the confidence people have in science and medicine with a great deal of research available, which has gained the public's trust. Because of this, people feel safer relying on modern medicine. Along with the research, people know that medicine has noticable effects that can be more easily obtained than those from plants. Plant remedies take longer and are more subtle in their effects. These are reasons why pharmaceuticals are used more often. Although the number was minimal, there were respondents who did say that they used the two kinds of medicine in the same amounts. What was interesting was that people said that they used both together. For example, often people said that they would drink a cup of herbal tea while taking pills. Although people felt that each type of medicine has a role, most agreed that pharmaceuticals provide the best route taken for fighting certain sicknesses.

Traditional Medicine is experiencing increasing demand, especially from a Peruvian perspective, as indicated by the fact that the number of herb vendors, in particular in the markets of Trujillo, has increased in recent years. Also, a wide variety of medicinal plants from Northern Peru can be found in the global market. While this trend might help to maintain traditional practices and to give traditional knowledge the respect it deserves, it poses a serious threat, as signs of over-harvesting of important species are becoming increasingly apparent.

Today the most serious threat to this millennial tradition is the destruction of medicinal plant habitats. Urban sprawl and the sugar industry have already greatly altered the coastal plains around Trujillo and Chiclayo. Climatic change and deforestation are threatening the mountain forest systems that are the source of many medicinal species. Most importantly, the high Andean ecosystems and sacred lagoons where many medicinally active species are found are in danger of being destroyed by large-scale mining activities (Zamora Perez 2007). In order to counteract such influences, close work with local healers, in order to document local knowledge, and use of the results to develop sustainably sourced, and scientifically identified plant material for local marketsis being developed (Fig. 14). The knowledge also gets repatriated in bilingual form (Fig. 15). 


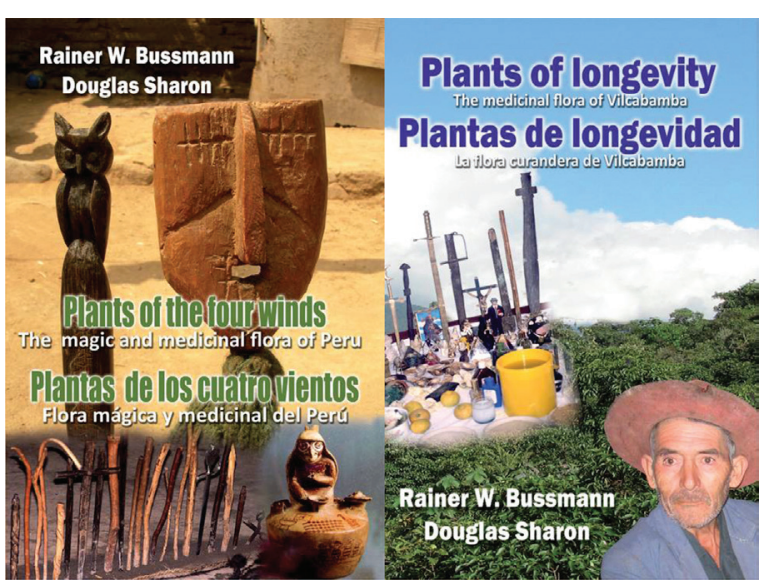

Figure 15. Dissemination of traditional knowledge in bilingual books.

It is apparent that the respondents used medicinal herbs more often than pharmaceutical medicines, but only to a small degree. People generally assumed that plants are healthier and better to use because they are natural and are thought to not have any side-effects. It is difficult to determine if the knowledge of the use of medicinal plants is growing or decreasing, but the indications are that the last generation knows more than the present. However, most of the present generation does teach their children about the use of medicinal plants. The present study also showed what medicinal plants the respondents used for which purposes. It would be interesting to evaluate the properties of the species used in bioassays.Similarly, the plant knowledge of patients at both facilities was largely identical, with an essentially overlapping selection of common, mostly introduced, species, and basically the same number of medicinal plants mentioned overall. This indicates that traditional medicinal knowledge is a major part of a people's culture that is being maintained while patients are also embracing the benefits of western medicine.

This attitude does however lead to profound challenges when it comes to the safety of the plants employed, in particular for applications that require long-term use. Bussmann et al. (2013) found that various species were often sold under the same common names. Some of the different fresh species were readily identifiable botanically, but neither the collectors nor the vendors do made a direct distinction between species (Fig. 16). However, often material was sold in finely powdered form, which makes the morphological identification of the species in the market impossible, and greatly increases the risk for the buyer. The best way to ensure correct identification would be DNA bar-coding. The necessary technical infrastructure is however not available locally. The use of DNA bar-coding as quality control tool to verify species composition of samples on a large scale would require to carefully sample every batch of plant material sold in the market. The volatility of the markets make this is an impossible logistical task. Often the same or closely related species mentioned in literature sell under wide variety of common names. Worse, one species might be sold e.g. as "Hercampuri" in one location or market stand, while selling under a different name at a neighboring stand. As expected there is no consistency in the dosage of plants used, nor do vendors agree on possible side effects.

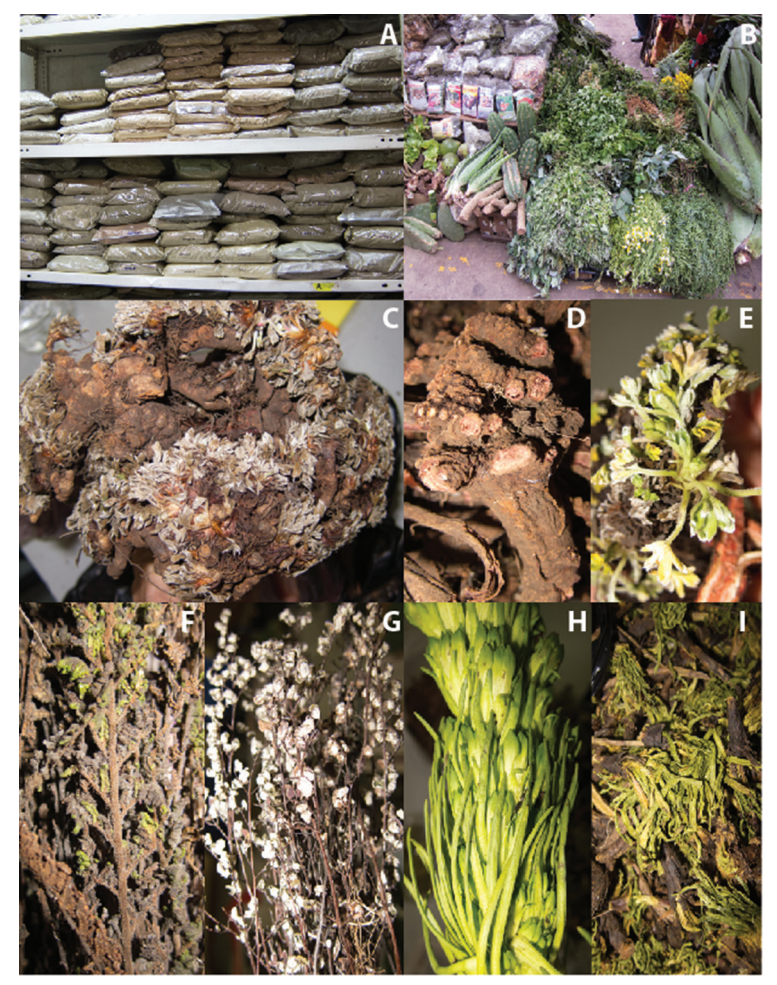

Figure 16. Medicinal plant presentation in Mercado Aviación Lima: A. packaged ground plat material; B. traditional presentation; C-E. Geranium sessiliflorum; D. unidentifiable Geranium fragment; F. Cheilanthes bonariensis; G. Argyrochosma nivea; H. Gentianella thyrsoidea; I. Gentianella nitida. 
Studies indicate that the plant use in Northern Peru, although footing on a millennial tradition, has changed considerably even during the last decades. Even even in case of plant species used for very clearly circumscribed applications, patients run a considerable risk when purchasing their remedies in the local markets, and the possible side effects can be serious. Much more control, and a much more stringent identification of the material sold in public markets, and entering the global supply chain via Internet sales, would be needed.

\section{SACRED SEEDS, THE NAGOYA PROTOCOL AND REPATRIATION OF TRADITIONAL KNOWLEDGE}

Sacred Seeds is one of the programs of the William L. Brown Center at the Missouri Botanical Garden. Creating a global model of sustainable development through botanical research programs, in Sacred Seeds the WLBC works closely with communities in host countries and has long-term success in finding practical solutions to conservation issues (Fig. 17). The program aims to establish in-situ collections of locally important plant species used in traditional medicine, as food, and for other purposes. Participating sanctuaries receive direction, feedback, guidance and advice from the WLBC team, linking experiences in botany, anthropology, traditional healing and conservation with the collective experience of all Sacred Seed sanctuaries. Sacred Seeds strives to facilitate seed storage training, with the possibility of building a relationship with large seed storage facilities, training in plant taxonomy, and publishing assistance and templates for creating educational, scientifically valid literature, and creating a "Sacred Seeds Book" for every garden, in local language, but also for worldwide distribution (Fig. 18). The Sacred Seeds program has currently almost 40 participating foundational gardens, with a network of close to 1500 participating garden units.

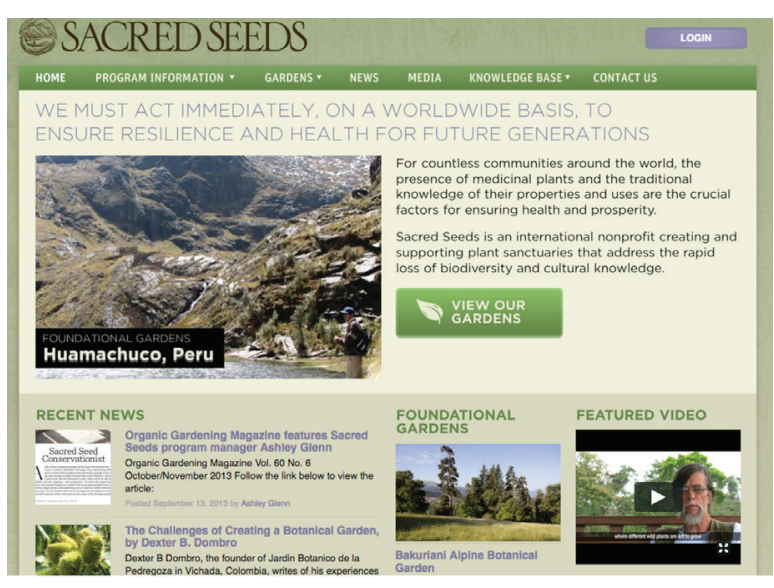

Figure 17. Sacred Seeds Ethnobotanical Garden Network website
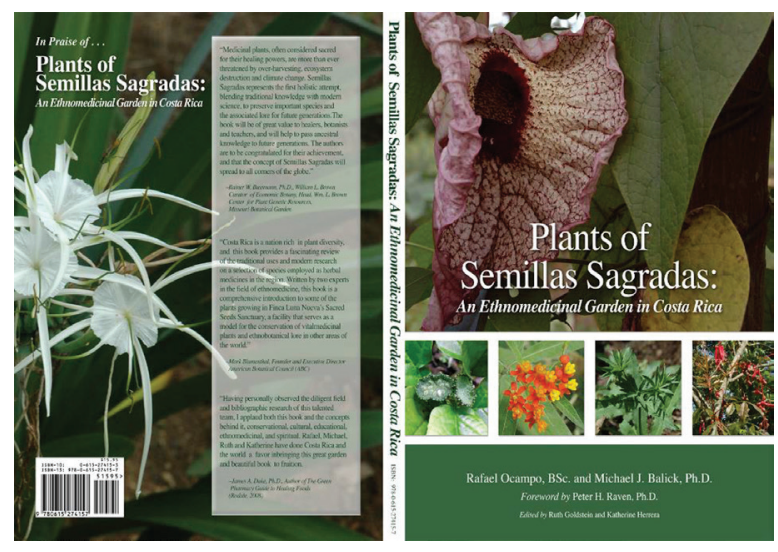

Figure 18. Sacred Seeds - garden guide example

\section{The Nagoya Protocol and repatriation of traditional knowledge}

The final implementation of the "Nagoya Protocol on Access to Genetic Resources and the Fair and Equitable Sharing of Benefits Arising from their Utilization to the Convention on Biological Diversity" last month, has brought a great boost for the rights of indigenous and local communities.

The main objective of the protocol is "the fair and equitable sharing of the benefits arising from the utilization of genetic resources, including by appropriate access to genetic resources and by appropriate transfer of relevant technologies, taking into account all rights over those resources and to technologies, and by appropriate funding, thereby contributing to the conservation of biological diversity and the sustainable use of 
its components," including that "traditional knowledge associated with genetic resources that is held by indigenous and local communities is accessed with the prior and informed consent or approval and involvement of these indigenous and local communities, and that mutually agreed terms have been established."

This is naturally of great importance. The establishment of prior informed consent has, fortunately, been widely practiced already, although there are still projects that place only limited emphasis on permits and consent, because the process is often long and tedious. Under the Nagoya Protocol prior informed consent and providing benefits for knowledge holders is no longer only good ethics, it is also international law. It is to hope that all major granting agencies, whether private or governmental, will soon make proof of prior informed consent a requirement for funding.

The concept, that "benefits" might result from the documentation of traditional knowledge, is somewhat new to many colleagues. In globalized science, where data is easily circulated, it is only just to make sure as much as possible, that the knowledge our counterparts share with us, is not simply appropriated by parties not involved in the original study, whether for scientific or commercial purposes. In practice, this means that the establishment of prior informed consent valid under the Nagoya Protocol, needs to include an explicit statement along the lines that "any work conducted in a community iscarried out under the Nagoya Protocol on Access to Genetic Resources and the Fair and Equitable Sharing of Benefits Arising from their Utilization, and that the right to use and authorship of any traditional knowledge all informants is maintained, as well as that any use of the information obtained, other than for the scientific publication does require additional prior consent of the traditional owners, as well as a consensus on access to benefits resulting from subsequent use."

From our perspective at William L. Brown Center at MBG, the Nagoya Protocol is to be applied with immediate effect, and does not only cover future research, but any previous data gathered by our institution, unless a different agreement with the original owners exists.
Benefit Sharing in this context needs to also not only include the repatriation of the new data gathered, in a language and form accessible to the traditional owners, but also the translation and repatriation of the results of previous studies conducted in the same indigenous or local community, if not already done by the original researchers. In addition, informants, should they so desire, must be allowed full participation as authors in all publications of a study, rather than simply being mentioned as a sideline in the acknowledgments.

Along these lines WLBC has edited a series of books, authored by the members of local communities, that repatriate knowledge on plant use, in local language, and in an appropriate format, as requested by the communities, to the original knowledge holders. These are given to all participating community members, as well as local schools. The first reaction in most communities, when presented with the results of such a collaborative investigation, is astonishment that researchers actually came back, and in fact brought some useful material in local language. This is normally followed by great satisfaction of the participants to be actual authors of the material (Fig. 19). All publications acknowledge the local communities intellectual property under the Nagoya Protocol (Fig. 20), and the authorship of the local collaborators (Fig. 21). In the case of publications on palm use, WLBC developed together with the communities easy to understand symbols for usage categories and plant parts used (Fig. 21). The books include graphic descriptions of plant parts (Fig. 23), with color examples for different growth-, leaf- and fruit-forms (Figs. 24 and 25), followed by in depth description of the individual species (Fig. 26), and detailed, well illustrated desriptions of usage (Fig. 27). In addition to these efforts, WLBC strives to translate previously published studies on traditional knowledge, to make them available in local knowledge, to the benefit of the communities that were involved in the original research. A good example is Bussmann and Paniagua Zambrana (2011). "La etnobotanica de los Chacobo: Traduccion de "Boom, B. - The Ethnobotany of the Chacobo Indians, Beni, Bolivia" (Fig. 28). 

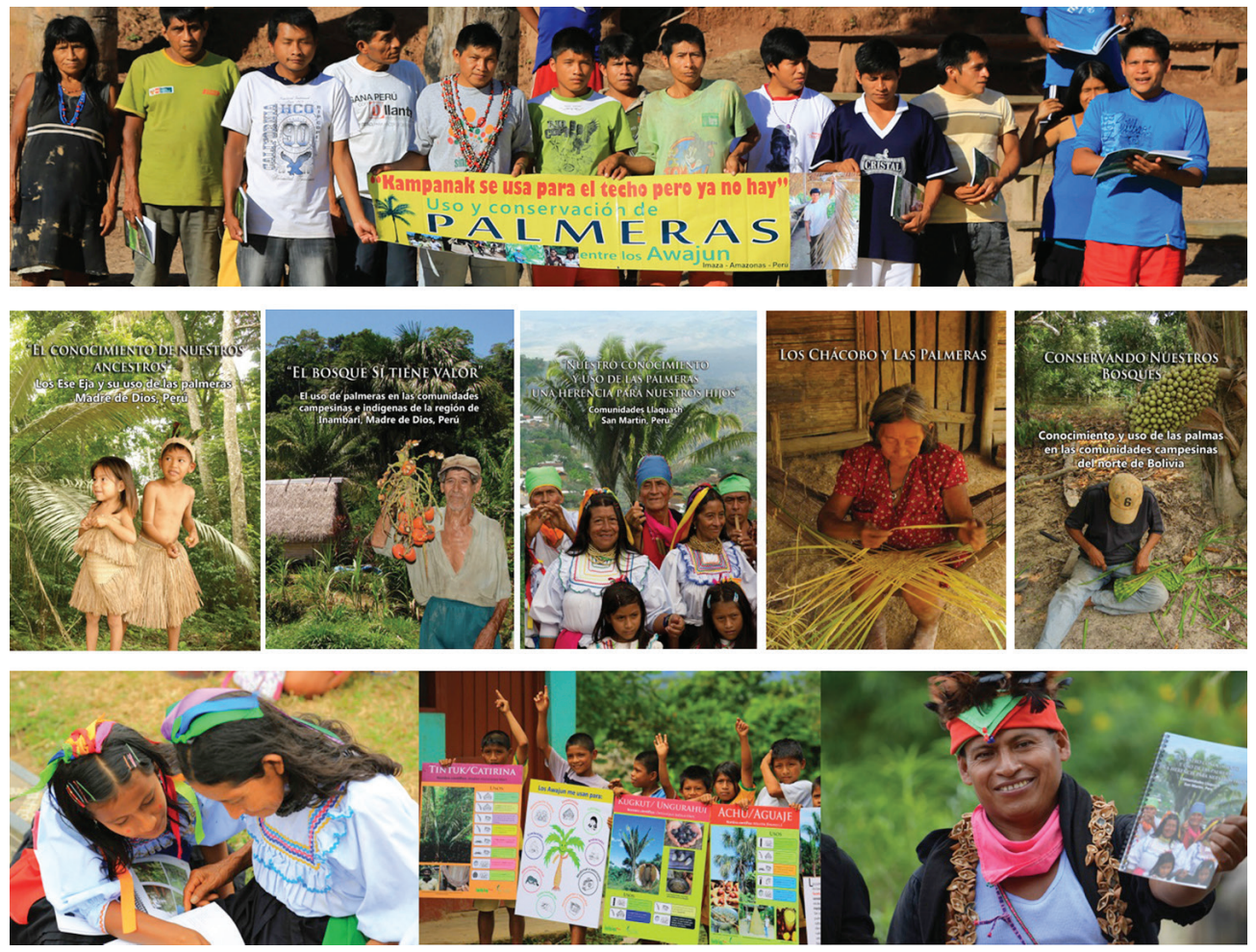

Figure 19. Repatriation of knowledge - Presentation of palm books to local communities

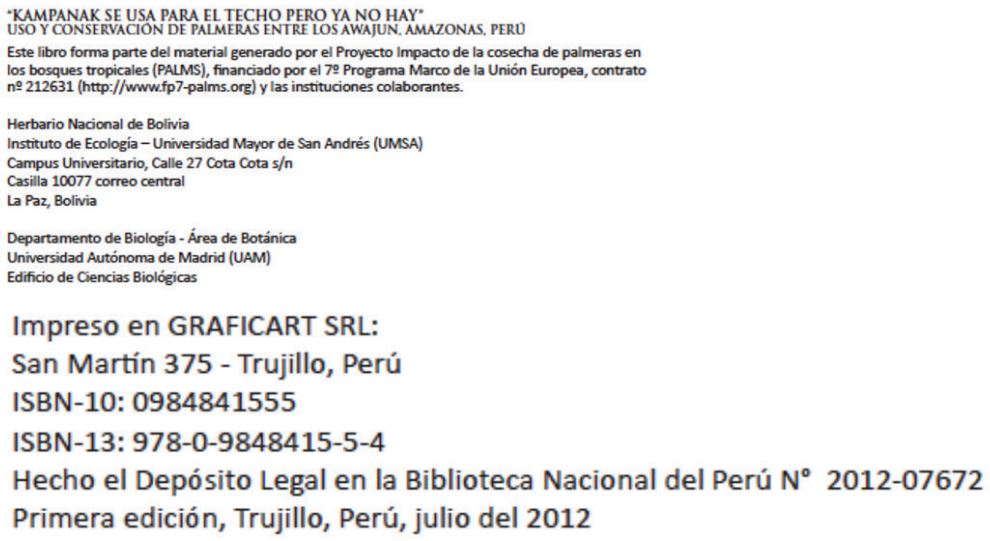

Todos los trabajos se ejecutaron bajo el reglamento del "Protocolo de Nagoya sobre acceso a los recursos genéticos y participación justa y equitativa en los beneficios que se deriven de su utilización al Convenio sobre la Diversidad Biológica" y se mantiene el derecho de autoria de sus conocimientos tradicionales de todos los informantes. Cualquier uso comercial de la información presentada en esta publicación requiere del consenso previo con los informantes y comunidades, y un acuerdo sobre la distribución de beneficios.

IMPRESO EN PERÚ - PRINTED IN PERU

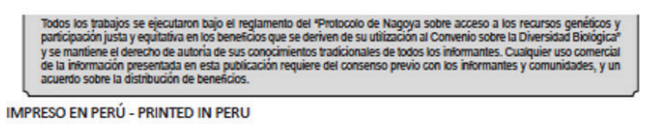

Figure 20. Book page: Acknowledging local intellectual property and the Nagoya Protocol 


\section{AUTORES POR COMUNIDAD}

\section{PALMA REAL}

\begin{tabular}{|c|c|c|}
\hline Adela Shanocua & Florentino Montesinos & María Biaeja \\
\hline Aidé Chetu & German Biaeja & Maria Isabel Saavedra \\
\hline Alejandro Mohahe & German Biaeja & María Naji \\
\hline Alfonsa Sehua & Gloria Sazvedra & Maricruz Shanoco \\
\hline Alfredo Bizeja & Graciela Huohehua & Mateo Biazeja \\
\hline Alicia Saavedra & Gregorio Mejia & Melchor Vauhehua \\
\hline Alina Shoe & Héctor loshi & Mercedes Shanocua \\
\hline Ana Elinei & Henry Posho & Mercedes Shehua \\
\hline Asunta Zapata & Inés Meshi & Midio Huane \\
\hline Benito Huane & Asunta Bizeja & Miguel Domínguez \\
\hline Betti Bizeja & Jesús Meshi & Nina Saavedra \\
\hline Carlitos Tirina & Jesusa Hudomela & Pastora Huaquibeline \\
\hline Carlitos Tirina & Jordán Kioshi & Pilar Valdivia \\
\hline Carmen Machuquia & Jorge Shanoqua & Pio Meshi \\
\hline Cecilio Yoyaje & José Gongors & Raúl Meshi \\
\hline Celestina Hejayha & José Liaqui & Ricardo Yoyaje \\
\hline Zenón Yohahe & Geovana Chaeta & Roger Mahio \\
\hline Clementino Meshi & Juan Shanoqua & Rosa Paketanaji \\
\hline Dali Tipuna & Juanita Ekinei & Rosario Soria \\
\hline Dorilda Posho & Julia Huane & Rosy Viasteno \\
\hline Doris Elinei & Lidia Meshi & Rudi Sehua \\
\hline Elda Hudenda & Lidia Shehua & Ruth Tilihua \\
\hline Elisa Huajohuaho & Lorenzo Shoe & Sara Sazvedra \\
\hline Eliseo Meshi & Lucio Yohahe & Segundo Sazvedra \\
\hline Eliser Biaeja & Luis Biaeja & Teófila Sazvedra \\
\hline Elvira Saavedra & Luzmila Shanokua & Verónica Beshu \\
\hline Esperanza Heyahijiz & Marcela Bizeja & Victoria Meshi \\
\hline Exilda Shanoqua & Marcial Soria & Walter Aycz \\
\hline Felipe Vauhehua & Mardilina Biaeja & Wilma Huahojehua \\
\hline Félix Huali & Margarita Meshi & Yasira Shehua \\
\hline
\end{tabular}

Figure 21. Community authors
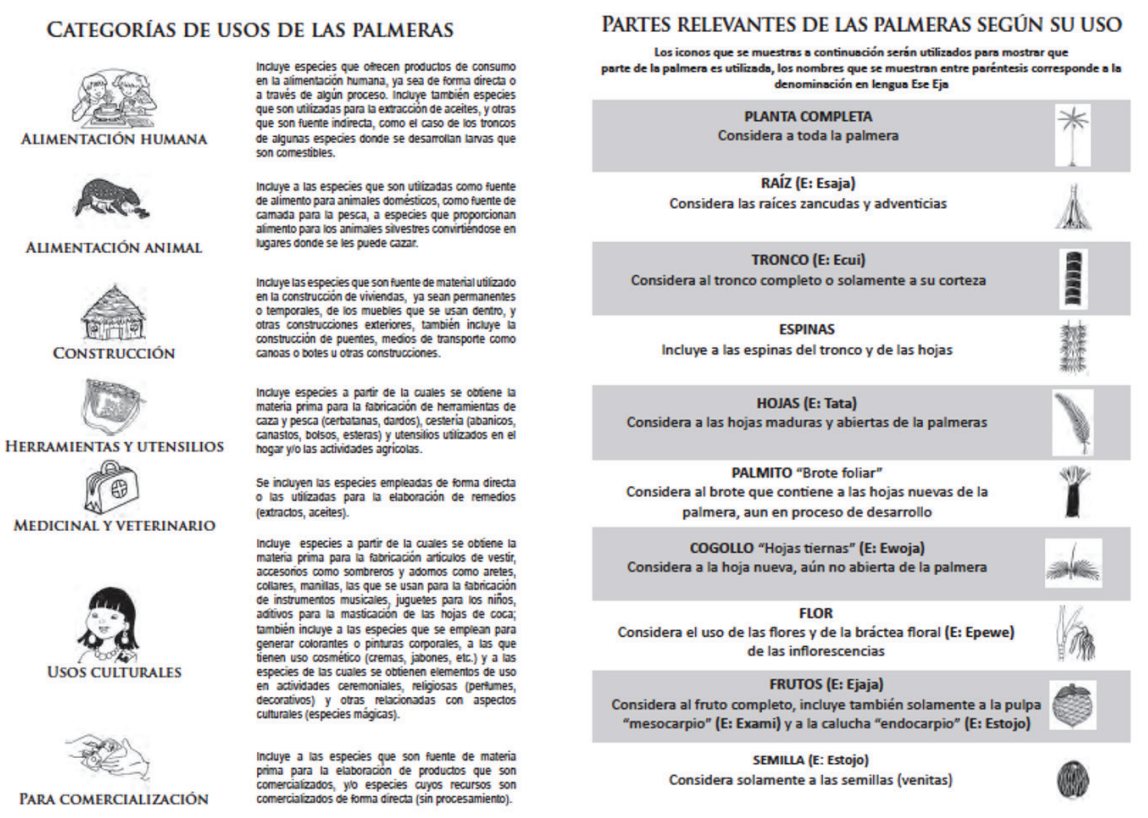

Figure 22. Symbols to explain plant uses and plant parts, developed with local communities 


\title{
CONCEPTOS PREVIOS
}

\section{LA ESTRUCTURA DE LAS PALMERAS}

\begin{abstract}
Para entender la diversidad que existe entre las palmeras que conocen las comunidades indigenas Ese Eja en el Sur de Perú, es necesario familianiz planta y los nombres correspondientes. Para ello presentamos en esta sección una vista rápida de la estructura de las palmeras.
\end{abstract}

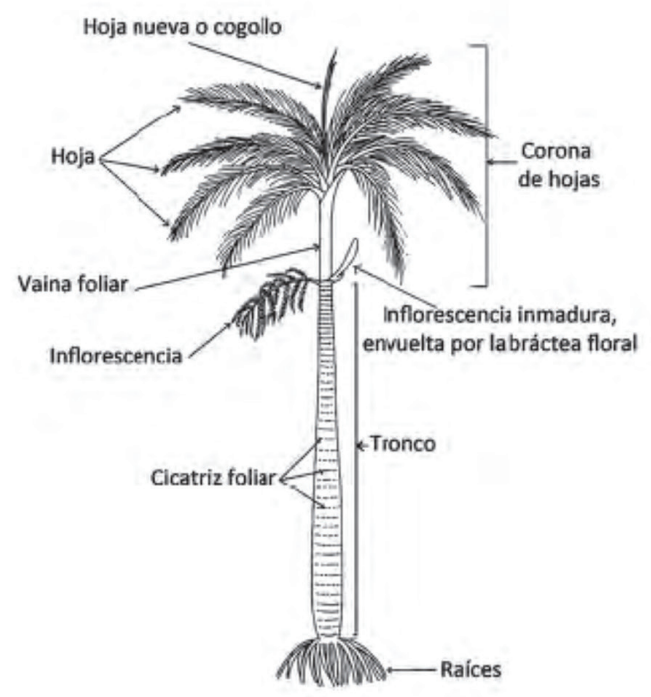

Figure 23. Palm profile - plant parts in local language

TAMAÑO DE LAS PALMERAS

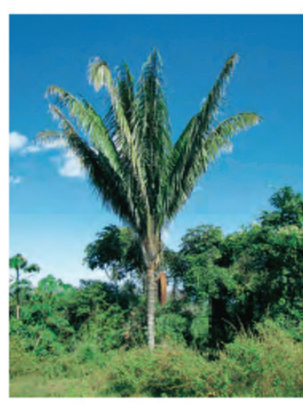

Tronco soütario, aito, grueso
Mojo (Oenocarpus botaua)

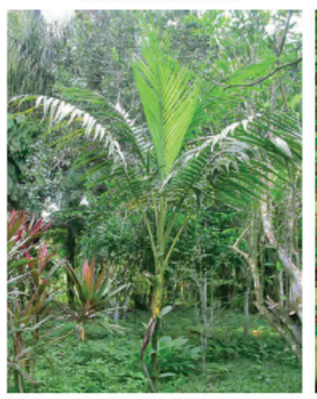

Ironco solitario, bajo, deigado

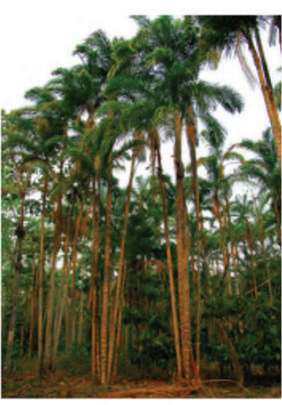

Tronco cespitoso
Mee (Boctris gasipoes)

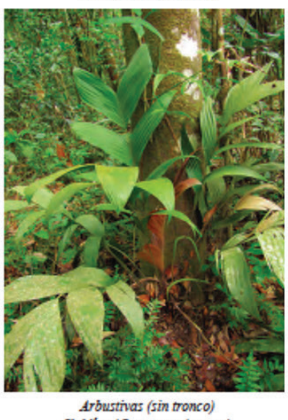

Arbustivas (sin tronco)
Sipi 'Yya (Goonoma deversa)
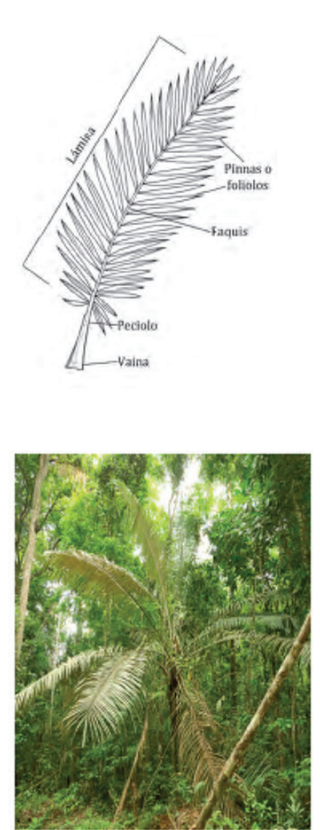

Hojes pinnades
Jajssive (Astrocoryum grotum
LAS HOJAS
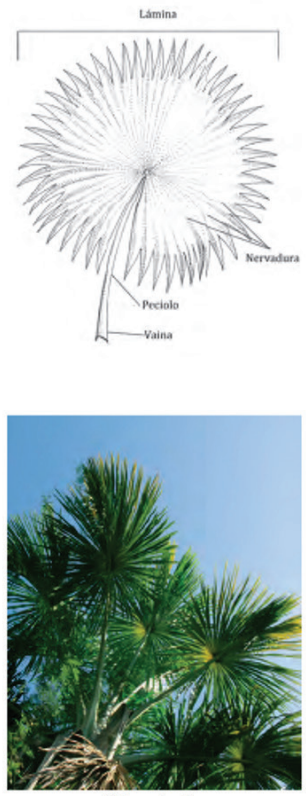

Hojer paimadas
Kohusso (Mountio flexuos

Figure 24. Examples for different palm leaf and growth forms 


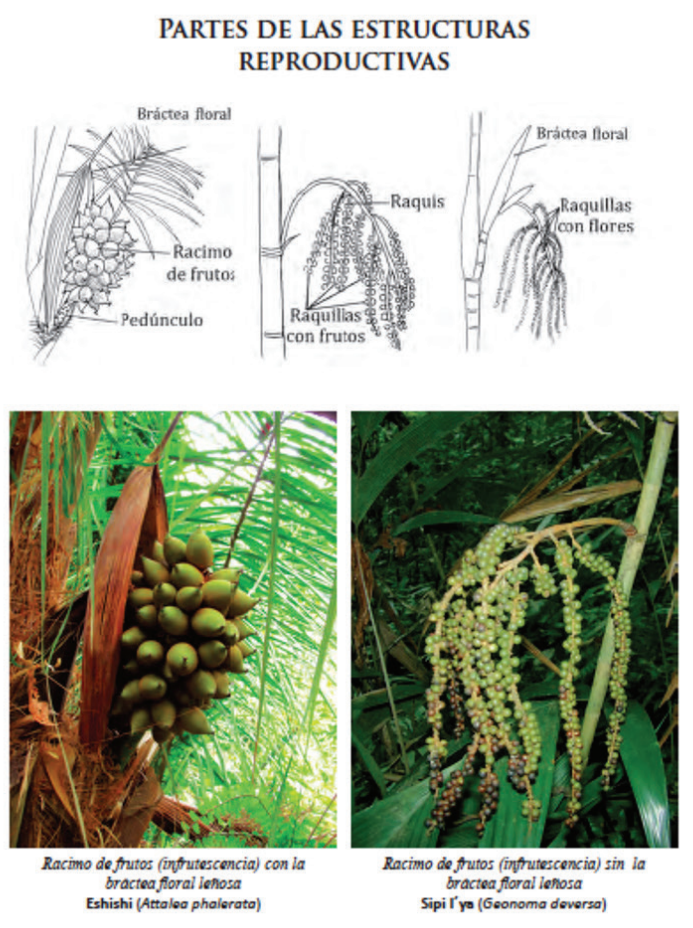

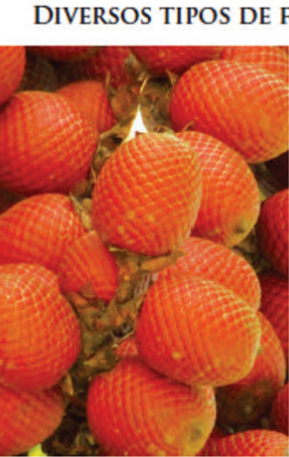

Kohuass (Mauritio flexvoso)
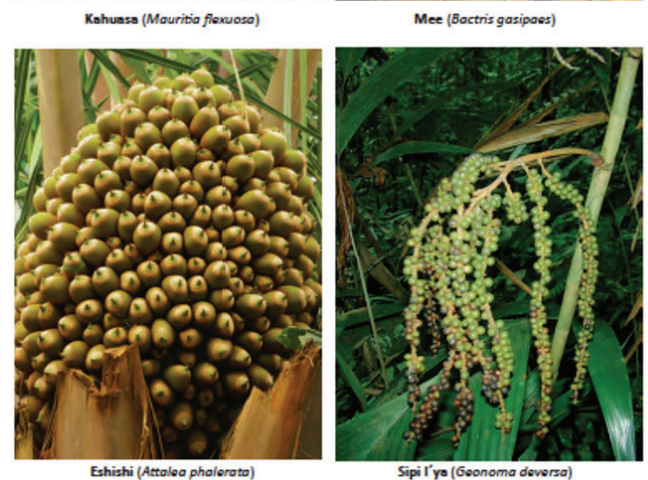

Figure 25. Examples for palm fruits

\section{ESHISHI}
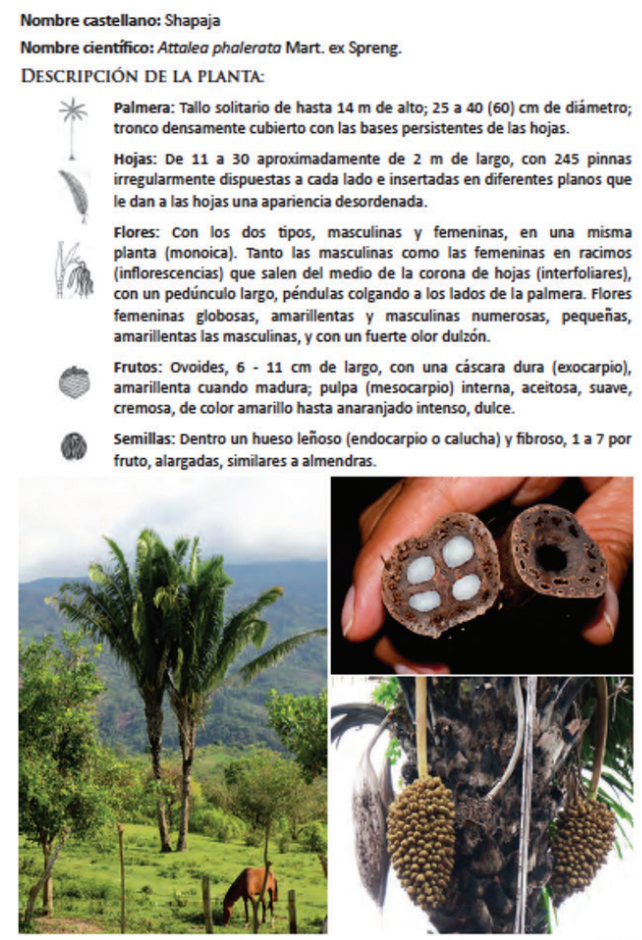

Usos:

En los troncos caidos se desarrollan las larvas de un escarabajo,

En algunos casos se recolecta el suri (E: Sooso), para emplearlo como carnada para la pesca.

Ai Algunas veces recolectan el suri (E: Sooso), y extraen su aceite friéndolos; este aceite filtrado se toma por cucharadas con miel y limón para curar la tos fuerte, neumonía y bronquitis.

Las hojas son unilizadas para la construcción de techos en las casas. Previamente al techado y secado son tratadas de dos formas diferentes. la primera, consiste en partir las hojas por la mitad, al nivel de la nervadura central, las que luego de unen y secan juntas, esta técnica es la de las hojas partidas. La segunda, consiste en realizar un corte superficial a nivel de la nervadura central, lo que permite doblar las pinnas de un lado hacia el otro, de tal forma que quedan en una

Las hojas dobladas ocasionalmente El uso mas frecuente de las hojas es para tejer el surubi o cumba que se colocan en la parte superior de los techos.

Las hojas tiernas o cogollos, se pueden tejer y sirven para confeccionar abanicos (E: Epeii), oventadores, canastos (E: Esaja), esteras (E: Eadiii) y sombreros (E: Ehaoha). Antiguamente también se las usaba para carne y cargas del bosque.

4V Cuando se corta un palma, se aprovecha para sacar el palmito (brote 1 es?

Letor La tola (bráctea floral) es recolectada y utilizada ocasionalmente como

Figure 26. Illustrated plant description 

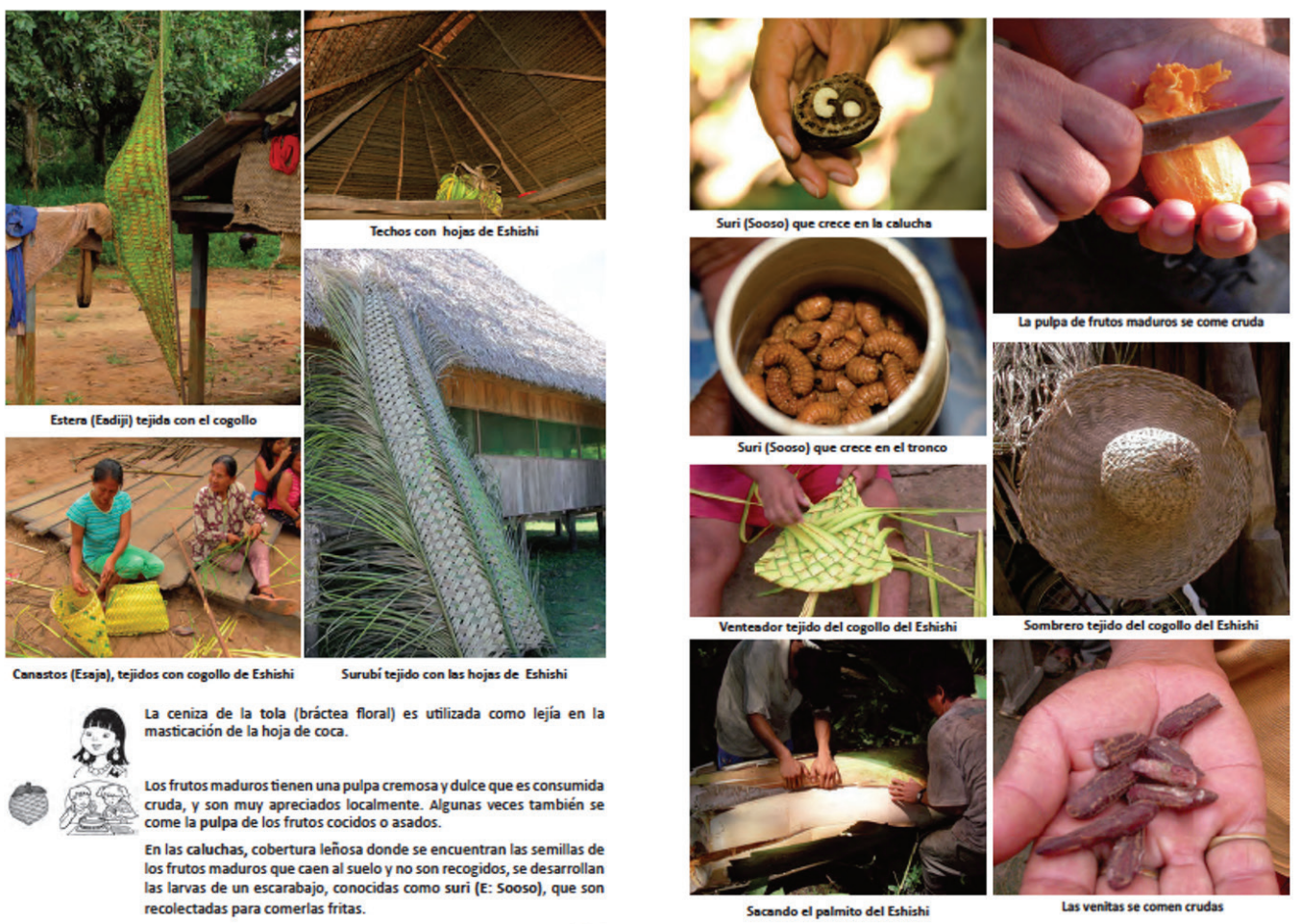
recolectadas para comerlas fritas.

Socondo el polmito del Eshishi

Las venitas se comen crudas

Figure 27. Richly illustrated description of plant use, with local language terms in addition to Spanish

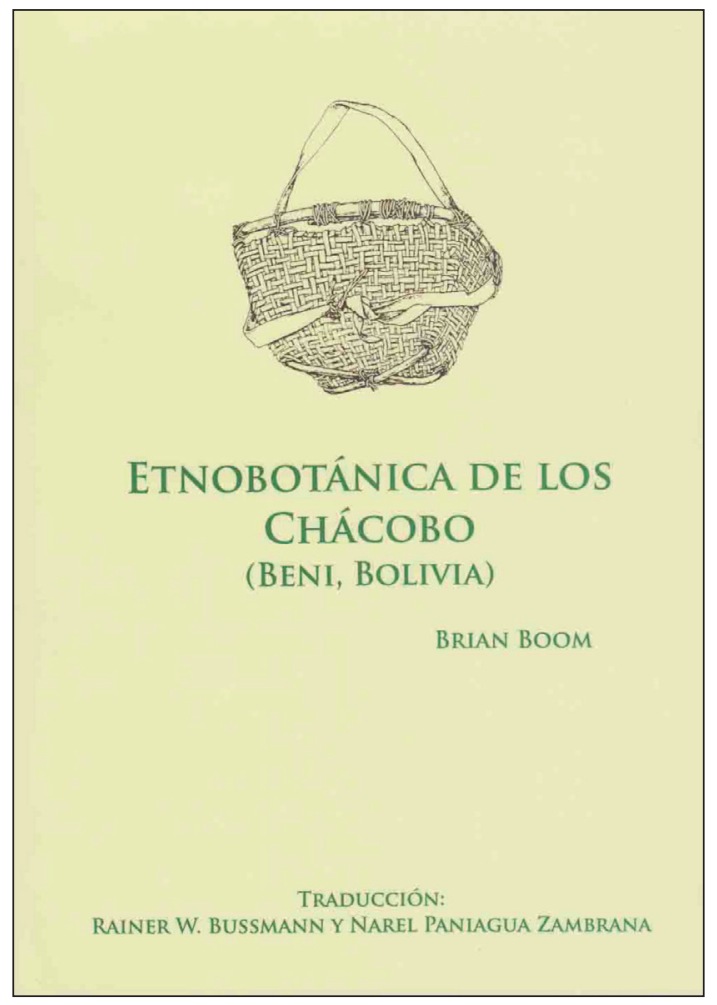

Figure 28. Repatriation of local knowledge in local language: Translation of Boom “Ethnobotany of the Chacobo Indians" 


\section{A Global Program on Conservation of Useful Plants and Traditional Knowledge: A Call to Action}

On 1-2 May 2013 WLBC brought international experts on plants used by humankind together in St Louis Missouri to consider the ways in which a global crisis now underway - the loss of tens of thousands of plant species - can be addressed. These threatened plants include species vital to the lives of people throughout the world, including plants used for food and nutrition, medicine, cultural and spiritual purposes, and the maintenance of livelihoods; they are needed to redress poverty, provide food security, and ensure sustainable development in many nations. Plants and their associated biocultural knowledge play an essential role in the ecosystem services that support all life on Earth (Barve at a. 2013).

The resulting statement is not only an appeal to the international community to address the tragic loss of plant diversity but a call for the development of a concerted effort worldwide to address the loss of essential knowledge about plants and their uses, especially at the level of local communities.

The meeting specifically focused on the objectives of the Global Strategy for Plant Conservation (GSPC), an initiative adopted by the U.N. Convention on Biological Diversity in 2002, and subsequently updated in 2010 , as well as the GSPC targets pertaining to the maintenance and preservation of useful and culturally significant plants. The participants concluded that there is also a great urgency to address the vital importance of traditional knowledge about plants, their utility, management, and conservation. This unique, often ancient, and detailed knowledge is typically held and maintained by local and indigenous communities.

The workshop contributors urged the development of a global program on the conservation of useful plants and associated knowledge, taking into account the need to:

- Call on the international community and governments to recognize the importance of wild and cultivated plant diversity, as well as the associated knowledge of their usefulness as a vital present-day and future resource. This should be accomplished through the successful implementation of the GSPC objectives and targets by 2020 .

- Highlight the need for a concerted international effort to compile a widely accessible global catalogue of useful plants of importance for human kind, while respecting intellectual property rights, local ownership of knowledge and appropriate benefit sharing.

- Assist local peoples in the preservation of their traditional knowledge in a culturally appropriate manner.

- Stress the need for cross cultural and multilevel partnerships in the effort to build on and share experiences on conservation of culturally significant plants, their sustainable use, and associated knowledge.

- Develop an international research platform to address gaps in scientific knowledge of useful plants.

- Facilitate capacity building and training opportunities in ethnobotany, particularly in countries and regions with significant gaps in such resources.

- Support and encourage biocultural knowledge transmission and custodianship.

- Develop the appropriate facilities, methodologies, and techniques to support culturally sensitive curation of biocultural collections (artifacts, herbarium vouchers, produces, living collections, etc.) and associated traditional knowledge.

- Elaborate and disseminate educational materials and resources in appropriate languages that support and promote the study and use of traditional knowledge, and insure their inclusion in educational curricula.

- Develop a toolbox of methodologies, case studies, manuals, and good practices in order to support the conservation of useful plant and associated knowledge.

- Highlight the need for measurable indicators that monitor progress in 
the conservation of useful plants and associated knowledge.

- Follow the framework provided by the Nagoya Protocol on Access to Genetic Resources and the Fair and Equitable Sharing of Benefits Arising from their Utilization (ABS) to the Convention on Biological Diversity and FAO's International Treaty on Plant Genetic Resources for Food and Agriculture, in order to manage and achieve ethical standards for access, fair and equitable benefit sharing, traditional resource and farmers' rights, and the protection of intellectual property.

\section{CONCLUSIONS}

Current research indicates that the composition of the local pharmacopoeia in Northen Peru and Southern Ecuador has changed since colonial times (Martinez Compañon 1789; Ruiz 1777-1788; Bussmann et al. 2009e). However, in Northern Peru the overall number of medicinal plants employed seems to have remained at a comparable level, while plant use in Southern Ecuador has decreased. This indicates that the Northern Peruvian health tradition is still going strong, and that the healers and public are constantly experimenting with new remedies. One example of this is the sudden appearance of Noni (Morinda citrifolia) fruits and products in large quantities in plant pharmacies and markets in the region since 2005. This plant was not available before, but is heavily marketed worldwide. Peruvian sellers are clearly reacting to a global market trend and are trying to introduce this new species to their customers. This indicates that local herbalists and herb merchants are carefully watching international health trends to include promising species in their own repertoire. In Southern Ecuador, healers were not able to experiment with new remedies due to persecution and legal restrictions. As a result, the pharmacopoeia in this region remained on an early colonial level, with loss of significant knowledge.

The use of hallucinogens, in particular the San Pedro cactus (Echinopsis pachanoi) is still a vital component of Andean healing practices, and has been around for millennia. San Pedro can often be found in Cupisnique and Moche iconography. Five hundred years of suppression of traditional healing practices by Western medicine have not managed to destroy this tradition in Peru. The use of San Pedro, together with additives like Angel's Trumpet (Brugmansia spp.), Jimsonweed (Datura ferox), and tobacco, is still a central part of curing ceremonies in Northern Peru. Healers are in fact experimenting with new hallucinogens, and some northern curanderos have started to include decoctions of Ayahuasca (Banisteriopsis caapi) in their rituals.

Although not formally acknowledged, Southern Ecuador falls into the Northern Peruvian cultural area. It appears to represent a region where traditional plant knowledge, though important, has declined considerably. Southern Ecuadorian curanderos and parteras (midwives) having almost entirely abandoned indigenous rituals. In fact, San Pedro usage was not mentioned as a mind-altering plant by any healer or midwife interviewed, and was not used in curing ceremonies. Centuries of prohibition have led to a pronounced abandonment of traditional knowledge. This is also reflected in the current study. Many plants used for "magical" purposes in Peru have disappeared from traditional use in Ecuador. The fear of prosecution is still very deeply rooted in the healer community, and most healers interviewed stated that they did not wish to be cited by name. Most healing altars or mesas in Southern Ecuador are almost entirely devoid of any "pagan" objects such as seashells, pre-Columbian ceramics, etc. Patients are cleansed, by spraying them with holy water and perfumes. In rare cases tobacco juice and extracts of Jimson weed (Datura ferox) are used to purify the patients. Southern Ecuadorian mesas are also much less elaborate than the mesas of Peruvian curanderos. The incantations used by healers during their curing sessions center on Christian symbolism. References to Andean cosmology are almost entirely absent, and the use of guinea pigs as diagnostic instruments has all but disappeared from the tool kit of these healers.

Interestingly, Peruvian curanderos have started to fill this spiritual void in Southern Ecuador. Healers from the Northern Peruvian mountains and coastal plains frequently cross over to Ecuador to offer their services to patients -- including 
increasing numbers of foreigners with a "New Age" orientation -- who are not satisfied with the more Westernized approach of Ecuadorian healers. These Peruvian colleagues have much more elaborate plant knowledge, and their mesas as well as their incantations follow a more traditional pattern.

\section{CONFLICT OF INTEREST}

The authors declare that they have no conflict of interest.

\section{REFERENCES}

1. Acosta J de (1590) Historia natural y moral de las Indias. Sevilla.

2. Agurto $\mathrm{J}(2005)$ ¿Como prevenir la biopirateria en el Peru? Reflexiones y Propuestas pp. 70-73. Lerma Gomez E.I.R.L., LimaMiraflores.

3. Alcedo A de (1786-89) Diccionario geografico histórico de las indias occidentales o América. Madrid.

4. Alva W (1994) Sipán: descubrimiento y investigación. Cultura y artes del antiguo Perú. Backus \& Johnston, Lima.

5. Alva W, Donnan CB (1993) Royal Tombs of Sipán. Fowler Museum of Cultural History, University of California, Los Angeles.

6. Alva W, Donnan CB (1994) Tales from a Peruvian Crypt. Natural History 103(5):26-36.

7. Angulo $P(2009)$ Nuevos enfoques en la investigación de plantas medicinales. In Garrafa R (ed) Medicina Tradicional Andina, Planteamientos y aproximaciones. CBC/CMA, Cuzco, pp. 351384.

8. Baker J, Borris R, Carté B, Cordell G, Soejarto D, Cragg G, Gupta M, Iwo M, Madulid D, Tyler V (1995) Natural Product Discovery and Development, New Perspectives on International Collaboration. Journal of Natural Products 58(9):1325-1357.

9. Bannister K, Barrett $\mathrm{K}$ (2001) Challenging the status quo in ethnobotany, A new paradigm for publication may protect cultural knowledge and traditional resources. Cultural Survival Quarterly 10-12.

10. Barve V, Bhatti R, Bussmann RW, Bye R, Chen J, Dulloo E, Giovannini P, Linares E, Magill R, Roguet D, Salick J, On TV, Vandebroek I, Wightman G, Wyse Jackson P (2013) A Global Program on Conservation of Useful Plants and Traditional Knowledge - A Call to Action. https://www.researchgate.net/ publication/236633499_A_Global_Program_on_Conservation_ of_Useful_Plants_and_Traditional_Knowledge_A_Call_to_ Action?ev=prf_pub

11. Béjar E, Bussmann RW, Roa C, Sharon D (1997) Pharmacological search for active ingredients in medicinal plants of Latin America. In: Shuman T, Garrett M, Wozniak L (eds), International Symposium on Herbal Medicine, A Holistic Approach. SDSU International Institute for Human Resources Development, San Diego, pp. 63-81.
12. Béjar E, Bussmann RW, Roa C, Sharon D (2001) Herbs of Southern Ecuador - Hierbas del Sur Ecuatoriano. Latin Herbal Press, San Diego.

13. Brack Egg A (1999) Diccionario enciclopédico de plantas útiles del Perú. PNUD - CBC, Cuscso.

14. Brack Egg A (2004) Biodiversidad, pobreza y bionegocios. Lima.

15. Brako L, Zarucchi JL (eds) (1993) Catalogue of the Flowering Plants and Gymnosperms of Peru. Missouri Botanical Garden, Saint Louis, MO.

16. Breevort P (1998) The Booming U. S. Botanical Market, A New Overview. HerbalGram 44

17. Brown M (2003) Who owns native culture? Harvard University Press, Cambridge.

18. Brüning HH (2004) Diccionario Mochica. Universidad de San Martin de Porres, Lima.

19. Buitron X (1999) Ecuador, uso y comercio de plantasmedicinales, situacion actual y aspectosimportantesparasuconservación. TRAFFIC International, Cambridge, UK.

20. Bussmann RW (2006) Manteniendo el balance de naturaleza y hombre, La diversidad florística andina y su importancia por la diversidad cultural - ejemplos del Norte de.Perú y Sur de Ecuador. Arnaldoa 13(2):382-397.

21. Bussmann RW, Glenn A, Meyer $K$, Townesmith A, Rothrock $A$, Sharon D, Castro M, Cardenas R, Regalado S, Toro R, Chait G, Malca G, Perez F (2009a) Antibacterial Activity of Medicinal Plants of Northern Peru-Part II. Arnaldoa 16(1):93-103.

22. Bussmann RW, Glenn A, Meyer K, Rothrock A, Townesmith $A$, Sharon D, Castro M, Cardenas R, Regalado S, Toro R, Chait G, Malca G, Perez F (2009b) Phyto-Chemical Analysis of Peruvian Medicinal Plants. Arnaldoa 16(1):105-110.

23. Bussmann RW, Glenn A, Meyer K, Kuhlman A, Townesmith A (2010a) Herbal mixtures in traditional medicine in Northern Peru. Journal of Ethnobiology and Ethnomedicine 6(10).

24. Bussmann RW, Malca G, Glenn A, Sharon D, Chait G, Diaz D, Pourmand K, Jonat B, Somogny S, Guardado G, Aguirre C, Chan R, Meyer K, Kuhlman A, Townesmith A, Effio J, Frias F, Benito M (2010b) Minimum inhibitory concentrations of medicinal plants used in Northern Peru as antibacterial remedies. Journal of Ethnopharmacology 132:101-108.

25. Bussmann RW, Glenn A (2010c) Cooling the Heat - Traditional remedies for malaria and fever in Northern Peru. Ethobotany Research and Applications (8):125-134.

26. Bussmann RW, Glenn A, Sharon D, Chait G, Diaz D, Pourmand K, Jonat S, Somogy S, Guardado G, Aguirre C, Chan R, Meyer A, Townesmith A (2010d) Proving that Traditional Knowledge Works, The antibacterial activity of Northern Peruvian medicinal plants. Ethnobotany Research and Applications 9:67-96.

27. Bussmann RW, Malca G, Glenn A, Sharon D, Nilsen $B$, Parris B, Dubose D, Ruiz D, Saleda J, Martinez M, Carillo L, Kuhlman A, Townesmith A (2011) Toxicity of medicinal plants used in traditional medicine in Northern Peru. Journal of Ethnopharmacology 137:121-140.

28. Bussmann RW, Paniagua Zambrana N, Rivas Chamorro M, Molina Moreira N, Cuadros Negri ML, Olivera J (2013) Peril in the market - classification and dosage of species used as anti-diabetics in Lima, Peru. Journal of Ethnobiology and Ethnomedicine 9(37).

29. Bussmann RW, Sharon D (2006a) Traditional plant use in Southern Ecuador. Journal of Ethnobiology and Ethnomedicine 2(44). 
30. Bussmann RW, Sharon D (2006b) Traditional plant use in Northern Peru, Tracking two thousand years of health culture. Journal of Ethnobiology and Ethnomedicine 2(47).

31. Bussmann RW, Sharon D (2007a) Plants of the four winds - The magic and medicinal flora of Peru. Plantas de los cuatro vientos - La flora mágica y medicinal del Perú. Graficart, Trujillo.

32. Bussmann RW, Sharon D (2007b) Plants of Iongevity - The medicinal flora of Vilcabamba. Plantas de la longevidad - La flora medicinal de Vilcabamba. Graficart, Trujillo.

33. Bussmann RW, Sharon D (2009d) Naming a phantom-the quest to find the identity of Ulluchu, an unidentified ceremonial plant of the Moche culture in Northern Peru. Journal of Ethnobiology and Ethnomedicine 5(8).

34. Bussmann RW, Sharon D (2009e) Shadows of the colonial pastdiverging plant use in Northern Peru and Southern Ecuador. Journal of Ethnobiology and Ethnomedicine 5(4).

35. Bussmann RW, Sharon D (2009f) From collection to market and cure-Traditional medicinal use in Northern Peru. In: Albuquerque $\mathrm{U}$ (ed) Recent Development and Case Studies in Ethnobotany. Recife, pp.184-207.

36. Bussmann RW, Sharon D, Diaz D, Barocio Y (2008a) Peruvian plants canchalagua (Schkuhria pinnata (Lam.) Kuntze), hercampuri (Gentianella alborosea (Gilg.) Fabris), and corpus way (Gentianella bicolor (Wedd.) J. Pringle) prove to be effective in the treatment of acné. Arnaldoa 15(1):149-152.

37. Bussmann RW, Sharon D, Garcia M (2009a) From Chamomile to Aspirin? Medicinal Plant use among clients at Laboratorios Beal in Trujillo, Peru. Ethnobotany Research and Applications 7:399407.

38. Bussmann RW, Sharon D, Lopez A (2007c) Blending Traditional and Western Medicine, Medicinal plant use among patients at Clinic Anticona in El Porvenir, Peru. Ethnobotany Research and Applications 5:185-199.

39. Bussmann RW, Sharon D, Perez F, Díaz D, Ford T, Rasheed T, Silva R (2008b) Antibacterial activity of Northern-Peruvian Medicinal Plants - a low cost laboratory.approach to assess biological activity. Arnaldoa 15(1):127-148.

40. Bussmann RW, Sharon D, Vandebroek I, Jones AA, Revene Z (2007b) Health for sale, the medicinal plant markets in Trujillo and Chiclayo, Northern Peru. Journal of Ethnobiology and Ethnomedicine 3(37)

41. Cabieses Molina $F(2000)$ La Uña de Gato u su entorno. De la Selva a la farmacia. Universidad de San Martin De Porres, Lima.

42. Camino $L$ (1992/1999) Cerros, plantas y lagunas ponderosas - la medicina al norte del Perú. Lluvia Editores, Lima.

43. Cano JH, Volpato $\mathrm{G}$ (2004) Herbal mixtures in the traditional medicine of Eastern Cuba. Journal of Ethnopharmacology 90:293316.

44. Carrillo L (2012) Scientific Validation? How Bioprospecting Laboratory Practices Contribute to the Devaluation of Traditional Medicinal Knowledge. The Berkeley McNair Research Journal, vol. 19, Spring.

45. Cobo B (1653) Historia del Nuevo Mundo, 2 tomos. Sevilla.

46. Cobo B (1956) In: Mateos F de (ed), Historia del Nuevo Mundo. Ediciones Atlas, Madrid.

47. Connally MPE, Fabiano E, Patel IH, Kinyanjui SM, Mberu EK, Watkins WM (1996) Antimalarial activity in crude extracts of Malawian medicinal plants. Annals of Tropical Medicine and Parasitology 90:597-602.
48. Cox P, Balick M (1994) The Ethnobotanical Approach to Drug Discovery. Scientific American 270(6):82-87.

49. D'Agostino M, De Simone F, Tommasi N, Pizza C (1995a) Constituents of Culcitium canescens. Fitoterapia 66:550-551.

50. D'Agostino M, Pizza C, De Simone F (1995b) Flavone and flavonol glycosides from Desmodium mollicum. Fitoterapia 66:384-385.

51. Domenighetti G, Grilli R, Gutzwiller F, Quaglia J (2000) Usage personnel de pratiques relevant des médecines douce sou alternatives parmi les médecins suisses. Médecine \& Hygiène 58: 22-91.

52. Donnan CB, Castillo LJ (1994) Excavaciones de tumbas de sacerdotes Moche en San José de Moro, Jequetepeque. In: Uceda S, Mujica E (eds) Moche: Propuestas y Perspectivas, 5. Travaux de I'Institut Français d'Etudes Andines 79:415-442.

53. Downer CC (2006) Insights, Mining Peru's Andean Forest Puts Unique Species, Ecosystem at Risk. Environmental News Service, Feb 6.

54. Eisenberg DM, Davis RB, Ettner SL, Appel S, Wilkey S, Rompay M van, Kessler RC (1998) Trends in alternative medicine use in the United States, 1990-1997, results of a follow-up national survey. Journal of the American Medical Association 280(18):1569-1575.

55. El Kamali H, El Kijalifa KE (1997) Treatment of malaria through herbal drug in the central Sudan. Fitoterapia 6:527-528.

56. Elisabetsky E, Castilhos C (1990) Plants used as analgesics by Amazonian caboclos as a basis for selecting plants for investigation. International Journal of Crude Drug Research 28:309-320.

57. EsSalud/Organización Panamericana de Salud (2000) Estudio Costo-Efectividad, Programa Nacional de Medicina Complementaria. Seguro Social de EsSalud (Study of Cost Effectiveness, National Program in Complementary Medicine. Social Security of EsSalud). Lima, EsSalud/Organización Panamericana de Salud.

58. Fernández M (2005) La OMS y los sistemas médicos tradicionales. In Garrafa R, Garrafa R (eds) Medicina Tradicional, Planteamientos y aproximaciones. CBC/CMA, Cuzco.

59. Ferro M, Ruiz $P$ (eds) (2005) ¿Cómo prevenir la Biopiratería en el Perú? Reflexiones y Propuestas. Lerma Gómez E.I.R.L., Lima.

60. Ferro M, Ruiz P (eds) (2005) Apuntes sobre Agrobiodiversidad, Conservación, Biotecnología y Conocimientos Tradicionales. Lerma Gómez E.I.R.L., Lima.

61. Fisher P, Ward A (1971) Medicine in Europe, complementary medicine in Europe. British Medical Journal 309:107-111.

62. Gbile ZO (1984) Vernacular Names of Nigerian Plants (Yoruba). FRIN, Ibadan.

63. Gillett NA, Chan C (2000) Applications of immunohistochemistry in the evaluation of immunosuppressive agents. Human \& Experimental Toxicology 19(4):251-254.

64. Girault L (1987) Kallawaya, Curanderos itinerantes de los Andes. UNICEF-OPS-OMS, La Paz.

65. Glass-Coffin B, Sharon D, Uceda S (2004) Curanderos a la sombra de la Huaca de la luna. Bulletin Instute francais d'Etudes Andines 33(1):81-95.

66. Global Industry Analysts Inc (2012) Herbal Supplements and Remedies, A Global Strategic Business Report. Global Industry Analysts, San Jose.

67. Greaves T (1995) Cultural Rights and Ethnography. General Anthropology 1(1): 3-6. 
68. Hay SI, Were EC, Renshaw M, Noor AM, Ochola SA, Olusanmi I, Alipui N, Snow RW (2003) Forecasting, warning, and detection of malaria epidemics, a case study. Lancet 361(9370):1705-1706.

69. Hayden C (2003) When Nature Goes Public, The Making and Unmaking of Bioprospecting in Mexico. Princeton University Press, Princeton and Oxford.

70. Health Canada (2001) Perspectives on Complementary and Alternative Health Care. A Collection of Papers Prepared for Health Canada. Ottawa, Health Canada.

71. Hocquenghem AM (2008) Sacrifices and Ceremonial Calendars in Societies of the Central Andes: A Reconsideration. In: Bourget S, Jones KL (eds): The Art and Archaeology o fthe Moche. University of Texas Press, Austin, pp. 23-42.

72. Hultin E, Wassén H, Bondeson W (1987) Papain in Moche Blood ceremonies. Journal of Ethnopharmacology 19(2):227-228.

73. Iwu M (1996) Implementing the Biodiversity Treaty, how to make international cooperative agreements work. Trends in Biotechnology 3-4(146):67-107.

74. Joralemon D, Sharon D (1993) Sorcery and Shamanism, Curanderos and Clients in Northern Peru. University of Utah Press, Salt Lake City.

75. Kraemer H (1915) Scientific and Applied Pharmacognosy. Philadelphia.

76. Larco Hoyle R (1938) Los mochicas I. Casa editora “La Crónica" y “Variedades", S. A. Ltda. Lima.

77. Larco Hoyle R (1939) Los Mochicas II. Casa editora "La Crónica" y "Variedades", S. A. Ltda. Lima.

78. Marínez Compañon DB (1789) Razón de las especies de la naturaleza y del arte del obispado de Trujillo del Perú. Tomos III-V, Sevilla.

79. McClelland D (1977) The Ulluchu: A Moche Symbolic Fruit. In: Cordy-Collins A, Stern J (eds) Pre-Columbian Art History. Peek Publications, Palo Alto, pp. 435-452.

80. McClelland D (2008) Ulluchu - An elusive fruit. In: Bourget S, Jones KL (eds) The Art and Archaeology of the Moche. University of Texas Press, Austin, pp. 43-65.

81. Milliken W (1997) Traditional anti-malarial medicine in Roraim, Brazil. Economic Botany 51(3):212-237.

82. Minakawa N, Sonye G, Mogi M, Githeko A, Yan GY (2002) The effects of climatic factors on the distribution and abundance of malaria vectors in Kenya. Journal of Medical Entomology 39(6):833-841.

83. Monardes N (1574) Primera y segunda y tercera partes de la história medicinal de las cosasque se traen de nuestras Indias Occidentales, que sirven en medicina; Tratado de la piedra bezaar, y de la yerva escuerçonera; Diálogo de las grandezas del hierro, y de sus virtudes medicinales; Tratado de la nieve, y del beuer frio. Alonso Escrivano, Seville.

84. Mooney P (1993) Aprovechando la Diversidad, Una Nota Sobre la Diversidad Biológica y el Conocimiento Indígena. América Indígena 3:41-55.

85. Moran K, King SR, Carlson T (2001) Biodiversity prospecting, lessons and prospects. Annual Review of Anthropology 30:505526.

86. Oblitas E (1992) Plantas medicinales de Bolivia. Editorial Los Amigos del Libro, La Paz.

87. Okuyama E, Umeyama K, Ohmori S, Yamazaki M, Satake M (1994) Pharmacologically active components from a Peruvian medicinal plant, Huira-Huira (Culcitium canescens H. \& B.) Chemical and Pharmaceutical Bulletin 42:2183-2186.

88. Perez F, Rodríguez F, León G, Sharon D, Bussmann RW, Willsky G, Guerrero G, Willner K, Castro I (2012) Estudio fitoquímico y antibacteriana de mezclas de plantas medicinales. En búsqueda de nuevos componentes. Pueblo continente 23(2):339-343.

89. Perumal Samy R, Ignacimuthu S (2000) Antibacterial activity of some medicinal plants used by tribals in Western Ghats, India. Journal of Ethnopharmacology 69:63-71.

90. Raimondi A (1857) Elementos de Botánica aplicada a la medicina y la industria. Lima.

91. Rätsch C (1998) Enzyklopädie der psychoaktiven Pflanzen. AT Verlag, Aarau.

92. Reid W (1993) The Economic Realities of Biodiversity. Issues in Science and Technology 10(2):48-55.

93. Revene Z, Bussmann RW, Sharon D (2008) From Sierra to Coast, Tracing the supply of medicinal plants in northern Peru - A plant collector's tale. Ethnobotany Research \& Applications 6:15-22.

94. Rodriguez J, Pacheco P, Razmilic I, Loyola JI, SchmedaHirschmann G, Theoduloz C (1994) Hypotensive and diuretic effect of Equisetum bogotense and Fuchsia magellanica and micropropagation of $E$. bogotense. Phytotherapy Research 8:157160.

95. Ruiz H (1777-1788) Relación del viaje hecho a los reynos del Perú y Chile. Translated by Schultes ER, Nemry von Thenen de Jaramillo-Arango MJ as "The Journals of Hipólito Ruiz, Timber Press, Portland, 1998.

96. Schjellerup I (2009) Razon de las Especies de la Naturaleza y del Arte del Obispado de Trujillo del Peru del Obispo D. Balazar Martinez Compagñon In: Vergara E, Vásquez R (eds) Medicina Tradicional, Conocimento Milenario. Serie Antropología 1:128152.

97. Schultes RE (1994) Amazonian ethnobotany and the search for new drugs. In Ciba Foundation Symposium, vol. 185, Wiley, Chichester, pp. 106-115.

98. Schultes RE, Raffauf R (1990) The Healing Forest. Dioscorides Press, Portland, OR.

99. Sharon D (1978) Wizard of the Four Winds, A Shaman's Story. Free Press, New York.

100. Sharon D (1980) El Chamán de los Cuatro Vientos. Siglo veintiuno editores, México DF.

101. Sharon D (1994) Tuno y sus colegas, notas comparativas. In: Millones L, Lemlij M (eds) En el Nombre del Señor, Shamanes, demonios y curanderos del norte del Perú. Australis S.A., Lima, pp. 128-147.

102. Sharon D (2000) Shamanismo y el Cacto Sagrado - Shamanism and the Sacred Cactus. San Diego Museum Papers 37.

103. Sharon D (2009) Tuno y sus colegas: Notas comparativas. In Galvez C. (Ed) Medicina Tradicional Conocimiento Milenario. Serie Antropología, no 1. Museo de Arquelogía, Antropología e Historia, Facultad de Ciencias Sociales, Universidad Nacional de Trujillo, pp. 255-267.

104. Sharon D, Bussmann RW (2006) Plantas Medicinales en la Obra del Obispo Don Baltasar Jaime Martínez Compagñon (Siglo XVIII). In: Millones L, Kato T (eds) Desde el exterior, El Perú y sus estudios. Tercer Congreso Internacional de Peruanistas, Nagoya, 2005, UNMSM, Lima, pp. 147-165.

105. Sharon D, Galvez C (2009) La mesa de Leoncio Carrión. In: Galvez C (ed) Medicina Tradicional Conocimiento Milenario. 
Serie Antropología, no 1. Museo de Arquelogía, Antropología e Historia, Facultad de Ciencias Sociales, Universidad Nacional de Trujillo, pp. 236-244.

106. Sharon D, Glass-Coffin B, Bussmann RW (2009) La mesa de Julia Calderón de Ávila. In Galvez C (ed) Medicina Tradicional Conocimiento Milenario. Serie Antropología, no 1. Museo de Arquelogía, Antropología e Historia, Facultad de Ciencias Sociales, Universidad Nacional de Trujillo, pp. 245-254.

107. Tilbert JC, Kaptchuk TJ (2008) Herbal medicine research and global health, an ethical analysis. Bulletin of the World Health Organization 86:594-599.

108. United Nations Conference on Trade and Development (2000) Systems and National Experiences for Protecting Traditional Knowledge, Innovations and Practices. Background Note by the UNCTAD Secretariat Geneva, United Nations Conference on Trade and Development, (document reference TD/B/COM.1/ EM.13/2).

109. Van den Eynden V, Cueva C, Cabrera 0 (2004) Of "Climbing Peanuts" and "Dog's Testicles". Mestizo and Shuar plant nomenclature in Ecuador. Journal of Ethnobiology 24(2):279-306.

110. Vandebroek I, Balick MJ, Ososki A, Kronenberg F, Yukes J, Wade C, Jiménez F, Peguero B, Castilloin D (2010) The importance of botellas and other plant mixtures in Dominican traditional medicine. Journal of Ethnopharmacology 128:20-41.

111. Venero B (2005) Componentes de la Diversidad Biológica Peruana Patentados en el Extranjero, La Experiencia de Maca. ¿Cómo combatir la biopiratería? In: Ferro P, Ruiz M (eds) ¿Cómo prevenir la Biopiratería en el Perú? Reflexiones y Propuestas. Lerma Gómez E.I.R.L., Lima, pp. 50-55 and 74-78.

112. Wassen H (1976) Was Espingo (Ispincu) of Psychotropic and Intoxicating Importance for Shamans in Peru? In: Agehananda Bharati (ed) The Realm of the Extra-Human Agents and Audiences. Mouton Publishers, The Hague-Paris. Distributed in the United States and Canada by Aldine, Chicago.

113. Wassen H (1987) "Ulluchu" in Moche Iconography and Blood Ceremonies: The Search for Identification. Göteborg Etnografiska Museum, Annals 1985/86.

114. Weil AT (1978) Coca leaf as therapeutic agent. American Journal of Drug and Alcohol Abuse 5(1):75-86.

115. World Health Organization (1998) Technical Briefing on Traditional Medicine. Forty-ninth Regional Committee Meeting, Manila, Philippines, 18 September 1998, Manila, WHO Regional Office for the Western Pacific.

116. World Health Organization (1999a) Consultation Meeting on TM and Modern Medicine, Harmonizing the Two Approaches. Geneva, World Health Organization, (document reference. (WP)TM/ICP/TM/001/RB/98-RS/99/GE/32(CHN)), World Health Organization, Geneva.

117. World Health Organization (1999b) Traditional, Complementary and Alternative Medicines and Therapies. Washington DC, WHO Regional Office for the Americas/Pan American Health Organization (Working group OPS/OMS).

118. World Health Organization (2002a) Implementation of the WHO Strategy for Prevention and Control of Chronic Respiratory Diseases. WHO/MNC/CRA/02.2, World Health Organization, Geneva.

119. World Health Organization (2002b) WHO Traditional Medicine Strategy 2002-2005. World Health Organization, Geneva.

120. World Health Organization (2002c) Foodborne disease. World Health Organization, Geneva.
121. World Health Organization (2005) Urinary Tract Infections in infants and children in developing countries in the context of IMCI. World Health Organization, Geneva.

122. World Health Organization (2007) Sexually transmitted infections fact sheet. World Health Organization, Geneva.

123. World Health Organization (2009a) Declaración de Alma Ata. World Health Organization, Geneva.

124. World Health Organization (2009b) World health fact sheet. World Health Organization, Geneva.

125. Zamora Pérez DI (2007) Creación de un Órgano Administrativo Especializado en imponer sanciones a los concesionarios mineros en caso de incumplimiento de sus obligaciones ambientales. Tesis de Abogado Universidad Privada Antenor Orrego, Trujillo, Perú.
Received: 01 February 2014

Accepted: 29 April 2014

Published: 12 June 2014 